\title{
WestVirginiaUniversity
}

THE RESEARCH REPOSITORY @ WVU

Graduate Theses, Dissertations, and Problem Reports

2002

\section{Stress response genes in the human proximal tubules}

Doyeob Kim

West Virginia University

Follow this and additional works at: https://researchrepository.wvu.edu/etd

\section{Recommended Citation}

Kim, Doyeob, "Stress response genes in the human proximal tubules" (2002). Graduate Theses,

Dissertations, and Problem Reports. 1629.

https://researchrepository.wvu.edu/etd/1629

This Dissertation is protected by copyright and/or related rights. It has been brought to you by the The Research Repository @ WVU with permission from the rights-holder(s). You are free to use this Dissertation in any way that is permitted by the copyright and related rights legislation that applies to your use. For other uses you must obtain permission from the rights-holder(s) directly, unless additional rights are indicated by a Creative Commons license in the record and/ or on the work itself. This Dissertation has been accepted for inclusion in WVU Graduate Theses, Dissertations, and Problem Reports collection by an authorized administrator of The Research Repository @ WVU.

For more information, please contact researchrepository@mail.wvu.edu. 


\author{
Doyeob Kim \\ Dissertation submitted to the \\ College of Agriculture, Forestry and Consumer Sciences \\ at West Virginia University \\ in partial fulfillment of the requirements \\ for the degree of \\ Doctor of Philosophy \\ in \\ Genetics and Developmental Biology \\ Dr. Donald A. Sens, Committee Co-Chairperson \\ Dr. Joginder Nath, Committee Co-Chairperson \\ Dr. Mary A. Sens \\ Dr. Scott H. Garrett \\ Dr. John Killefer
}

Genetics and Developmental Biology

Morgantown, West Virginia

2002

Keywords: Human proximal tubules, Kidney, Stress Response, Metallothionein, Heat Shock

Copyright 2002 Doyeob Kim 


\section{ABSTRACT \\ Stress Response Genes in the Human Proximal Tubules \\ Doyeob Kim}

The heat shock proteins (hsps) are believed to provide protection against a variety of insults such as elevated temperature, heavy metals and chemical agents. The goal of this study was to determine if the immortalized HK-2 human proximal tubule cell line could provide a model system to study the stress response of the proximal tubule cell. Heat stress, elevated temperature at 42.5 - $\mathrm{C}$ for $1 \mathrm{hr}$, caused a marked increase only in hsp $70 \mathrm{mRNA}$ and protein, but not that of hsp 27 or hsp 60 mRNA and protein. Similar results were obtained when the cells were subjected to $100 \mu \mathrm{M}$ sodium arsenite or $53.4 \mu \mathrm{M} \mathrm{CdCl}_{2}$ for $4 \mathrm{hrs}$. These findings were in contrast to those found previously with mortal human proximal tubule (HPT) cells, where acute stress by all three stimuli elicited marked increases in hsp 27, hsp 60 and hsp 70 mRNA and protein. The basal levels of expression of hsp 27 and hsp 60 in the HK-2 cells were elevated compared to unstressed HPT cells. These results suggest that failure of HK-2 cells to increase hsp 27 and hsp 60 levels in response to stress is because of their elevated basal levels, indicating that the genetic events that resulted in the immortalization of the HK-2 cells also elicited a stress response for hsp 27 and hsp 60, but not for hsp 70. Thus, there are differences in the regulation of the stress response between the immortal HK-2 and mortal HPT cell lines, and as long as these differences are recognized, the HK-2 cell line should be a valuable adjunct to study the stress response of the proximal tubule in general and when exposed to environmental pollutants such as cadmium.

The metallothoneins (MT) are a family of cysteine-rich, low molecular weight $(6 \mathrm{kD})$, intracellular proteins that bind transitional metals. The goal of this study was to further characterize the basal expression of MT-3 in the in situ human kidney, in mortal human proximal tubule (HPT) cell cultures and the immortalized proximal tubular cell line, HK-2. MT-3 mRNA was detected in the 
proximal tubule of the in situ kidney with relative expression in excess to that of the $\exists$-actin housekeeping gene. Human proximal tubule cells also expressed both MT-3 mRNA and protein, and were able to form domes. Exposure of HPT cells to $\mathrm{Cd}^{+2}$ resulted in a transient increase in MT-3 mRNA and protein. In contrast, the HK-2 cell line did not express MT-3 and did not form domes. Stable transfection of the HK-2 cell line with the pcDNA3.1/Hygro(+) vector containing the MT-3 gene restored MT-3 expression and dome formation to the HK-2 cells. This result demonstrated that MT-3 is involved in the transport function of a human renal cell line that retains properties of the proximal tubule. 


\section{DEDICATION}

The author wishes to dedicate this work in appreciation to the many excellent teachers that he has had throughout the course of his education. $\mathrm{He}$ especially expresses his thankfulness to his beloved wife who solely supports, Seung Kyung; his parents, Sung Ye and Won Kyung Kim; his parents-in-law, Yon Soo and Moon Sun Hong; his lovely children, Dong Hyun and Jessica; his sister, Ji Eun; and his graduate fellows. He is so grateful to those named and unnamed who continue to foster his enduring curiosity. 


\section{ACKNOWLEDGEMENTS}

The author wishes to thank:

Dr. Joginder Nath, chairperson of Program of Genetics, for admitting me to study Genetics.

Dr. Scott H. Garrett for his unceasing concern about my work.

Dr. John Killefer for his kind instruction.

Dr. Seema Somji for her assistance to me in the laboratory.

Dr. Mary Ann Sens for her exceptional talent as a pathologist and researcher.

Dr. Donald A. Sens for his encouragement and concern as my research advisor. 


\section{TABLE OF CONTENTS}

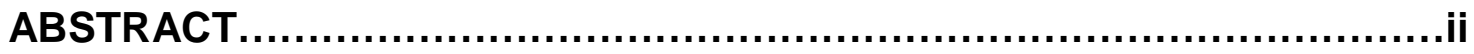

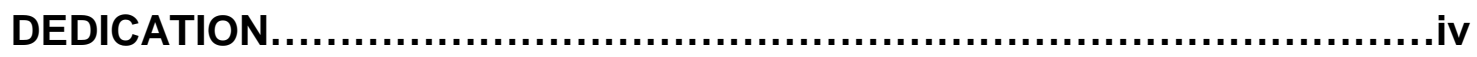

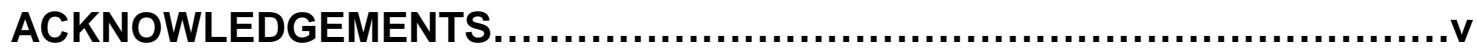

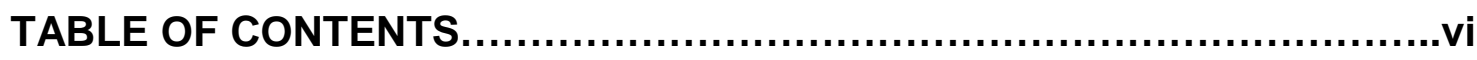

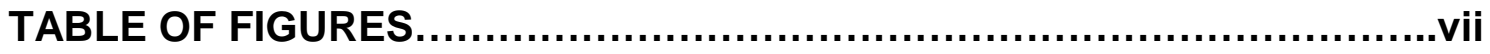

INTRODUCTION AND REVIEW OF LITERATURE................................

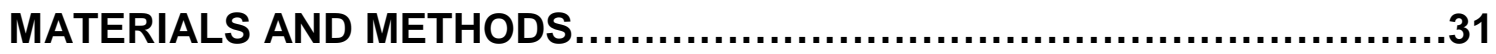

EXPRESSION OF HSP 27, HSP 60, HSC 79 AND HSP 70 BY IMMORTALIZED HUMAN PROXIMAL TUBULE CELLS (HK-2) FOLLOWING EXPOSURE TO HEAT SHOCK, SODIUM ARSENITE, OR CADMIUM CHLORIDE.................50

TRANSIENT INDUCTION OF METALLOTHIONEIN ISOFORM 3 (MT-3), CFOS, C-JUN AND C-MYC IN HUMAN PROXIMAL TUBULE CELLS EXPOSED TO

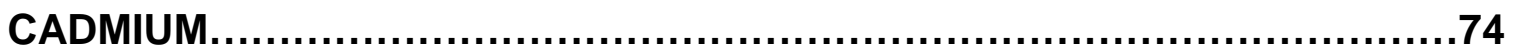

METALLOTHIONEIN ISOFORM 3 AND VECTORIAL ACTIVE TRANSPORT IN HUMAN PROXIMAL TUBULES...................................................106

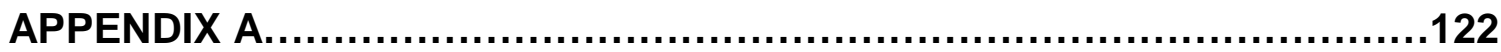

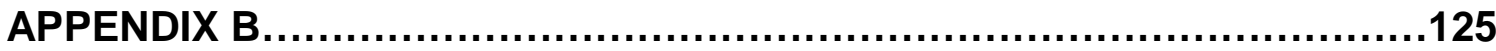

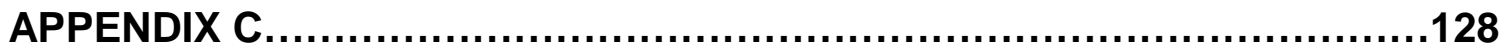




\section{TABLE OF FIGURES}

Figure 1. Expression of hsp 27 mRNA and protein in HK-2 cells acutely exposed to heat shock, sodium arsenite, or $\mathrm{CdCl}_{2}$

Figure 2. Two-dimensional gel electrophoresis of heat-shocked HK-2 cells during exposure and recovery periods.

Figure 3. Expression of hsp 60 mRNA and protein in HK-2 cells acutely exposed to heat shock, sodium arsenite, or $\mathrm{CdCl}_{2}$

Figure 4. Expression of hsc $70 \mathrm{mRNA}$ and protein in HK-2 cells acutely exposed

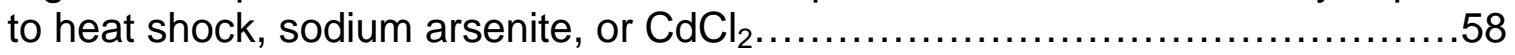

Figure 5. Western analysis of hsp 70 protein in HK-2 cells.......................59

Figure 6. RT-PCR analysis of hsp 70 mRNA in HK-2 cells......................60

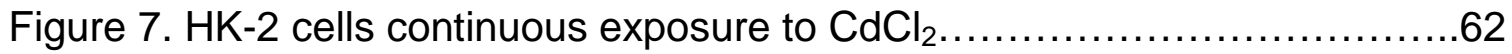

Figure 8. Expression of heat shock proteins in HK-2 cells continuously exposed to $0.9,2.2$, and $4.5 \mu \mathrm{M} \mathrm{CdCl}_{2}$ for a period of 16 days.............................63

Figure 9. Expression of hsp mRNAs in HK-2 cells continuously exposed to 0.9,

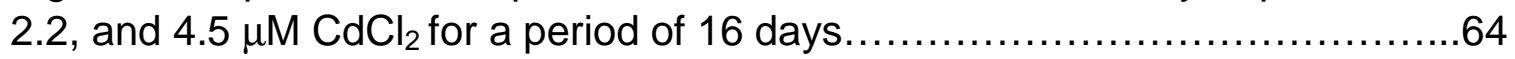

Figure 10. Expression of hsp mRNAs in HK-2 cells continuously exposed to 0.9,

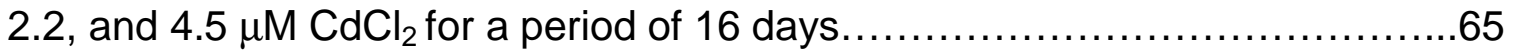

Figure 11. Microdissection of human proximal tubules from adult kidney.........77

Figure 12. Basal expression of MT-3 in human proximal tubule..................78

Figure 13. Expression of MT-3 as a function of cell growth...................... 80

Figure 14. Expression of MT-3 in HPT cells acutely exposed to $\mathrm{Cd}^{+2} \ldots \ldots \ldots \ldots . . . .82$

Figure 15. Expression of MT-3 in HPT cells exposed to $\mathrm{Cd}^{+2}$ for 48 hours.......84

Figure 16. Expression of MT-3 in extended exposure to $\mathrm{Cd}^{+2} \ldots \ldots \ldots \ldots \ldots \ldots . . . \ldots 5$

Figure 17. Expression of $c$-fos, $c$-jun, and $c$-myc in HPT cells acutely exposed to

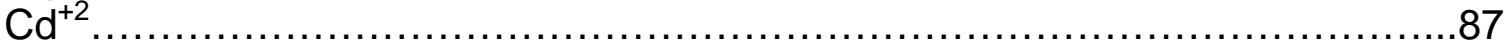


Figure 18. Expression of $c$-fos, $c$-jun, and $c-m y c$ in HPT cells exposed to $\mathrm{Cd}^{+2}$ for 48 hours.

Figure 19. Expression of $c$-fos, $c$-jun, and $c$-myc in extended $\mathrm{Cd}^{+2}$ exposure of HPT cells.

Figure 20. Expression of $c$-fos, $c$-jun, and c-myc in HK-2 cells acutely exposed to $\mathrm{Cd}^{+2}$

Figure 21. Expression of $c$-fos, $c$-jun, and $c-m y c$ in HK-2 cells exposed to $\mathrm{Cd}^{+2}$ 92

Figure 22. Inhibition of HPT cell growth by MT-3 antisense oligonucleotide.....109

Figure 23. RT-PCR analysis of MT expression in HK-2 cell line. 111

Figure 24. Overexpression of MT-3 mRNA and protein in HK-2 cell line. 113

Figure 25. Light level morphology of HK-2 cells with and without MT-3 expression. 114

Figure 26. MT-3 expression and dome formation in MT-3 transfected clones...115 
INTRODUCTION AND REVIEW OF LITERATURE 
A variety of stresses can be divided into 3 categories; Environmental (heat shock, UV irradiation, and toxic chemicals), physiological (metabolic state, $\mathrm{pH}$, redox state) and pathological (infection, inflammation, tissue injury and cancer) stresses. Heat shock proteins (HSPs) and metallothioneins (MTs) are some of the major stress response proteins in cells that function for the protection against most of the stresses. The human kidney, especially the proximal tubule (PT), is one of the most susceptible sites to chronic exposure of cadmium $\left(\mathrm{Cd}^{+2}\right)$. However, the role of the stress response proteins for renal cells against nephrotoxicity has yet to be performed, especially using human proximal tubule cell culture. The overall goal of this project was to elucidate the expression and functions of the two major stress response systems, Hsps and MTs in the human proximal tubule cells using cell culture technique.

The hsps are members of a large superfamily of stress response proteins with molecular mass ranging from 8 to $170 \mathrm{kD}$, with the members referred to as hsp 27, hsp 60, hsc 70 (constitutive form), hsp 70 (inducible form), and hsp 90 being the proteins classically identified to be induced as a result of heat treatment of human cells. In mammalian cells, the synthesis of hsps is induced not only by heat, but also by a variety of stimuli, such as heavy metals, cytotoxic drugs, glucose deprivation, and virus infection (1).

The hsps are known to be involved in protein-protein interactions such as synthesis, assembly and disassembly, translocation, folding, stabilization, prevention of aggregation, and secretion (2). They also have been implicated in the regulation of other important cell functions, such as signal transduction, 
proliferation and apoptosis $(4,5)$, and differentiation. In mammals, hsp 27, which belongs to small hsps, resides in the cytosol and confers thermotolerance by stabilization of microfilaments (6). Hsp 60, mainly located in the mitochondria, refolds aggregates of denatured protein and helps protein degradation in proteolytic systems (7). Hsp 70 and hsc 70 in the cytosol or the nucleus interact with newly synthesized polypeptides, act in signal transduction, and have antiapoptotic activity by binding to apoptosomes (complex of Apaf-1, cytochrome c and pro-caspase 9) (8, 9). Hsp 90 interacts with steroid hormone receptors, tyrosine kinases, and serine/threonine kinases in the cytosol and is involved in cell cycle and proliferation $(10,11,12)$.

In eucaryotes, heat shock factors (HSF) are the major transregulatory proteins in the regulation of hsp genes, which recognize the heat shock elements (HSEs) located in the hsp gene promoters (13). There are at least four HSFs (HSF1 HSF4) isolated from the human (14). Most HSFs contain a conserved DNA-binding domain (helix-turn-helix) located near the N-terminus, three leucine zippers involved in trimerization of the factor, an additional leucine zipper at the C-terminus except for HSF4 inhibiting trimerization of the factor, and some transactivational domains at the end of C-terminus (15). HSF1 and 3 have their primary role in the stress-induced expression of hsp genes (16). HSF2 is activated during specific stages of development and differentiation (26). HSF4 is expressed in some specific tissues, has constitutive DNA binding activity, and acts as a negative regulator of hsp expression (17). HSF1 is located in the cytoplasm as an inactive monomer, bound to Hsp 70 and other chaperones 
under normal conditions. HSF1 is activated when non-native proteins appear as a result of stress. HSF1 monomers translocate to the nucleus, oligomerize to a trimeric state to be phosphorylated, and bind to HSE located upstream of hsp genes, inducing transcriptional activation and synthesis of heat shock proteins. As the HSPs accumulate in the cytoplasm after stress has abated, some chaperones relocalize to the nucleus and bind to HSF1 to repress hsp gene transcription and to dissociate trimers, thereby changing the HSF1 state to the inactive monomers (18).

It has been demonstrated that exposure of cells to a variety of stresses activates some major signaling pathways in which hsps are involved. A variety of stresses can produce denatured or misfolded proteins which trigger the activation of HSF-1 in the nucleus. Hsp 70 can refold the misfolded proteins in the cytosol. UV irradiation can directly induce DNA damage which activates apoptotic cell death involving cytochrome c release from mitochondria and caspase. Hsp 70 has been shown to negatively regulate apoptosis mediated by apoptosomes (19). DNA damage can also activate Fas/FasL ligand, inducing caspase-dependent apoptotic pathway without cytochrome c release from mitochondria. Stress can switch inactive p53 to its active form, thereby inhibiting the trascription of early response genes. Stress such as $\mathrm{Cd}^{+2}$ also increases reactive oxygen species (ROS) which cause the release of cytochrome $c$ from mitochondria, thereby activating downstream caspases. Hsp 27 was shown to control the signaling pathways which ROS activate (20). Some stresses may also activate stressactivated protein kinases (SAPKs) or c-Jun n-terminal kinases (JNKs) which 
induce the caspase-dependent apoptotic pathway. Hsp 70 was suggested to down-regulate the activation of these kinases (21). From these studies, it has been shown that hsps are involved in the negative regulation of apoptotic cell death. There might be some checkpoints where the cells repair damage or undergo apoptotic or necrotic cell death. At these points, the heat shock response can act as a cytoprotectant. If cells have a low level of damage, the heat shock response is activated and protects cells until they restore the normal conditions. However, high level of hsps having protective effects on cell death may affect tumorigenesis (22). That is, excessive down-regulation of apoptosis by aberrant hsp expression can cause transformation of normal cells (23). A wide range of tumors has been shown to overexpress hsps (24), suggesting that hsps may be useful biomarkers. The abnormally high expression of hsps in cancer cells may switch the normal functions of some transcription factors and proteins involved in cell growth, differentiation, and apoptosis to altered functions.

Two environmental toxicants are dealt with in this study; arsenite and cadmium. Arsenic is a human carcinogen. The trivalent form of arsenic, arsenite, is very toxic in humans (25). Arsenite is subject to methylation mainly in the human liver by S-adenosyl-methionein (SAM) as a cofactor and methyltransferases. A suggested mechanism of arsenic carcinogenesis is that excessive amounts of arsenite can cause methyl group depletion, inducing DNA hypomethylation in the cell (26). DNA hypomethylation enhances aberrant gene expression, thereby facilitating transformation of normal cells. 
Cadmium, a widely distributed environmental pollutant, is highly toxic (38). Acute exposure to $\mathrm{Cd}^{+2}$ induces hepatic, pulmonary injury, and chronic exposure produces renal and bone injury (27). It has been known that $\mathrm{Cd}^{+2}$ and other metals activate transcription of hsps. Although the mechanism is still unclear, reactive oxygen species (ROS) generated by $\mathrm{Cd}^{+2}$ can induce hsps transcription (28). The ROS may activate some signal transduction system phosphorylating or dephosphorylating heat shock factors (HSF) or other unknown factors which are related to the activation of hsp expression (29). It was also found that in addition to the heat shock elements (HSEs) as the binding targets for HSF, other transcription elements such as TATA, GC, and CCAAT boxes where multiple transcription factors bind are important in the regulation of the heat shock genes (30).

Most studies so far have been performed with the roles of hsps in proteinprotein interaction, signal transduction and so on. However, since there are a very limited number of studies on mediating cell protection against environmental insults, it would be valuable to study the function of hsps as possible mediators in human cadmium-induced nephrotoxicity using human proximal tubule (HPT) cells which are the primary sites of damage following chronic exposure to environmental cadmium. It would be valuable to study the pattern of hsp expression and regulation using normal HPT cells. But, to define the role of a particular hsp in the protection of HPT against $\mathrm{Cd}^{+2}$, the appropriate experimental design would be to overexpress a hsp gene of interest under the control of strong and constitutive promoter by stable transfection of immortal cells. If the cells 
overexpressing a specific hsp gene confer resistance to the lethal effect of $\mathrm{Cd}^{+2}$, the hsp is involved in the protection of cells from $\mathrm{Cd}^{+2}$-induced toxicity. Rather than mortal HPT cells, the HK-2 cell line derived from the primary HPT cells and immortalized by transfection with the HPV $E_{6} / E_{7}$ genes will be a better choice for this study (31). This cell line has been shown to be immortal, non-tumorigenic, to have most of the biochemical characteristics that HPT possesses, and to produce monolayer cell cultures that retain many features expected of welldifferentiated proximal tubule cells.

The MTs consist of 60 to 68 amino acid residues, among them 20 Cys, arranged to bind a total of 7 equivalents of mono- $\left(\mathrm{Pt}^{+}, \mathrm{Ag}^{+}, \mathrm{Cu}^{+}\right), \mathrm{bi}-\left(\mathrm{Zn}^{+2}, \mathrm{Cd}^{+2}\right.$, $\left.\mathrm{Hg}^{+2}, \mathrm{~Pb}^{+2}, \mathrm{Ni}^{+2}, \mathrm{Co}^{+2}\right)$, and trivalent $\left(\mathrm{Sb}^{+3}, \mathrm{Bi}^{+3}\right)$ metal ions. Their molecular weight range is 6-7 kDa. MTs have two globular metal-binding domains, $\alpha$ (Cterminal region) and $\beta$ ( $\mathrm{N}$-terminal region). MTs have been shown to be involved in metal homeostasis during growth and development (32) such as for zinc $\left(\mathrm{Zn}^{+2}\right)$ and copper $\left(\mathrm{Cu}^{+}\right)$, in the detoxification of heavy metals such as cadmium $\left(\mathrm{Cd}^{+2}\right)$ and mercury $\left(\mathrm{Hg}^{+2}\right)(33,34)$, and in scavenging reactive oxygen species such as hydroxyl radicals $(35,36)$. Some studies suggest that MTs can play a role in tumor cell resistance to chemotherapy (37), in supplying $\mathrm{Zn}^{+2}$ to zinc-finger transcription factors, as tumor proliferation markers (38), and as possible modulators of immune function (39).

There are four families of MT genes: MT-1, MT-2, MT-3, and MT-4. Most cells express constitutive levels of MT, although they vary with cell type (40), and differential expression of human MT isoforms can be detected in various cell 
types (40). The MT-1 and MT-2 isoforms are the ubiquitously expressed isoforms in different tissues. The human MT-3 and MT-4 genes are within $85 \mathrm{~kb}$ of the other MT genes on human chromosome $16(41,42)$. MT-3 is preferentially expressed in the brain (41). However, it has also been detected in the maternal deciduum, reproductive tissues, stomach, heart, and kidney $(43,44)$. The mouse and human MT-4 genes have been cloned and the expression of the genes is likely to be restricted to squamous epithelial cells (42).

MT plays a primary role in metal detoxicification. MTs can hold up to 7 metal ions. The metal binding may stabilize the overall structure of MTs, preventing the susceptibility to proteolysis. The order of the binding affinity of several bivalent metal ions for MT is $\mathrm{Zn}^{+2}<\mathrm{Pb}^{+2}<\mathrm{Cd}^{+2}<\mathrm{Hg}^{+2}$ (45). MTs primarily bind zinc under physiological conditions, but they have a high affinity for potentially toxic heavy metals. Exposure to heavy metals leads to a significant increase of MT expression in most tissues such as liver and kidney (46). This induction is mediated by the metal transcription factor- 1 (MTF-1). MTF-1 is a ubiquitously expressed 69 to $80-\mathrm{kDa}$ protein that is necessary for MT expression (47). The N-terminus of MTF-1 has 6 zinc fingers of cysteine ${ }_{2}$-histdine ${ }_{2}$ type that possess the DNA-binding activity and the C-terminus contains three transcriptional activation domains such as an acidic activation domain and a proline-rich region, and a serine-threonine-rich domain which is a potential phosphorylation region. The binding targets for MTF-1 are metal-responsive elements (MREs) (48). General cis-acting elements in MT promoter are six metal regulatory elements (MREa MREf), MRE-c', GC box (Sp1 binding site), 
glucocorticoid response element (GRE), antioxidant response element (ARE), and locus control region (LCR). MREs and ARE are involved in basal, heavy metal-induced and oxidative stress-induced MT expression. MRE-d has been demonstrated to confer the most effective metal responsiveness of all the six MREs (49). MRE-c' and GC box (by Sp1) are for the basal expression of MT, GRE for glucocorticoid-induced MT expression, and LCR for the MT regulation at the chromatin level. Each element has the binding site for the different transcription factors. MTF- $1^{-/-}$mice, homozygous for MTF-1 deletion, did not survive more than two weeks post-implantation (50). On the contrary, MT-1 and MT-2 knockout mice seemed to be normal. Therefore, MTF-1 plays a more important role in the development than MTs.

Several lines of evidence suggested that the mechanisms of $\mathrm{Zn}^{+2}$ and other heavy metals to up-regulate MT expression via MTF-1 transactivation are somewhat different. Zinc treatment rapidly increased MTF-1 DNA binding activity (51), which suggests that DNA binding of MTF-1 is regulated allosterically by binding of zinc for MTF-1 to increase MT gene expression. Heavy metals $\left(\mathrm{Pb}^{+2}\right.$, $\mathrm{Cu}^{+}$, and $\mathrm{Hg}^{+2}$ ) can activate MTF-1 DNA binding activity by displacing zinc from zinc pool or ZnMT, and subsequently released zinc activates DNA binding of MTF-1. However, It was found that $\mathrm{Cd}^{+2}$ has no effect on the DNA binding activity of MTF-1 (52). Rather, $\mathrm{Cd}^{+2}$ may stimulate kinases to activate MTF-1 by phosphorylation. (53), that is, the metal can phosphorylate MTF-1 to increase its transactivation potential by activating a signalling pathway including protein kinase $\mathrm{C}$, C-Jun $\mathrm{N}$-terminal kinase, phosphoinositol-3 kinase and tyrosine protein 
kinase (54). Phosphorylated MTF-1 induces MT gene expression by binding to MREs.

It was reported that cadmium-resistant cell lines expressing high levels of MT exhibited high resistance to the toxicity of other metals (55). Pretreatment of rat hepatocytes with zinc increased protection against the toxic effects of heavy metals through increased MT expression (56). MT-1 overexpressing mice showed more tolerance to hepatotoxicity resulting from cadmium treatment than control mice (57). In addition, there was an increasing susceptibility to $\mathrm{Cd}^{+2}$ induced liver injury in MT-null mice (58). These reports demonstrated that MT provides a protective effect against $\mathrm{Cd}^{+2}$ toxicity, and the function of MT in metal detoxicification might be due to its capability for metal sequestration.

There is a theory how $\mathrm{Cd}^{+2}$ generates nephrotoxicity (59). $\mathrm{Cd}^{+2}$ can bind to MT and be sequestered in the liver with the form of CdMT where it is initially taken up. Some CdMTs leak into the plasma and then are absorbed by the kidney. $\mathrm{Cd}^{+2}$ is released in the lysosomes of the kidney and can bind to MT in the cytosol. However, nephrotoxicity is induced when critical amounts of $\mathrm{Cd}^{+2}$ accumulate in the cytosol of the kidney.

MTs are induced by radiation, hyperoxia, ethanol, and tert-butyl hydroperoxide, as a free radical scarvenger $(60,61)$. The sensitivity of cells was enhanced by oxidative stress when the metallothionein-deficient cells were exposed to anticancer drugs or cadmium, and overexpression of metallothionein alleviated the sensitivity of cells to free radicals (62). The mechanism of acute cadmium toxicity may involve several aspects including oxidative damage and 
aberrant gene expression,and MT null state aggravates $\mathrm{Cd}^{+2}$-induced abnormal gene expression (63). It implies that MTs may act as an antioxidant. However, the mechanism by which MT protects against oxidative stress is still unclear. It has been suggested that the thiolate clusters of MT are the binding sites for hydroxyl radicals (64). Reduced glutathione (GSH) has less effect on the reduction in lipid peroxidation, an indicator of oxidative damage, than MT does (65). However, during oxidative stress, increased amount of oxidized glutathione (GSSG) releases zinc from ZnMT to apometalloproteins and zinc-finger proteins, such as MTF-1, thereby activating the expression of proteins, such as MTs. Therefore, switch of redox status of cells by oxidative stress can regulate MT gene expression. In addition, free radicals were shown to interact with MTs to release $\mathrm{Zn}^{+2}$ and influence redox state (66). Although Apo-MT which released $\mathrm{Zn}^{+2}$ from $\mathrm{ZnMT}$ as a result of oxidative stress is destined to degradation, free $\mathrm{Zn}^{+2}$ can activate MTF-1 followed by induction of new MTs (67).

MT overexpression was shown to protect the heart muscle cells in mice from the cardiotoxicity of doxorubicin, an anticancer drug (68). It was suggested that the protection of cardiac cells by MTs results from MTs scavenging ROS produced by the metabolism of doxorubicin and causing lipid peroxidation and other oxidative damage in the cardiac cells.

MTs are found in the nucleus during the $S$ phase and mRNA of the MT-I isoform can be located in the vicinity of the nucleus. The translocation mechanism of MTs into the nucleus is mysterious, because MTs do not possess a nuclear localizing signal. The 3'-UTR (untranslated region) of MT mRNA is 
thought to be associated with the perinuclear cytoskeleton (69). In other words, MT protein is synthesized by polyribosomes closely located near the perinuclear cytoskeleton and transported into the nucleus. It is proposed that MTs in the cytosol may play a role in metal detoxification and protection from oxidative stress, whereas MTs in the nucleus may be involved in protection against DNAdamaging electrophiles. MTs offer protection from DNA damage resulting from UV light, suggesting the role of MTs in scavenging free radicals produced by UV radiation and its localization in the nucleus when there is a DNA damage (70). However, the relationship between MT localization and functions of MT should be more clarified.

As for the function of MT in homeostasis of the essential metals, $\mathrm{Zn}^{+2}$ and $\mathrm{Cu}^{+}$are the major metals which bind to MT. MT-1 overexpressing transgenic mice are more resistant to zinc deficiency (71), and kidney development in the MT-null mice was impaired when they were fed a $\mathrm{Zn}$-deficient diet (72). These reports suggest that MTs play a role in maintaining Zn homeostasis. However, MT-null mice appear to live normally, there is still a remaining question whether MT has a direct physiological role in zinc homeostasis. When a high amount of zinc is absorbed into the cells, zinc can induce MT expression via MTF-1 activation. The induced MT binds the absorbed free zinc, which reduces the amount of free zinc to induce more MTs. Then, MT returns to basal level. However, if zinc is deficient in the cells, MT might be degraded to release zinc to the cytosol. The free zinc will be used for zinc-dependent gene regulatory proteins (73). So zinc transfer from MT appears to depend on the specific needs 
of cells or animals and zinc can be utilized for metabolic processes, stored in new tissues, or excreted. This theory is related to the function of MT in the homeostatic regulation of zinc metabolism. There are a mumber of cellular proteins that require zinc for their biological activity. It includes DNA and RNA polymerases, some transcription factors such as zinc-finger proteins. MTs regulate their functions by switching from zinc donor to zinc recipient (apo-MT) or vice versa. For example, the DNA binding activity of zinc-finger transcription factors such as TFIIIA and Sp1 is known to be inactivated by Apo-MT (74).

The homeostatic regulation of copper metabolism by MT in liver was similar to that of zinc metabolism (75). When copper is absorbed from the intestine and transported to the liver, it binds to MT by dispacing zinc in ZnMT. If there is not enough MT available, copper interacts with the trans-acting factors that bind to the MT genes and enhances MT synthesis. The newly synthesized MT binds the excess copper ions. Likewise, the amount of free copper ions is reduced and MT is no longer synthesized.

For the regulation and tissue-expression of MTs, it has been suggested that there are some important components (76): DNAse 1 hypersensitive (HS) sites, chromatin structure, and methylation at the $5^{\prime}$ position of cytosine in CpG dinucleotides. It was shown that some DNAse $1 \mathrm{HS}$ sites are located $7 \mathrm{~kb}$ downstream of MT-1 gene and $10 \mathrm{~kb}$ upstream of MT-2 gene that provide tissuespecific expression. Deacetylation of histones can help the stabilization of nucleosomes or formation of condensed chromatin structures, whereas acetylation of histones may open the condensed chromatin structure. The 
regulation of chromatin structure by histone acetylation/deacetylation probably controls DNAse $1 \mathrm{HS}$ sites in MTs and other proteins as well. It was demonstrated that some inducers of MT-1 could produce DNAse 1 HS sites within MREs of MT-1 promoter and also form active chromatin structure to help MTF-1 bind to MREs. Methylation of CpG islands is related to gene silencing and has an effect on development, inactivation of $\mathrm{X}$ chromosome, and silencing of tissue-specific genes (77). Generally, methyl-CpG islands in a promoter can inhibit the binding of transcription factors to the promoter and suppression of gene expression by methylation of $\mathrm{CpGs}$ requires methyl-CpG binding proteins (MeCPs). Methylation of $\mathrm{CpG}$ islands is probably due to the presence of DNAmethyltransferase (DNA-MTase). It was shown that methylation of different MREs differentially affected binding of MTF-1 (78). In addition, it was suggested that methylation of $\mathrm{CpG}$ islands alters chromatin structure by positioning nucleosomes on the MT promoter, inhibiting the binding of transcription factors such as MTF-1 and Sp1 to the promoter (79). Taken together, DNAse 1 hypersensitive (HS) sites, chromatin structure, and methylation in CpG dinucleotides are all important and closely related to each other for the regulation and tissue-expression of MTs.

The proximal tubule absorbs $80 \%$ of bicarbonate, $50 \%$ of $\mathrm{NaCl}$, and most of the organic solutes filtered at the glomerulus (80). One of the characteristics of proximal tubule cells in cell culture is that they are able to form domes. The dome of the cell monolayer is an out-of-focus area, which can be seen upon light microscopic examination. It is a lifting between the epithelial cell monolayer and 
the culture dish, where fluid has been trapped underneath the monolayer owing to active transport of ions and water across the cell monolayer in an apical to basolateral direction (81). Some known requirements of dome formation are functional plasma membrane polarization, formation of occluding junctions (tight junctions), and vectorial transepithelial active ion transport. The dome formation is a hallmark of cultured renal epithelial cells that retain the in situ property of vectorial active transport (82). It was found that ouabain, a $\mathrm{Na}^{+}-\mathrm{K}^{+}$ATPase inhibitor, blocked the formation of domes (83). Therefore, the $\mathrm{Na}^{+}-\mathrm{K}^{+}$ATPase provides a driving force for transepithelial ion and fluid transport.

In order to be differentiated, the proximal tubule cells should generate some of the characteristic functions such as microvilli, occluding junction, cell polarity and active transport. As previously described, most of these functions are the requirements of dome formation, a phenomenon implying that the cells are differentiated, thereby expressing the characteristic functions.

The motivation of this study is based on the facts that the human proximal tubules are the primary site where most toxic substances are absorbed after filtration in the glomerulus of the kidney. Heat shock proteins and metallothioneins are the most important stress response proteins during stress conditions, and that chronic nephrotoxicity occurs when the critical amount of toxic compounds reaches the kidney. This research is especially focused on the MT-3 isoform which has received comparatively more interest due to the fact that it was first identified in a search for a neuronal growth factor whose 


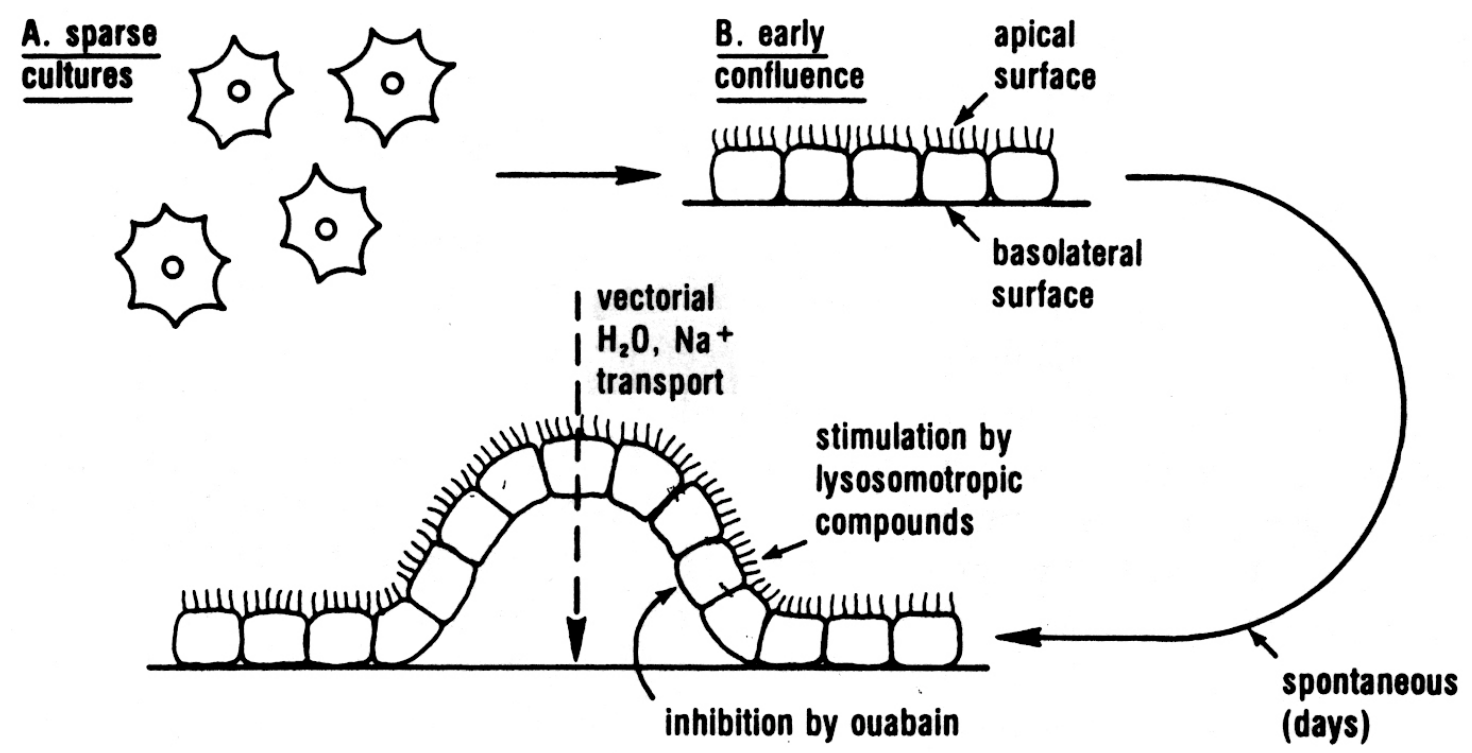

C. dome formation

Adapted from Lever, J. E., Inducers of dome formation in epithelial cell cultures including agents that cause differentiation, Chapter 1. In Tissue Culture of Epithelial Cells, Edited by Taub M, New York, Plenum Press, pp 3-22, 1985. 
dysregulation might be involved in the inappropriate formation of neurofibrillary tangles in brains of individuals with Alzheimer's disease (44). This protein, which was originally called growth inhibitory factor (GIF), was shown to retain all the characteristic features of the traditional MTs and was renamed MT-3 (41). Based on studies in the mouse, MT-3 was designated as a brain-specific MT with expression limited to cells of neural origin (41). In addition to a restricted tissue distribution, there are other features of MT-3 that are unique compared to the highly characterized MT-1 and MT-2 isoforms. At the level of transcription, MT-3 is not inducible by most of the stimuli that normally increase MT-1 and MT-2 gene transcription in liver and brain $(41,84,85)$. There is also evidence that the regulation of tissue-specific MT-3 expression does not involve a repressor and that the metal response elements (MREs), which are the binding targets for the transcription activating factor (MTF-1) are present in the promoter region of the MT-3 gene as well as other MT genes, and are nonfunctional (86). Structurally, the MT-3 isoform possesses 8 additional amino acids that are not present in any other members of the MT gene family, a 6 amino acid C-terminal sequence and two prolines in the $\mathrm{N}$-terminal region $(41,44)$. Functionally, MT-3 has been shown to exhibit a neuronal cell growth inhibitory activity which is not duplicated by the other human MT classes. This non-duplication of function occurs despite a $63-69 \%$ homology in amino acid sequence among MT-3 and the other human MT isoform. There is also evidence to suggest that the interactions with zinc can be different between MT-3 and the other MT isoforms (87). 
The interest of this research in the role of MT-3 in the renal system comes from the unexpected finding that MT-3 mRNA was present in total RNA isolated from human kidney tissue and cell cultures derived from the human proximal tubule (88). That MT-3 protein was expressed in the in situ human kidney was subsequently confirmed by immunolocalization using an antibody directed against the human MT-3 protein (89). Human proximal tubule cell cultures retain many of the structural and functional features of differentiation expected of cells derived from the proximal tubule and could serve as a good model to study $\mathrm{Cd}^{+2}$ induced nephrotoxicity. These cells upon reaching confluency halt proliferation and become highly polarized due to tight junction formation and are capable of vectorial active transport as noted by dome formation (81). The immortal HK-2 cell line which is derived from cultures of HPT cells retains many features of the proximal tubules but lack vectorial active transport (90). The goals of this study were to further characterize the basal expression of MT-3 in the proximal tubules

from the kidney, to determine if MT-3 is induced by $\mathrm{Cd}^{+2}$, if MT-3 is involved in $\mathrm{Cd}^{+2}$ resistance, and if MT-3 participates in the maintenance of the proximal tubule cell function of vectorial active transport.

\section{REFERENCES}

1. Macario, A. J. L. Heat-shock proteins and molecular chaperones; Implications for pathogenesis, diagnostics, and therapeutics. Int. J. Clin. Lab. Res. 25:59-70, 1995. 
2. Craig, E. A., Weissman, J. S, and Horwich, A. L. Heat shock proteins and molecular chaperones: Mediators of protein conformation and turnover in the cell. Cell 78:365-372, 1994.

3. Ciocca, D. R., Oesterreich, S., Chamness, G. C., McGuire, W. L., and Fuqua, S. A. W. Biological and clinical implications of heat shock protein 27000 (Hsp 27): a review. J. Natl. Cancer Inst. 85:1558-1570, 1993.

4. Pechan, P. M. Heat shock proteins and cell proliferation. FEBS Lett. 280:14, 1991.

5. Arrigo, A. P. Small stress proteins: Chaperones that act as regulators of intracellular redox state and programmed cell death. Cell 379:19-26, 1998.

6. Richards, E. H., Hickey, E., Weber, L, and Master, J. R. Effect of overexpression of the small heat shock protein HSP 27 on the heat and drug sensitivities of human testis tumor cells. Cancer Res. 56:2446-2451, 1996.

7. Georgopoulos, C., and Welch, W. J. Role of the major heat shock proteins as molecular chaperones. Ann. Rev. Cell Biol. 9:601-634, 1993.

8. Mosser, D. D., Caron, A. W., Bourget, L., Denis-Larose, C., and Massie, B. Role of the human heat shock protein hsp70 in protection against stressinduced apoptosis. Mol. Cell. Biol. 17:5317-5327, 1997.

9. Beere, H., Wolf, B., Mosser, R., Klein, K., Kuwana, T., Morimoto, R., et al. Heat shock protein 70 (Hsp70) inhibits apoptosis by preventing recruitment of procaspase-9 to aggregated Apaf-1. Nature Cell. Biol. 2: 469-75, 2000. 
10. $\mathrm{Xu}, \mathrm{Y}$. , Singer, M. A., and Lindquist, S. Maturation of the tyrosine kinase ssrc as a kinase and as a substrate depends on the molecular chaperone Hsp90. Proc. Natl. Acad. Sci. USA 96:109-114, 1999.

11. Smith D. F., Whitesell, L., Nair, S. C., Chen, S., Prapapanich, V., and Rimerman, R. A. Progesterone receptor structure and function altered by geldanamycin, an hsp90-binding agent. Mol. Cell. Biol. 15:6804-12, 1995.

12. Scheibel, T., and Buchner, J. The Hsp90 complex - a super-chaperone machine as a novel drug target. Biochem. Pharmacol. 56:675-82, 1998.

13. Wu, C. Heat shock transcription factors: Structure and regulation. Annu. Rev. Cell Dev. Biol. 11:441-469, 1995.

14. Schuetz, T. J., Gallo, G., Sheldon, L., Tempst, P., and Kingston, R. E. Isolation of a cDNA for HSF2 : Evidence for two heat shock factor genes in humans. Proc. Natl. Acad. Sci. USA 88:6911-6915, 1991.

15. Green, M., Schuetz, T. J., Sullivan, E. K., and Kingston, R. E. A heat shockresponsive domain of human HSF1 that regulates transcription activation domain function. Mol. Cell. Biol. 15:3354-3362, 1995.

16. Tanabe, M., Kawazoe, Y., Takeda, S., Morimoto, R. I., Nagata, K., and Nakai, A. Disruption of the HSF3 gene results in the severe reduction of heat shock gene expression and the loss of thermotolerance. EMBO J. 17:1750-1758, 1998.

17. Craig, E. A., Baxter, B. K., Becker, J., Halladay, J., and Ziegelhoffer, T. Cytosolic hsp70s of Saccaromyces cerevisiae: Roles in protein synthesis, 
protein translocation, proteolysis, and regulation. In: The Biology of Heat Shock Proteins and Molecular Chaperones, 1994.

18. Santoro, M. G. Heat shock factors and the control of the stress response. Biochem. Pharmacol. 59:55-63, 2000.

19. Beere, H., Wolf, B., Mosser, R., Klein, K., Kuwana, T., Morimoto, R., et al. Heat shock protein 70 (Hsp70) inhibits apoptosis by preventing recruitment of procaspase-9 to aggregated Apaf-1. Nature Cell. Biol. 2: 469-75, 2000.

20. Richards, E. H., Hickey, E., Weber, L, and Master, J. R. Effect of overexpression of the small heat shock protein HSP 27 on the heat and drug sensitivities of human testis tumor cells. Cancer Res. 56:2446-2451, 1996.

21. Meriin, A. B., Yaglom, J. A., Gabai, V. L., Zon, L., Ganiatsas, S., Mosser, D. D., et al. Protein-damaging stresses activate c-Jun N-terminal kinase via inhibition of its dephosphorylation: a novel pathway controlled by HSP72. Mol. Cell. Biol. 19:2547-55, 1999.

22. Jaattela, M. Escaping cell death: survival proteins in cancer. Exp. Cell Res. 248:30-43, 1999.

23. Stewart, B. W. Mechanism of apoptosis: integration of genetic, biochemical, and cellular indicators. J. Natl. Cancer Inst. 86:1286-96, 1994.

24. Morimoto, R. I. Heat shock: the role of transient inducible responses in cell damage, transformation, and differentiation. Cancer cells 3:295-301, 1991.

25. Zakharyan, R. A., Wildfang, E., and Aposhian, H. V. Enzymatic methylation of arsenic compounds. III. The marmoset and tamarin, but not the rhesus, 
monkeys are deficient in methyltransferases that methylate inorganic arsenic. Toxicol. Appl. Pharmacol. 140:77-84, 1996.

26. Zhao, C. Q., Young, M. R., Diwan, B. A., Coogan, T. P., and Waalkes, M. P. Association of arsenic-induced malignant transformation with DNA hypomethylation and abberant gene expression. Proc. Natl. Acad. Sci. USA 94:10907-12, 1997.

27. Goyer, R. A., and Cherian, M. G. Toxicology of metals: Biochemical aspects. Handbook of experimental pharmacology. Vol. 115. New York: Springer-Verlag.

28. Abe, T., Konishi, T., Katoh, T., Hirano, H., Matsukuma, K., Kashimura, M., and Higashi, K. Induction of heat shock 70 mRNA by cadmium is mediated by glutathione suppressive and non-suppressive triggers. Biochim. Bio 1201:29-34, 1994.

29. Favatier, F., and Polla, B. Tobacco-smoke-inducible human haem oxygenase-1 gene expression: role of distinct transcription factors and reactive oxygen intermediates. 353:475-482, 2001.

30. Hung, J. J., Cheng, T. J., Chang, M. D., Chen, K. D., Huang, H. L., and Lai, Y. K. Involvement of heat shock elements and basal transcription elements in the differential induction of the $70-\mathrm{kDa}$ heat shock protein and its cognate by cadmium chloride in 9L rat brain tumor cells. J. Cell Biochem. 71:21-35, 1998. 
31. Ang, D., Libererk, K., Skowyra, D., Zylicz, M., Georgogpoulos, C. Biological role and regulation of the universally conserved heat shock proteins. J. Biol. Chem. 266: 24233-24236, 1991.

32. Cousins, R. J. Metallothionein-aspects related to copper and zinc metabolism. J. Inherited Metab. Dis. 6:15-21, 1983.

33. Lever, A. P., and Miya, T. S. A mechanism for cadmium- and zinc- induced tolerance to cadmium toxicity: involvement of metallothionein. Toxicol. Appl. Pharmacol. 37:403-414, 1976.

34. Goering, P. L., and Klaassen, C. D. Altered subcellular distribution of cadmium following cadmium pretreatment: possible mechanism of tolerance to cadmium-induced lethality. Toxicol. Appl. Pharmacol. 70:195-203, 1983.

35. Susan, L. A., and Lashitew, G. Molecular analysis of metallothionein gene regulation. Progress in Nucleic Acid Research and Molecular Biology. 59:257-289, 1998.

36. Iszard, M. B., Liu, J., and Klaassen, C. D. Effect of several metallothionein inducers on oxidative stress defense mechanisms in rats. Toxicol. Lett. 104:25-33, 1995.

37. Satoh, M., Cherian, M. G., Imura, N., and Shimizu, H. Modulation of resistance to anticancer drugs by inhibition of metallothionein synthesis. Cancer Res. 54:5255-5257, 1994.

38. Meskel, H. H., cherian, M. G., Martinez, V. J., Veinot, L. A., and Frei, J. V. Metallothionein as an epithelial proliferative compartment marker for DNA flow cytometry. Modern Pathol. 6:755-760, 1993. 
39. Zelikoff, J. T., Smialowicz, R., Bigazzi, P. E., Goyer, R. A., Lawrence, D. A., Malbach, H. I., and Gardner, D. Symposium overview. Immunomodulation by metals. Fund. Appl. Toxicol. 22:1-7, 1994.

40. Palmiter, R. D. Molecular biology of metallothionein gene expression. Experimentia. 52:63-80, 1987.

41. Palmiter, R. D., Findley, S. D., Whitmore, T. E., and Durnam, D. M. MT-III, a brain-specific member of the metallothionein gene family. Proc. Natl. Acad. Sci. USA 89:6333-6337, 1992.

42. Quaife, C. J., findley, S. D., Erickson, J. C., Froelick, G. J., Kelly, E. J., Zambrowicz, B. P., and Palmiter, R. D. Induction of a new metallothionein isoform (MT-IV) occurs during differentiation of stratified squamous epithelia. Biochemistry 33:7250-7259, 1994.

43. Moffatt, P., and Sequin, C. Expression of the gene encoding metallothionein-3 in organs of the reproductive system. DNA Cell Biol. 17:501-510, 1998.

44. Liang, L., Fu, K., Lee, D. K., Sobieski, R. J., Dalton, T., and Andrews, G. K. Activation of the complete mouse metallothionein gene locus in the maternal deciduum. Mol. Reprod. Develop. 43:25-37, 1996.

45. Kagi, J. H., and Kojima, Y. Chemistry and biochemistry of metallothionein. Experientia 52:25-61, 1987.

46. Cherian, M. G., and Goyer, R. A. Metallothioneins and their role in the metabolism and toxicity of metals. Life Sci.23:1-9, 1978. 
47. Heuchel. R., Radtke, F., Georgiev, O, Hergersberg, M., Gariglio, M., Dembic, Z., and Schaffner, W. Cloned transcription factor MTF-1 is essential for basal and heavy metal-induced metallothionein gene expression. EMBO J. 13:2870-5, 1994.

48. Ghoshal, K., and Jacob, S. T. Regulation of metallothionein gene expression. Prog. Nucleic Acid Res. 66:357-85, 2001.

49. Palmiter, R. D. Molecular biology of metallothionein gene expression. Exs 52:63-80, 1987.

50. Gunes, C., Heuchel, O., Georgiev, K. H., Muller, P., et al. Embryonic lethality and liver degeneration in mice lacking the metal-responsive transcriptional activator MTF-1. EMBO J. 17:2846-2854, 1998.

51. Radtke, F., Heuchel, R., Georgiev, O., Hergersberg, M., Gariglio, M., Dembic, Z., and Schaffner, W. Cloned transcription factor MTF-1 activates the mouse metallothionein-I promoter. EMBO J. 12:1355-62, 1993.

52. Koizumi, S., Suzuki, K., Ogra, Y., Yamada, H., and Otsuka, F. Transcriptional activity and regulatory protein binding of metal-responsive elements of the human metallothionein-IIA gene. Eur. J. Biochem. 259:63542, 1999.

53. Bittel, D., Dalton, T., Samson, S. L., Gedamu, L., and Andrews, G. K. The DNA binding activity of metal response element-binding transcription factor1 Is activated in Vivo and in Vitro by zinc, but not by other transition metals. J. Biol. Chem. 173:7127-7133, 1998. 
54. LaRochelle, O., Gagne, V., Charron, J., Soh, J. W., and Seguin, C. Phosphorylation is involved in the activation of metal-regulatory transcription factor 1 in response to metal ions. J. Biol. Chem. 276:41879-88, 2001.

55. Durnam, D. M., and Palmiter, R. D. Induction of metallothionein-I mRNA in cultured cells by heavy metals and iodoacetate: evidence for gratuitous inducers. Mol. Cell. Biol. 4:484-91, 1984.

56. Liu, J., Kershaw, W. C., and Klaassen, C. D. The protective effect of metallothionein on the toxicity of various metals in rat primary hepatocyte culture. Toxicol. App. Pharmacol. 107:27-34, 1991.

57. Liu, Y. P., Liu, J., Iszard, M. B., Andrews, G. K., Palmiter, R. D., Klaassen, C. D. Transgenic mice that overexpress metallothionein-I are protected from cadmium lethality and hepatotoxicity. Toxicol. Appl. Pharmacol. 135:222228, 1995.

58. Masters, B. A., Kelly, E. J., Quaife, C. J., Brinster, R. L., and Palmiter, R. D. Targeted disruption of metallothionein I and II genes increases sensitivity to cadmium. Proc. Natl. Acad. Sci. USA 91:584-588, 1994.

59. Klaassen, C. D., Liu, J., and Choudhuri, S. Metallothionein: An intracellular protein to protect against cadmium toxicity. Annu. Rev. Pharmacol. Toxicol. 39:267-294, 1999.

60. Cai, L., Satoh, M., Tohyama, C., and Cherian, M. G. Metallothionein in radiation exposure: its induction and protective role. Toxicol. 132:85-98, 1999. 
61. Kershaw, W. C., Iga, T., and Klaassen, C. D. Ethanol decreases cadmium hepatotoxicity in rats: possible role of hepatic metallothionein induction. Toxicol. Appl. Pharmacol. 106:448-455, 1990.

62. Lazo, J. S., Kuo, S. M., Woo, E. S., and Pitt, B. R. The protein thiol metallothionein as an antioxidant and protectant against antineoplastic drugs. Chem. Biol. Interact. 111-112:255-262, 1998.

63. Liu, J., Kadiiska, M. B., Corton, J. C., Qu, W., et al. Acute cadmium exposure induces stress-related tene expression in wild-type and metallothionein-I/II-null mice. Free Radic. Biol. Med. 32:525-35, 2002.

64. Thornalley, P. J., and Vasak, M. Possible role for metallothionein in protection against radiation-induced oxidative stress. Biochim. Biophys. Acta 827:36-44, 1985.

65. Miura, T., Muraoka, S., and Ogiso, T. Antioxidant activity of metallothionein compared with reduced glutathione. Life Sci. 60:301-309, 1997.

66. Thomas, J. P., Bachowski, G. J., and Girotti, A. W. Inhibition of cell membrane lipid peroxidation by cadmium- and zinc-metallothioneins. Biochim. Biophys. Acta 884:448-461, 1986.

67. Davis, S. R., and Cousins, R. J. Metallothionein expression in animals: a physiological perspective on function. J. Nutrition 130:1085-88, 2000.

68. Kang, Y. J., Chen, A., Yu, M., and Epstein, P. N. Overexpression of metallothionein in the heart of transgenic mice suppresses doxorubicin cardiotoxicity. J. Clinical Invest. 100:1501-1506, 1997. 
69. Levadoux, M., Mahon, C., Beattie, J. H., Wallace, H. M., and Hesketh, J. E. Nuclear import of metallothionein requires Its mRNA to be associated with the perinuclear cytoskeleton. J. Biol. Chem. 274:34961-34966, 1999.

70. Schwarz, M. A., Lazo, J. S., Yalowich, J. C., et al. Metallothionein protects against the cytotoxic and DNA-damaging effects of nitric oxide. Proc. Natl. Acad. Sci. USA 92:4452-4456, 1995.

71. Dalton, T., Fu, K., Palmiter, R. D., and Andrews, G. K. Transgenic mice that overexpress metallothionein-I resist dietary zinc deficiency. J. Nutr. 126:825-833, 1996.

72. Kelly, E. J., Quaife, C. J., Froelick, G. J., and Palmiter, R. D. Metallothionein I and II protect against zinc deficiency and zinc toxicity in mice. J. Nutr. 126:1782-1790, 1993.

73. Bremner, I. Nutritional and physiologic significance of metallothionein. Methods In Enzymol. 205:25-35, 1991.

74. Zeng, J., Vallee, B. L., and Kagi, J. H. Zinc transfer from transcription factor IIIA fingers to thionein clusters. Proc. Natl. Acad. Sci. USA 88:9984-9988, 1991.

75. Bremner, I. Metallothionein and copper metabolism in liver. Methods in Enzymol. 205:585-591, 1991.

76. Ghoshal, K., and Jacob, S. Regulation of metallothionein gene expression. Prog. Nucleic Acid Res. 66:357-384, 2001.

77. Jaenisch, R. DNA methylation and imprinting: why bother? Trends Genet. 13:323-329, 1997. 
78. Radtke, F., Hug, M., Georgiev, O., Matsuo, K., and Schaffner, W. Differential sensitivity of zinc finger transcription factors MTF-1, Sp1 and Krox-20 to CpG methylation of their binding sites. Biol. Chem. Hoppe Seyler 377:47-56, 1996.

79. Kass, S. U., Pruss, D., and Wolffe, A. P. How does DNA methylation repress transcription? Trends Genet. 13:444-449, 1997.

80. Orson, W. M., Patricia, A. P., and Robert, J. A. Cellular model of proximal tubule $\mathrm{NaCl}$ and $\mathrm{NaHCO}_{3}$ absorption. Kidney Int. 38:605-611, 1990.

81. Lever, J. E. Inducers of dome formation in epithelial cell cultures including agents that cause differentiation, Chapter 1. In Tissue Culture of Epithelial Cells, Edited by Taub M, New York, Plenum Press, pp 3-22, 1985.

82. Sens, D. A., Detrisac, C. J., Sens, M. A., Rossi, M. R., Wenger, S. L., and Todd, J. H. Tissue culture of human renal epithelial cells using a defined serum-free growth formulation. Exper. Nephrol. 7:344-352, 1999.

83. Abaza, N. A., Leighton, J., and Schultz, S. G. Effects of ouabain on the function and structure of a cell line (MDCK) derived from canine kidney. I. Light microscopic observations of monolayer growth. In vitro. 10:172-183, 1974.

84. Kramer, K. K., Zoelle, J. T., and Klaassen, C. D. Induction of metallothionein mRNA and protein in primary murine neuron cultures. Toxicol. Appl. Pharmacol. 141:1-7, 1996.

85. Hernandez, J., Molinero, A., Campbell, I. L., and Hidalgo, J. Transgenic expression of interleukin- 6 in the central nervous system regulates brain 
metallothionein-I and III expression in mice. Mol. Brain Res. 48:125-131, 1997.

86. Faraonio, R., Moffatt, P., LaRochelle, O., Schipper, H. M., S-Arnaud, R., and Sequin, C. Characterization of cis-acting elements in the promoter of the mouse metallothionein-3 gene. Eur. J. Biochem. 267:1743-1753, 2000.

87. Palmiter, R. D. Constitutive expression of metallothionein-III (MT-III), but not MT-1, inhibits growth when the cells become zinc deficient. Toxicol. Appl. Pharmacol. 135:139-146.

88. Hoey, J. G., Garrett, S. H., Sens, M. A., Todd, J. H., and Sens, D. A. Expression of MT-3 mRNA in human kidney, proximal tubule cell cultures, and renal cell carcinoma. Toxicol. Lett. 92:149-160, 1997.

89. Garrett, S. H., Sens, M. A., Todd, J. H., Somji, S., and Sens, D. A. Expression of MT-3 protein in the human kidney. Toxicol. Lett. 105:207-214, 1999.

90. Ryan, M. J., Johnson, G., Kirk, J., Fuerstenberg, S. M., and Zager, R. A., Torok-Storb, B. HK-2: An immortalized proximal tubule epithelial cell line from normal adult human kidney. Kidney Int. 45:48-57, 1994. 
MATERIALS AND METHODS 


\section{CELL CULTURE}

Stock cultures of HPT cells previously isolated by the procedure described by this laboratory were used in the present studies (1). Three isolates of HPT cells were used and these isolates were derived from normal cortical tissue obtained from kidneys removed for renal cell carcinoma. The kidneys were from a 72-year-old female, a 63-year-old male, and a 58-year-old female. Also, stock cultures of the immortalized HK-2 cell line were grown in $75 \mathrm{~cm}^{2}$ T-flasks using the same serum-free growth formulation (2). The formulation of the growth medium consisted of a 1:1 mixture of Dulbecco's modified Eagles' medium (DMEM) and Ham's F-12 growth medium supplemented with selenium $(5 \mathrm{ng} / \mathrm{ml})$, insulin (5 $\mu \mathrm{g} / \mathrm{ml})$, transferrin $(5 \mu \mathrm{g} / \mathrm{ml})$, hydrocortisone $(36 \mathrm{ng} / \mathrm{ml})$, triiodothyronine (4 pg/ml), and epidermal growth factor $(10 \mathrm{ng} / \mathrm{ml})$. The cells were fed fresh growth medium every 3 days and were subcultured at confluence (normally 3-6 days post subculture). To subculture, the culture medium was removed and the flasks were rinsed with $10 \mathrm{ml}$ of sterile PBS. Cells were treated with $3 \mathrm{ml}$ of trypsin-EDTA (Gibco-BRL, Cat No. 25300-062), and the flasks were placed on a $37^{\circ} \mathrm{C}$ hot plate. The cells were trypsinized until they appeared completely dissociated (approximately 10 minutes) and the cell suspension was transferred to a $15 \mathrm{ml}$ conical tube. The flasks were rinsed with $10 \mathrm{ml}$ of PBS, and the wash was added to the tube containing the trypsinized cells. The tube was centrifuged for 5 minutes at $10,000 \mathrm{rpm}$, after which the supernatant was removed and the cell pellet was thoroughly resuspended in $10 \mathrm{ml}$ of medium. Aliquots of $5 \mathrm{ml}$ of cell suspension were transferred to T-75 flasks containing $10 \mathrm{ml}$ of the growth 
medium. Stock cultures of HTP cells and HK-2 cell line were maintained in 75 $\mathrm{cm}^{2}$ T-flasks using the serum-free growth formulation.

\section{LASER CAPTURE MICRODISSECTION}

The PixCell II ${ }^{\mathrm{TM}}$ LCM System (Arcturus Engineering, Mountain View, CA) was used for laser capture. Five $\mu \mathrm{m}$ thick sections were cut from formalin-fixed, paraffin embedded tissue blocks of human kidney obtained from the pathology archives and mounted on plain glass slides. The slides were stained with hematoxylin and eosin. Total RNA was extracted from samples using the micro RNA isolation kit (Stratagene, La Jolla, CA, Catalog No: 200344).

\section{EXPOSURE OF HK-2 CELLS TO HEAT, SODIUM ARSENITE, AND $\mathrm{CdCl}_{2}$ FOR HEAT SHOCK PROTEIN EXPRESSION}

For hsp expression in $\mathrm{HK}-2$ cells, heat, sodium arsenite, and $\mathrm{CdCl}_{2}$ were used as the stress stimuli. T-25 flasks were subcultured at a 1:4 ratio from T-75 flasks of HK-2 cell cultures. The cells were fed with $5 \mathrm{ml}$ of fresh media 24 hours after subculture and every 72 hours for seven days. Excluding the one hour of heat stress, HK-2 cells were maintained at $37^{\circ} \mathrm{C}$ for the duration of the experiment.

A 15 lbs. brick, two plastic baskets were warmed to $44^{\circ} \mathrm{C}$ in a water bath and kept at constant temperature for 30 minutes. During this time, four control flasks were removed from the incubator to obtain RNA and SDS total protein samples. These RNA and SDS total protein control samples were collected into individually labeled tubes and frozen at $-70^{\circ} \mathrm{C}$ before the experiment. 
The temperature dial on the water bath was re-adjusted to $42.5^{\circ} \mathrm{C}$. Quickly, 40 HK-2 cell flasks (two for RNA samples and two for protein samples in ten time courses) were taken from the incubator and the cap of each flask was very securely tightened. The baskets were removed from the water bath and the flasks were carefully arranged in the bottom basket. The second basket was placed on top of the flasks and the brick was placed in the top basket. The flasks were immediately submerged, and the water temperature was monitored at 42.5 $\pm 1^{\circ} \mathrm{C}$ with constant stirring for one hour. The water temperature was initially set at $44^{\circ} \mathrm{C}$ to compensate for the $1.5 \pm 1^{\circ} \mathrm{C}$ lowering in temperature resulting from the addition of the flasks. After one hour at $42.5^{\circ} \mathrm{C}$, the flasks were removed from the water bath and dried by an assistant while four flasks were randomly selected in duplicate, two RNA and two SDS total protein samples. Dried flasks were placed in $37^{\circ} \mathrm{C}$ incubator for a 48 hour recovery period, and RNA and SDS total protein samples were collected after 1, 2, 4, 8, 12, 16, 24, 36 and 48 hours from the recovery. Methods for the isolation of RNA and SDS total protein are described below.

For sodium arsenite exposure, T-75 flasks of HK-2 cell cultures were subcultured at a 1:4 subculture ratio into six-well plates. The cells were fed with 2 $\mathrm{ml}$ of fresh media 24 hours after subculture and every 72 hours until the experiment was initiated when cells were confluent. The final feeding was 24 hours prior to starting the experiment. Cells were maintained in a $37^{\circ} \mathrm{C} \mathrm{CO}_{2}$ incubator for the duration of the experiment. 
A $100 \mu \mathrm{M} \mathrm{NaAsO}$ solution in freshly prepared complete serum-free medium was made just prior to exposing the cells. RNA and SDS total protein samples were obtained in triplicate no more than one hour prior to the start of the experiment. Cells were fed with $2 \mathrm{ml}$ per well with the $100 \mu \mathrm{M} \mathrm{NaAsO} \mathrm{N}_{2}$ solution, and incubated at standard conditions for four hours. RNA and SDS total protein samples were collected in triplicate at one, two and four hours of exposure to sodium arsenite. After four hours of exposure all of the cells were fed with $2 \mathrm{ml}$ of freshly prepared medium and subsequently incubated for 48 hours. RNA and SDS total protein samples were obtained in triplicate for each recovery time point $(4,8,12,16,24,36$ and 48 hours). Both the exposure and the recovery times were plotted from the time the plates entered the incubator. Methods for the isolation of RNA and SDS total protein are described below.

For $\mathrm{CdCl}_{2}$ exposure, subculture, feeding and maintaining of cells before the experiment were the same as those for sodium arsenite exposure. A $53.4 \mu \mathrm{M}$ $\mathrm{CdCl}_{2}$ solution in freshly prepared complete serum-free medium was made just prior to exposing the cells. RNA and SDS total protein samples were obtained in triplicate no more than one hour prior to the start of the experiment. Cells were fed with $2 \mathrm{ml}$ per well of the $53.4 \mu \mathrm{M} \mathrm{CdCl}$ solution, and incubated at standard conditions for four hours. RNA and SDS total protein samples were collected in triplicate at one, two and four hours of exposure to $\mathrm{CdCl}_{2}$. After 4 hours of exposure all of the cells were fed with $2 \mathrm{ml}$ of freshly prepared medium and incubated additionally for 48 hours. RNA and SDS total protein samples were obtained in triplicate for each recovery time point $(4,8,12,16,24,36$ and 48 
hours). Both the exposure and the recovery times were plotted from the time the plates entered the incubator. Methods for the isolation of RNA and SDS total protein are described below

For 16 days of $\mathrm{CdCl}_{2}$ exposure, subculture, feeding and maintaining of cells before the experiment were the same as those for sodium arsenite exposure. After seven days the cultures were confluent, 0.9, 2.2 and $4.5 \mu \mathrm{M}$ $\mathrm{CdCl}_{2}$ solutions were prepared in fresh serum-free medium. Cells were fed with one of the three concentrations of $\mathrm{CdCl}_{2}$ such that over a 16-day time course at least one concentration would result in appreciable cell death, or complete serum-free medium without $\mathrm{CdCl}_{2}$. $\mathrm{HK}-2$ cells were fed with same concentration of $\mathrm{CdCl}_{2}$ in fresh medium every 72 hours for 16 days. RNA and SDS total protein samples were isolated in triplicate from cultures 24 hours after each feeding. RNA and SDS total protein are described below.

\section{EXPOSURE OF HPT CELLS TO $\mathrm{CdCl}_{2}$ FOR 48 HOURS AND 16 DAYS FOR MT-3 EXPRESSION}

For 48 hours of $\mathrm{CdCl}_{2}$ exposure, T-75 flasks of HPT cell cultures were subcultured at a 1:2 subculture ratio into six-well plates. The cells were fed with 2 $\mathrm{ml}$ of fresh media 24 hours after subculture and every 72 hours until the experiment was initiated. The final feeding came 24 hours prior to starting the experiment. Cells were maintained at standard conditions for the duration of the experiment.

After seven days the cultures were confluent, 9, 27 and $45 \mu \mathrm{M} \mathrm{CdCl} 2$ solutions were prepared in fresh serum-free medium. HPT cells were exposed 
continuously to one of the three concentrations of $\mathrm{CdCl}_{2}$ or complete serum-free medium without $\mathrm{CdCl}_{2}$ for 48 hour time course. RNA and SDS total protein samples were isolated in triplicate from cultures. RNA and SDS total protein are described below.

For 16 days of $\mathrm{CdCl}_{2}$ exposure, T-75 flasks of HPT cell cultures were subcultured at a 1:2 subculture ratio into six-well plates. The cells were fed with 2 $\mathrm{ml}$ of fresh serum-free media every 72 hours after subculture for seven days. After seven days the cultures were confluent, the same concentrations of $\mathrm{CdCl}_{2}$ solutions used for 48 hours of $\mathrm{CdCl}_{2}$ exposure of HPT cells were prepared in fresh serum-free medium. Cells were fed with one of the three concentrations of $\mathrm{CdCl}_{2}$ or complete serum-free medium without $\mathrm{CdCl}_{2}$. Subsequent feeding HPT cells and isolating samples were the same as those of HK-2 cells. RNA and SDS total protein samples were isolated in triplicate from cultures 24 hours after each feeding. RNA and SDS total protein are described below.

\section{ISOLATION OF RNA}

RNA was isolated from HPT and HK-2 cells using the TRI Reagent ${ }^{\circledR}$ protocol (Molecular Research Center, Inc. Cincinnati, OH, USA). Samples were prepared first by moving media from the well or flask and rinsing the cells with PBS. The PBS wash was discarded and $1 \mathrm{ml}$ of TRI Reagent ${ }^{\circledR}$ was added per well of a six-well plate $(2 \mathrm{ml}$ per T-25 flask). Cells were incubated at room temperature for 10 minutes to completely disrupt cells. Cell lysates were passed several times through a sterile $1 \mathrm{ml}$ pipette to shear DNA before transferring to a sterile $1.5 \mathrm{ml}$ microfuge tube. The cell lysates were stored at $-70^{\circ} \mathrm{C}$. 
To isolate RNA, samples were thawed at room temperature and a $100 \mu \mathrm{l}$ of 1-bromo-3-chloropropane (BCP) reagent was added to each tube. The tubes were vortexed vigorously for 30 seconds, centrifuged at $4^{\circ} \mathrm{C}$ for 10 minutes at $12,000 \times \mathrm{g}$, and the transparent upper aqueous phases were transferred to clean RNase-free microfuge tubes. To the aqueous layer, $500 \mu$ of isopropanol was added to precipitate the RNA and the tubes were gently inverted several times. Samples were incubated at room temperature for 10 minutes and then centrifuged for 10 minutes at $12,000 \times \mathrm{g}$. The supernatant was removed and the RNA pellets were washed twice with $1 \mathrm{ml}$ of $75 \%$ ethanol. The pellets were thoroughly dried at room temperature for 10 minutes. Cell pellets were resuspended in 20 to $50 \mu \mathrm{l}$ of RNase-free water and stored at $-70^{\circ} \mathrm{C}$.

RNA samples were quantitated by combining $3 \mu$ of each stock RNA sample with $97 \mu$ l of PBS in a microfuge tube. The samples were analyzed in a spectrophotometer and the absorbance was read at $260\left(\mathrm{~A}_{260}\right)$ and $280 \mathrm{~nm}$ $\left(A_{280}\right)$. The concentrations were calculated by multiplying the absorbance at 260 $\mathrm{nm}$ by $40 \mu \mathrm{g} / \mathrm{ml}$ and by the volume of the sample $(100 \mu \mathrm{l})$, and dividing that product by the volume of the RNA sample $(3 \mu \mathrm{l})$. The ratio of $A_{260} / A_{280}$, which should be around 2.0, was measured to check the purity of RNA samples. A portion of stock RNA samples were diluted to working concentrations of $0.167 \mu \mathrm{g} / \mu \mathrm{l}$ in RNase-free tubes and stored at $-70^{\circ} \mathrm{C}$.

\section{REVERSE TRANSCRIPTION-POLYMERASE CHAIN REACTION (RT-PCR)}

Aliquots of $1.5 \mu \mathrm{l}(0.25 \mu \mathrm{g})$ of total RNA samples were transferred to sterile PCR reaction tubes placed on a PCR rack on ice. Two negative control tubes, 
one that contained $1.5 \mu \mathrm{l}$ of water and the other containing $1.5 \mu \mathrm{l}$ of a random aliquot of RNA where no RT was added were prepared with each reaction. An RT master mix was prepared from a Perkin-Elmer GeneAmp RNA PCR Core Kit (Perkin-Elmer-Cetus, Foster City, CA, USA, Part No. N808-0017) by combining $5 \mathrm{mM} \mathrm{MgCl}$, 1x PCR Buffer II, $1 \mathrm{mM}$ dATP, $1 \mathrm{mM}$ dCTP, $1 \mathrm{mM}$ dGTP, $1 \mathrm{mM}$ dTTP, $2.5 \mathrm{mM}$ random hexamers, $1 \mathrm{U} / \mu \mathrm{l}$ RNase inhibitor and $2.5 \mathrm{U} / \mu \mathrm{l} \mathrm{MuLV}$ reverse transcriptase in a microfuge tube. Ice-cold RT master mix reagents were mixed by vortexing and $8.5 \mu \mathrm{l}$ of the master mix reagents were added to the tubes containing the RNA samples. The rack of tubes was placed in a DNA thermocycler (Perkin-Elmer Applied Biosystems GeneAmp PCR System 9700). The condition of RT step for all the samples in the thermocycler was applied to any mixture of RNA and RT master mix - one cycle of $25^{\circ} \mathrm{C}$ for 10 minutes, $42^{\circ} \mathrm{C}$ for 20 minutes, $99^{\circ} \mathrm{C}$ for 5 minutes, and $5^{\circ} \mathrm{C}$ for 10 minutes.

During RT step, PCR master mixes were prepared with $2 \mathrm{mM} \mathrm{MgCl}, 1 \mathrm{x}$ PCR Buffer II, UP and LOW (or Upstream and Downstream) primers (see Appendix B, PCR primers), 1.25 U Taq DNA polymerase and water to make the final volume of $40 \mu \mathrm{l}$ per aliquot. The $\mathrm{MgCl}_{2}, \mathrm{PCR}$ Buffer II and Taq polymerase were used from the Perkin-Elmer GeneAmp RNA PCR Core Kit. The tube was vortexed and $40 \mu \mathrm{l}$ aliquots were added to the RT reaction tubes after the RT step was finished. PCR step was perfomed at the cycle temperatures and cycle numbers, depending on the expected PCR product (see Appendix B, PCR temperatures and cycles). After the first denaturation, each cycle had an annealing of primers, a polymerization, and a denaturation. Fifteen microliters of 
PCR products were transferred from each reaction tube at the sampling cycles to each new $1.5 \mathrm{ml}$ microfuge tube containing $1.5 \mu \mathrm{l}$ of 10x DNA loading buffer (for 10X: $0.4 \%$ bromophenol blue, $0.4 \%$ xylene cyanol $\mathrm{FF}$, and $50 \%$ glycerol in water. A $2 \%$ agarose gel containing ethidium bromide (EtBr) was made to visulalize RT-PCR products. It was prepared by mixing 6 grams of PE-Xpress GeneAmp Agarose (Perkin-Elmer, Cat No. 930-2774) with $300 \mathrm{ml}$ of 0.5X TBE Buffer (Gibco-BRL, Cat No. 15546-013) to make 3 gels for 3 different sampling cycles. The mixture was heated in a microwave for approximately 2 minutes until the agarose was completely in solution and $2.5 \mu \mathrm{l}$ of $10 \mathrm{mg} / \mathrm{ml} \mathrm{EtBr}$ was added to the solution after the agarose solution cooled down to around $50^{\circ} \mathrm{C}$. Then, the solution was poured into a gel mould and combs were put on it. The combs were removed after the gels were solidified and the gels were placed in an electrophoresis apparatus containing 0.5X TBE buffer. Five microliters of Hi-Lo DNA markers (Minnesota Molecular, Cat. No. 1010) and $10 \mu \mathrm{l}$ aliquots of RTPCR products with 10x DNA loading buffer were loaded into the wells. The gels were run at $250 \mathrm{mV}$ and 150 amps for approximately 1.5 hours, and visualized on a UV Transilluminator (Fisher Scientific). Digital images of the gels were taken using a KODAK Professional DCS 420 digital camera interfaced with Adobe Photoshop $\vartheta$ software, and integrated optical densities (IODs) of the RT-PCR product bands were quantitated using Kontron KS 400 image analysis software (Carl Zeiss Vision, Thornwood, NY, USA). The resulting IODs were used to generate a relative IOD that is the ratio of the respective PCR product to that of the housekeeping gene, g3pdh (glyceraldehyde 3-phosphate dehydrogenase). 


\section{DETERMINATION OF CELL VIABILITY}

Cells grown on 6-well plates $\left(9.4 \mathrm{~cm}^{2}\right.$ per well) were washed with PBS, treated with DAPI (4',6-diamidino-2-phenylindole) nuclear stain, and then an automatic counting program was executed on a Roche image analysis computer. Nuclear staining was determined under fluorescent illumination at $40 \mathrm{X}$ magnification on the Zeiss Axiovert linked to a Roche workstation equipped with Kontron KS 400 software. For each time point, the nucleus stained with DAPI in 3 wells and 20 random fields per well were counted. Viability was expressed as a percent of control value.

\section{ISOLATION OF PROTEIN}

For analysis of heat shock proteins, cell media was removed and the cells were rinsed with PBS. After removal of PBS, a $500 \mu$ l per well for six well plates of $1 x$ SDS lysis buffer (see Appendix C) was added to the cells. The cells were incubated at room temperature for ten minutes. Cell lysates were transferred to $1.5 \mathrm{ml}$ microfuge tubes and stored at $-20^{\circ} \mathrm{C}$. The tubes with stop caps were boiled for 10 minutes and then the samples were passed through a 22 gauge needle several times to remove their stickiness.

For analysis of metallothioneins, cell media was removed and the cells were rinsed with PBS. After removal of PBS, $500 \mu \mathrm{l}$ per well for 6 well plates of $10 \mathrm{mM}$ Tris-Cl ( $\mathrm{pH} 8.0)$ was added and the cells were scraped using Disposable cell scraper (Sarstedt, Inc., Newton, N.C., USA). The scraped cells were transferred to $1.5 \mathrm{ml}$ microfuge tubes, $50 \mu \mathrm{l}$ of $1 \mathrm{M}$ Tris- $\mathrm{Cl}(\mathrm{pH} 8.8)$ and $50 \mu \mathrm{l}$ of 1M DTT (dithiothreitol) were added to the cells. The cells were subjected to 
freeze-thaw between liquid nitrogen and $37^{\circ} \mathrm{C}$ water bath two times for 2 minutes each, then centrifuged at $12000 \times \mathrm{g}$ for $10 \mathrm{~min}$ to take the supernatant, which was centifuged with Ultrafree-0.5 Centrifugal Filter Device (30 kD molecular weight cutoff, Millipore). The filtrate was stored $-20^{\circ} \mathrm{C}$.

\section{PROTEIN DETERMINATION}

Bicinchoninic acid (BCA) Copper Reduction Method (Pierce Chemical Co., Rockford, IL, USA) for heat shock proteins was used to determine protein concentrations for each of the samples. Although BCA protein assay is more sensitive, it is not useful in metallothioneins because they can affect chelation of copper by BCA. Instead, Bio-Rad Protein Assay (Bio-Rad, Hercules, CA, USA) for metallothionein was used, since it is dye-binding assay.

Ten $\mu \mathrm{g} / \mu$ of bovine serum albumin (BSA, Fischer Scientific, Fair Lawn, NJ, USA. Cat No. BP1605-100) was used to make standard solutions containing $0,1,2,4,8,12,16$ and $20 \mu \mathrm{g}$ of BSA per 10 :I. First two wells of 96 -well plate were blank (10 $\mu$ l of water and $5 \mu \mathrm{l}$ of $1 \times$ SDS lysis buffer or $10 \mathrm{mM}$ Tris-Cl) and standards containing $10 \mu \mathrm{l}$ of each standard solution and $5 \mu \mathrm{l}$ of $1 \mathrm{x}$ SDS lysis buffer were loaded in duplicate wells. Five $\mu$ of SDS protein samples were mixed with $10 \mu \mathrm{l}$ of deionized water and loaded in triplicate wells. For quantitation of heat shock proteins, one part copper sulfate (BCA Reagent B, Pierce Cat No. 23224) was mixed with 50 parts bicinchoninic acid solution (BCA Reagent A, Pierce Cat No. BK45047) and $200 \mu \mathrm{l}$ was added to each well using a multi-

channel pipette aid. For quantitation of metallothioneins, Bio-Rad Protein Assay was filtered and diluted to $1 / 5$ to be used. The samples with BCA were incubated 
at $37^{\circ} \mathrm{C}$ for $30 \mathrm{~min}$ or the samples with Bio-Rad Protein Assay were incubated at room temperature for $5 \mathrm{~min}$, and then scanned using a Dynatech MR5000 plate reader (Dynatech Inc., Guernsey Channel Islands). Each protein concentration was calculated by the regression of standard optical densities.

\section{WESTERN BLOT FOR HSP PROTEIN DETERMINATION}

A $12.5 \%$ resolving gel was prepared (see Appendix C). After 15 min degasing, $10 \%$ ammonium persulfate (APS) and TEMED were added to the gel followed by loading into a $1.5 \mathrm{~mm}$ thick slab gel mold. Deionized water was added onto the gel to block penetration of air into the gel and to help hardening.

While the resolving gel was solidifying for $30 \mathrm{~min}$, a $4 \%$ stacking gel was prepared (see Appendix C) and de-gased for 15 minutes. The stacking gel solution was loaded onto the resolving gel following the addition of TEMED and $10 \%$ APS. The comb was inserted and the stacking gel was solidified for 30 minutes.

The slab gel was put into a Hoefer Small Gel Caster apparatus (Hoefer Scientific Instruments, San Francisco, CA, USA) which was filled with $1 x$ Tris/Glycine/SDS Buffer (BioRad Laboratories, Hercules, CA, USA. Cat. \#1610732). Two $\mu \mathrm{g}$ of samples in HK-2 cells were mixed with 4x SDS loading dye, and loaded into wells. The gel was run at an initial voltage of $80 \mathrm{mV}$ until the dye passed through the stacking gel layer, and then the voltage was increased to 120 $\mathrm{mV}$ for 1.5 hours to run the dye near the bottom of the gel. The gel was taken from the apparatus to the transfer buffer (Appendix C) in a small tray, and shaken for $5 \mathrm{~min}$. For each gel, two $6 \mathrm{~cm} \times 9 \mathrm{~cm}$ sections of $3 \mathrm{~mm}$ Whatmann filter paper 
were cut and soaked with two sponge beds in transfer buffer. A $5 \mathrm{~cm} \times 8 \mathrm{~cm}$ square of Sequi-Blot ${ }^{\mathrm{TM}}$ PVDF membrane (Bio-Rad, Cat No. 162-0182) was cut and soaked briefly in $100 \%$ methanol and then placed in transfer buffer. A wet blot was made in this order from the bottom to top - sponge bed, filter paper, gel, PVDF membrane, second filter paper, and second sponge bed. All the materials in the blot were soaked in transfer buffer. The smooth side of the PVDF membrane faced the gel. A pipette was rolled over the membrane several times to remove bubbles. The blot was placed in a BioRad Trans-Blot ${ }^{\circledR}$ transfer apparatus filled with transfer buffer and run at $22 \mathrm{mV}$ overnight at $4^{\circ} \mathrm{C}$.

The following day, the membrane was removed from the transfer buffer and placed in $1 \mathrm{x}$ PBS. The membrane was incubated in $10 \%$ skim milk in $1 \mathrm{X}$ PBS at room temperature with shaking for one hour. The membrane was quickly washed three times in $1 \times$ PBS and three times again for 10 minutes each wash. The membrane was incubated in appropriate primary antibody (Appendix C) at room temperature for 1 hour with constant agitation. The membrane was washed quickly three times with $1 \mathrm{x}$ PBS and three additional times for 10 minutes each wash. The membrane was incubated in appropriate secondary antibody (Appendix C) at room temperature for 1 hour with constant agitation. Two 10 minute washes in 1x PBS and one wash for 10 minutes in alkaline phosphatase buffer (Appendix C) were done with the membrane.

Colorimetric immuno-staining of the alkaline phosphatase conjugated secondary antibodies was performed using an alkaline phosphatase Vectastain ABC-AP kit (Vector Laboratories, Burlingame, CA, USA). The membrane was 
soaked in $25 \mathrm{ml}$ of alkaline phosphatase buffer, and ten drops in the order of Reagents 1,2 and 3 were added. Detection times were 1 to 2 minutes, depending on the standards. The membrane was rinsed immediately in tap water when the control wells became visible, and left to air dry overnight. An Epson ${ }^{\circledR}$ Expression 63 color scanner and Adobe ${ }^{\circledR}$ Photoshop ${ }^{\circledR}$ software were used to obtain a digital image. The intensity of the protein bands was quantitated as integrated optical densities (IODs) using Kontron KS 400 image analysis software, and samples were quantitated to standards using linear regression in Microsoft Excel.

\section{ANALYSIS OF HSP 27 PHOSPHOISOFORMS}

Proteins were extracted from cell monolayers with $9 \mathrm{M}$ urea, $1 \mathrm{mM}$ phenylmethylsulfonyl fluoride, $10 \mathrm{mM} \quad \mathrm{NaF}, \quad 2 \%$ ampholines, $5 \% \quad \exists-$ mercaptoethanol, and $2 \%$ Triton $X-100$. The proteins were focused on $4 \%$ polyacrylamide capillary tube gels containing $9 \mathrm{M}$ urea, 1.5\% 5/7 Biolyte, 0.5\% 3/10 Biolyte ampholines (Biorad, Hercules, CA). Capillary tube gels containing focused proteins were placed at the top of $12 \%$ polyacrylamide slab minigels, followed by separation of proteins in the second dimension. Resolved proteins were electrotransferred onto polyvinylidene difluoride (PVDF) membranes (Biorad). The hsp 27 phosphoisoforms were detected using procedures identical to those described for Western Blot.

\section{DOT BLOTS FOR MT-3 PROTEIN DETERMINATION}

Standards $(0,0.01,0.03,0.1,0.3,1,2$ and $4 \mathrm{ng})$ were prepared with 1.5 times conjugated synthetic peptide (Sigma Chemical Co., St Louis, MO) specific 
to MT-3 and $3 \mu \mathrm{g}$ of HPT or HK-2 total protein. The standard and the sample were dissolved in a total volume of $75 \mu \mathrm{l}$ with PBS within a 96-well plate. A volume of $75 \mu \mathrm{l}$ of $3 \%$ glutaraldehyde was added to each well using a multichannel pipetman. Plates were kept at room temperature for 30 minutes while the dot blot apparatus was being prepared.

For each blot, an $8 \mathrm{~cm} \times 12 \mathrm{~cm}$ piece of Sequi-Blot ${ }^{\mathrm{TM}}$ PVDF membrane (Bio-Rad, Cat No. 162-0182) was cut and soaked in methanol and then transferred to a solution of PBS. Using a syringe, the dot blot apparatus was assembled by filling the lower chamber of the apparatus with approximately 50 $\mathrm{ml}$ of PBS. The PVDF membrane was carefully placed over the holes of the plastic adapter while the syringe remained attached to the drain tube, confirming that no bubbles were generated. The top plate was secured to the lower chamber, and each well was filled with $600 \mu$ of PBS. The plunger of syringe was used to pull carefully about $50 \mathrm{ml}$ of PBS from the apparatus, so that the wells began to drain by gravity. The syringe was removed from the apparatus and flow of PBS was collected in a beaker.

After the PBS had drained to the surface of the membrane, $100 \mu \mathrm{l}(2 \mu \mathrm{g}$ total protein) out of $150 \mu \mathrm{l}$ of the samples was loaded onto the membrane using a multichannel pipetman. When the samples drained completely to the surface of the membrane followed by rinsing twice with $400 \mu \mathrm{l}$ of PBS in each well, the apparatus was loosen and the blot was kept in PBS overnight at $4^{\circ} \mathrm{C}$.

The following day, the membrane was incubated in $3 \%$ bovine serum albumin (BSA, Fischer Scientific, Fair Lawn, NJ, USA. Cat No. BP1605-100) in 
1X PBS at room temperature with shaking for one hour. The membrane was quickly washed three times in 1x PBS and three times again for 10 minutes each wash. The membrane was incubated in the primary antibody (MT-3 polyclonal antibody, Appendix C) at room temperature for 1 hour with constant agitation. The membrane was washed quickly three times with $1 \times$ PBS and three additional times for 10 minutes each wash. The membrane was incubated in appropriate secondary antibody (Appendix C) at room temperature for 1 hour with constant agitation. Two 10 minute washes in 1x PBS and one wash for 10 minutes in alkaline phosphatase buffer (Appendix C) were done with the membrane. Colorimetric immuno-staining and quantitation were the same as those in western blot.

\section{STABLE TRANSFECTION OF HK-2 CELLS}

The MT-3 coding sequence was cloned from cultured HPT cell RNA by RT-PCR using MT-3 specific primers. The MT-3 coding sequence was blunt end ligated into the EcoR V site of pcDNA3.1/Hygro (+) (Invitrogen, Carsbad CA). This vector has a cytomegalovirus immediate-early promoter upstream of the multiple cloning site and a hygromycin B resistance gene driven by an SV40 early promoter. The DNA construct was linearized by Fsp I before transfection. The HK-2 cells were transfected with the MT-3 plasmid construct in the sense

direction or the vector alone by using Effectene ${ }^{\mathrm{TM}}$ transfection reagent (Qiagen, Valenecia CA).

HK-2 cells were seeded at a $50 \%$ confluence on a 6 -well plate $\left(9.6 \mathrm{~cm}^{2} /\right.$ well) the day before transfection. Next day, $4 \mu \mathrm{l}$ of linearized MT-3 
pcDNA $3.1(0.1 \mu \mathrm{g} / \mu \mathrm{l})$ was mixed with $96 \mu \mathrm{l}$ of EC buffer by vortexing for $1 \mathrm{sec}$, and $3.2 \mu \mathrm{l}$ of enhancer was added to the mixture. The mixture was incubated at room temperature for $5 \mathrm{~min}$. Then, $10 \mu \mathrm{l}$ of effectene was added to the mixture, vortexing for $10 \mathrm{sec}$, and incubating for $10 \mathrm{~min}$ at room temperature. The HK-2 cells were washed with $1 \mathrm{X}$ PBS and $1.6 \mathrm{ml}$ of growth medium was added to the cells. Six hundred $\mu \mathrm{l}$ of growth medium was mixed with the DNA/effectene solution by pipetting up and down twice and added to the cells. The cells were incubated for 24 hours at $37^{\circ} \mathrm{C}$. The cells were treated with $0.5 \mathrm{ml}$ of trypsinEDTA (Gibco-BRL, Cat No. 25300-062), and the plate was placed on a $37^{\circ} \mathrm{C}$ hot plate. The cells were trypsinized until they appeared completely dissociated (approximately 10 minutes) and the cell suspension was transferred to a $15 \mathrm{ml}$ conical tube. The plate was rinsed with $5 \mathrm{ml}$ of PBS, and the wash was added to the tube containing the trypsinized cells. The tube was centrifuged for 5 minutes at $10,000 \mathrm{rpm}$, after which the supernatant was removed and the cell pellet was thoroughly resuspended in $10 \mathrm{ml}$ of medium ( 10\% confluency). Aliquots of $2 \mathrm{ml}$ of cell suspension were transferred to a new 6-well plate, and incubated for 24 hours. Selection was carried out with growth medium containing $30 \mu \mathrm{g} / \mathrm{ml}$ hygromycin B. Clones were selected using cloning rings and propagated in media containing $30 \mu \mathrm{g} / \mathrm{ml}$ hygromycin B. The stable transfectants were identified, recloned and preserved in liquid nitrogen storage. 


\section{REFERENCES}

1. Sens, D. A., Detrisac, C. J., Sens, M. A., Rossi, M. R., Wenger, S. L., and Todd, J. H. Tissue culture of human renal epithelial cells using a defined serum-free growth formulation. Exper. Nephrol. 7:344-352,1999.

2. Ryan, M. J., Johnson, G., Kirk, J., Fuerstenberg, S. M., Zager, R. A., and Torok-Storb, B. HK-2: An immortalized proximal tubule epithelial cell line from normal adult human kidney. Kidney Int. 45:48-57, 1994. 


\section{EXPRESSION OF HSP 27, HSP 60, HSC 70 AND HSP 70 BY IMMORTALIZED HUMAN PROXIMAL TUBULE CELLS (HK-2) FOLLOWING EXPOSURE TO HEAT SHOCK, SODIUM ARSENITE, OR CADMIUM CHLORIDE ${ }^{1}$}

1 The contents of this chapter were published in August 2001 in Journal of Toxicology and Environmental Health 63(7):475-493. 


\section{INTRODUCTION}

The aim of this chapter was to determine if the immortalized human proximal tubule cell line, HK-2, would retain the basic features of the responses to classic heat shock, sodium arsenite, and $\mathrm{CdCl}_{2}$, similar to those demonstrated for the mortal HPT cells $(1,2,3)$. The previous reports showed that there is a rapid induction of both mRNA and protein of the hsp 27 , hsp 60 , and hsp 70 genes in the mortal HPT cells by exposure to heat or sodium arsenite, while the expression of the cognate isoform of hsp 70 , hsc 70 remained unaffected by such exposure. Acute exposure to $\mathrm{Cd}^{+2}$ increased the expression of hsp 27 and hsp 60 mRNA and protein, while the expression of hsc70 mRNA and protein was largely unchanged. The induction of hsp 70 was reduced under acute exposure of $\mathrm{Cd}^{+2}$ when judged against the elevated levels of expression produced by heat and sodium arsenite. These studies suggested that under acute exposure of $\mathrm{Cd}^{+2}$, the expression of hsp 70 might be compromised when compared to expression of hsp 27, hsp 60, and hsc 70, all of which showed the classic patterns of expression expected of the heat shock proteins. In addition, there was no increase in any of above hsps when HPT cells were exposed to lethal and sub-lethal levels of $\mathrm{Cd}^{+2}$ over an extended period of exposure.

One of the best ways to study the functions of hsps against $\mathrm{Cd}^{+2}$-induced nephrotoxicity would be through the isolation and use of stable transfectants of HPT cells that overexpress the respective hsp genes. The HPT cells, having a defined mortal life span, cannot serve as a recipient in stable transfection protocols. For this purpose, the HK-2 cell line derived from primary HPT cells and immortalized by transfection with the $\mathrm{HPV} E_{6} / E_{7}$ genes were chosen for this 
study (4). This cell line has been shown to be immortal, non-tumorigenic, and to produce monolayer cell cultures that retain many features expected of welldifferentiated proximal tubule cells.

\section{RESULTS}

Expression of hsp 27 mRNA and protein in HK-2 cells acutely exposed to heat shock, sodium arsenite, and $\mathrm{CdCl}_{2}$. The effect of heat shock on the expression of hsp 27 was determined by exposing confluent HK-2 cells to an elevated temperature of $42.5^{\circ} \mathrm{C}$ for 1 hour followed by a recovery period of 48 hour at $37^{\circ} \mathrm{C}$. The expression of hsp 27 mRNA was determined by comparing the IOD values of hsp 27 mRNA to that of the housekeeping gene g3pdh, yielding the relative IODs at each analysis point over the time course of heat treatment and recovery (Figure 1A). It was demonstrated that heat shock resulted in an approximate 2-fold increase in hsp 27 mRNA levels following 1 hour of heat shock, and this increase extended into the first 4 hour of the recovery period and thereafter returned to control values. However, the increases were not significant compared to the control. It was demonstrated that heat shock resulted in a significant increase in hsp 27 protein following heat shock and extending to the end of the 48-hour recovery period (Figure 1B). An analysis of the phosphoisoforms of hsp 27 demonstrated that heat shock caused a shift to the more phosphorylated state (Figure 2). The control cells possessed a mixture of nonphosphorylated and monophosphorylated hsp 27 , while immediately following heat treatment the cells demonstrated a reduction in the nonphosphorylated 
isoform and a shift to the mono-, bi-, and triphosphorylated isoforms. By the end of the 48-hour recovery period, the hsp 27 isoform profile was identical to that of the control.

The expression of hsp 27 was also determined by exposing confluent HK2 cells to 100 :M sodium arsenite for 4 hours followed by a 48-hour recovery period (Figure 1, C and D). It was demonstrated that both hsp 27 mRNA and protein had significant increase in level as a result of sodium arsenite treatment. The hsp 27 mRNA increased approximately 3-fold following sodium arsenite exposure and returned to control values following 24 hours of recovery in the absence of sodium arsenite (Figure 1C). The level of the hsp 27 protein was increased approximately 3-fold within 1 hour of sodium arsenite exposure and remained elevated throughout the recovery period (Figure 1D). However, it was demonstrated that $\mathrm{Cd}^{+2}$ had no significant effect on the levels of hsp 27 mRNA or protein (Figure 1, E and F).

Expression of hsp 60 mRNA and protein in HK-2 cells acutely exposed to heat shock, sodium arsenite, and $\mathrm{CdCl}_{2}$. Identical total $\mathrm{RNA}$ and protein samples from the analysis already described of hsp 27 expression were used to determine the expression of hsp 60 mRNA and protein in HK-2 cells exposed to heat, sodium arsenite, and $\mathrm{CdCl}_{2}$. It was demonstrated that there was no change of the expression of hsp 60 mRNA and protein in the HK-2 cells when exposed to a heat shock and subsequent recovery period (Figure $3, \mathrm{~A}$ and $\mathrm{B}$ ). When the HK-2 cells were exposed to sodium arsenite, there was a small elevation in the levels of hsp 60 mRNA and protein at a few points in the time 

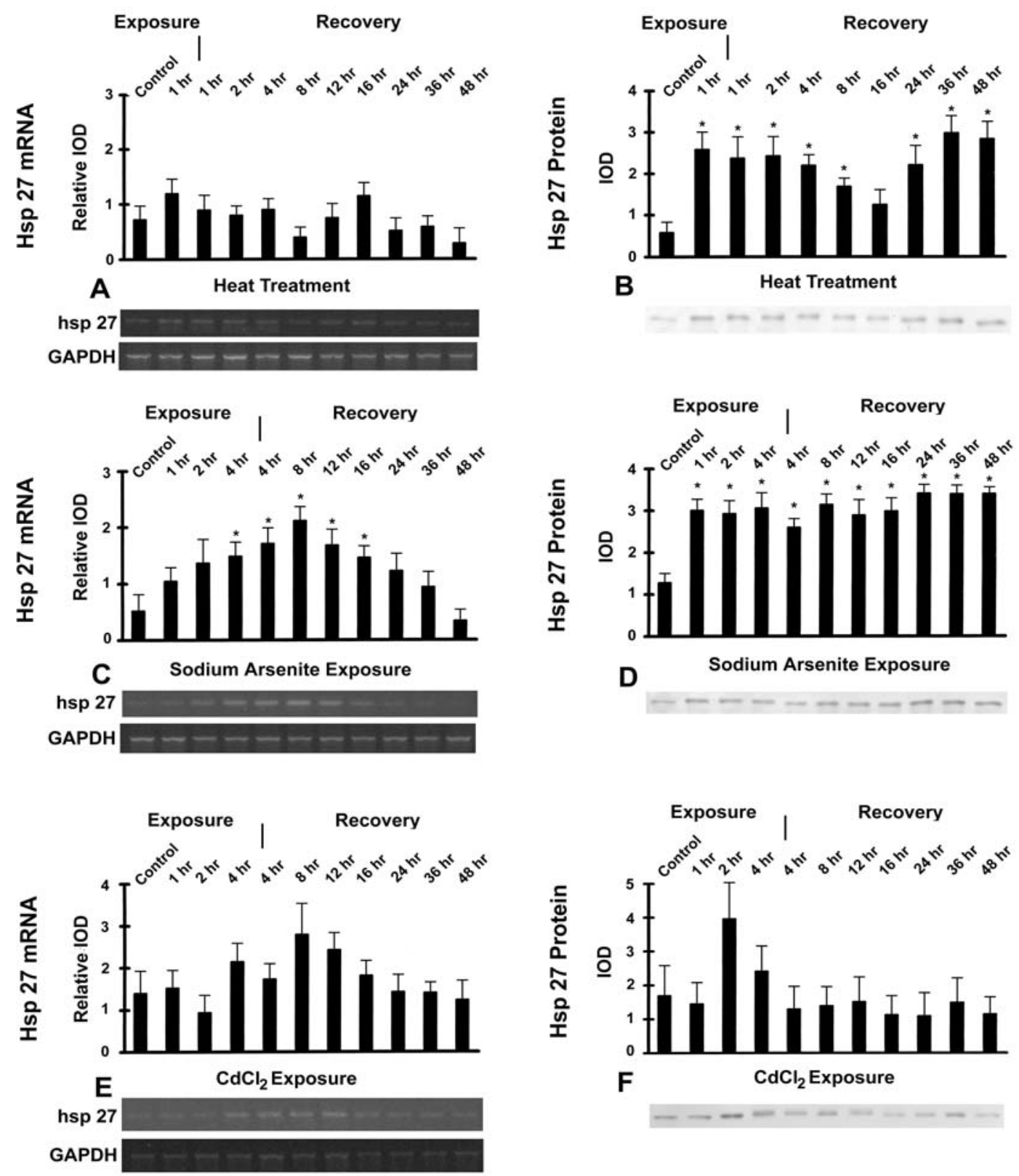

Figure 1. Expression of hsp $27 \mathrm{mRNA}$ and protein in HK-2 cells acutely exposed to heat shock, sodium arsenite, or $\mathrm{CdCl}_{2}$. (A, B) HK-2 cells exposed to heat shock $\left(42.5^{\circ} \mathrm{C}\right)$ for $1 \mathrm{hr}$ then returned to $37^{\circ} \mathrm{C}$ for a $48 \mathrm{hr}$ recovery period. (A) Relative IOD of bands representing hsp 27 mRNA. (B) IOD of bands representing hsp 27 protein. (C, D). HK-2 cells exposed to $100 \mu \mathrm{M}$ sodium arsenite for $4 \mathrm{hr}$, followed by a $48 \mathrm{hr}$ recovery period. (C) Relative IOD of bands representing hsp 27 mRNA. (D) IOD of bands representing hsp 27 protein. (E, F) HK-2 cells exposed to $53.4 \mu \mathrm{M} \mathrm{CdCl} 2$ for $4 \mathrm{hr}$, followed by a $48 \mathrm{hr}$ recovery period. (E) Relative IOD of bands representing hsp 27 mRNA. (F) IOD of bands representing hsp 27 protein. Asterisk indicates significant difference (at 0.05 or below) compared to control. 
a b c d

Control

\title{
Exposure $1 \mathrm{hr}$
}

\author{
Recovery $1 \mathrm{hr}$
}

\author{
$4 \mathrm{hr}$
}

\section{$48 \mathrm{hr}$}

Figure 2. Two-dimensional gel electrophoresis of heat-shocked HK-2 cells during exposure and recovery periods. Abbreviations : $a$, unphosphorylated; $b$, one serine phosphorylated; $\mathrm{c}$, two serines phosphorylated; $d$, three serines phosphorylated. Blot showing increasing phosphorylation of hsp 27 protein represented by the $a, b, c$ and d phosphoisoforms. 
course. There was a significant increase in hsp60 mRNA at 8 and 12 hours into the recovery period and an increase in hsp 60 protein beginning at 24 hours into the recovery period and remaining elevated at the end of the time course (Figure 3, C and D). Acute exposure of the HK-2 cells to $\mathrm{CdCl}_{2}$ was shown to have no effect on the levels of hsp 60 mRNA and protein (Figure 3, E and F).

\section{Expression of hsc 70 and hsp 70 mRNA and protein in HK-2 cells} acutely exposed to heat shock, sodium arsenite, and $\mathbf{C d C l}_{2}$. Identical total RNA and protein samples from the analysis already described were used to determine the expression of hsc 70 mRNA and protein in the HK-2 cells exposed to heat, sodium arsenite, and $\mathrm{CdCl}_{2}$. It was demonstrated that acute exposure of the HK-2 cells to heat, sodium arsenite, or $\mathrm{CdCl}_{2}$ had no effect on the expression of hsc 70 mRNA and protein (Figure 4, A-F). However, hsp 70 protein was markedly increased by exposure to heat, sodium arsenite, and $\mathrm{CdCl}_{2}$ (Figure 5 , A-C). For HK-2 cells acutely exposed to heat shock, sodium arsenite and $\mathrm{CdCl}_{2}$, hsp 70 increased within the exposure periods and remained elevated for the recovery of the 48 hour time course.

The hsp 70 protein is encoded by several genes, three of which (hsp 70A, $70 \mathrm{~B}, 70 \mathrm{C}$, respectively) have been sequenced and identified, and these can be individually determined using RT-PCR technology (2). Expression of mRNA for the hsp 70A gene was elevated in the HK-2 cells as a result of exposure to heat, sodium arsenite and $\mathrm{CdCl}_{2}$ (Figure 6, A-C). Compared to control, mRNA for the hsp 70B gene was increased in the HK-2 cells using identical assay conditions 

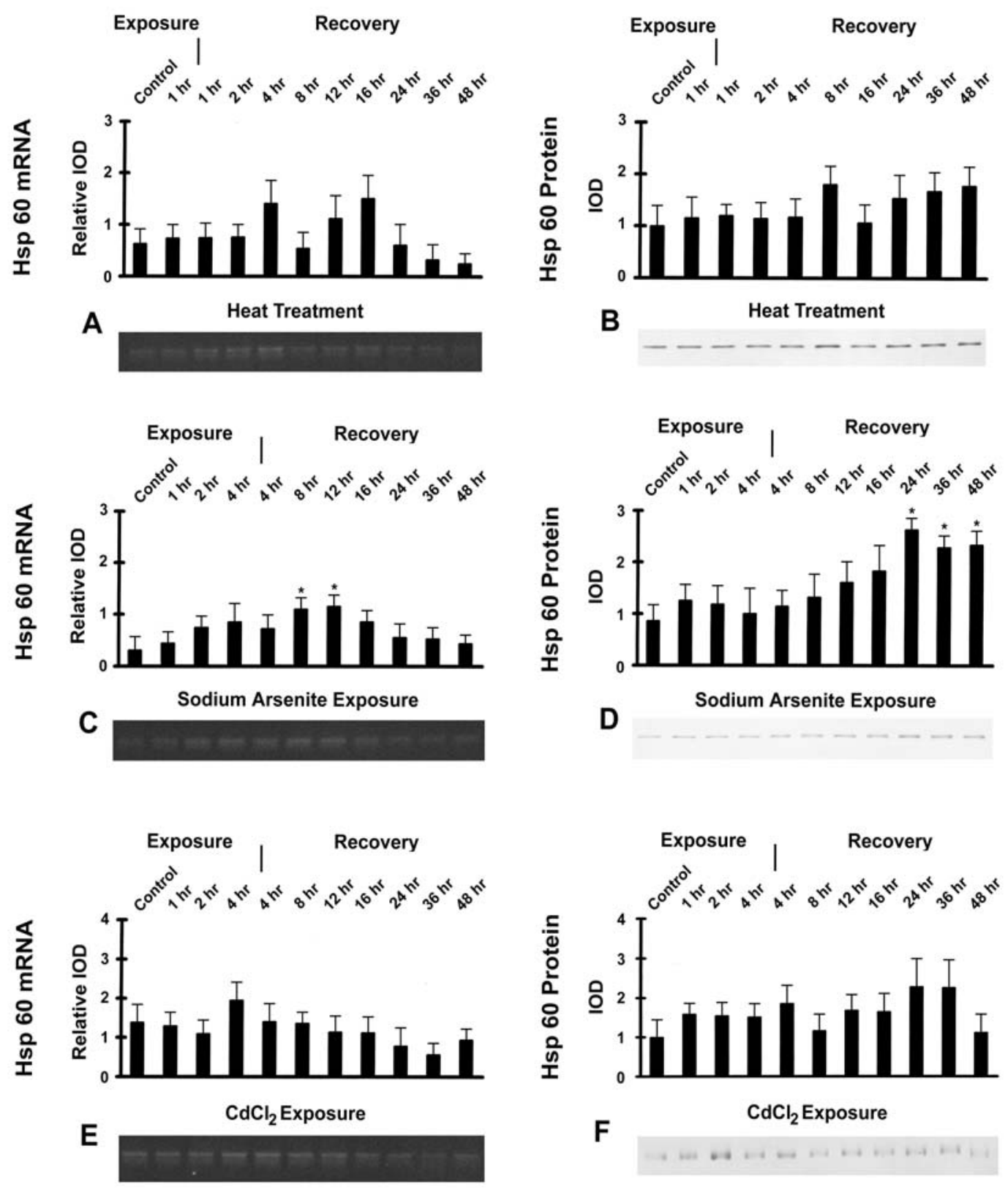

Figure 3. Expression of hsp $60 \mathrm{mRNA}$ and protein in HK-2 cells acutely exposed to heat shock, sodium arsenite, or $\mathrm{CdCl}_{2}$. (A, B) HK-2 cells exposed to heat shock $\left(42.5^{\circ} \mathrm{C}\right)$ for $1 \mathrm{hr}$ then returned to $37^{\circ} \mathrm{C}$ for a $48 \mathrm{hr}$ recovery period. (A) Relative IOD of bands representing hsp 60 mRNA. (B) IOD of bands representing hsp 60 protein. (C, D) HK-2 cells exposed to $100 \mu \mathrm{M}$ sodium arsenite for $4 \mathrm{hr}$, followed by a $48 \mathrm{hr}$ recovery period. (C) Relative IOD of bands representing hsp 60 mRNA. (D) IOD of bands representing hsp 60 protein. (E, F) HK-2 cells exposed to $53.4 \mu \mathrm{M} \mathrm{CdCl} 2$ for $4 \mathrm{hr}$, followed by a $48 \mathrm{hr}$ recovery period. (E) Relative IOD of bands representing hsp 60 mRNA. (F) IOD of bands representing hsp 60 protein. Asterisk indicates significant difference (at 0.05 or below) compared to control. 

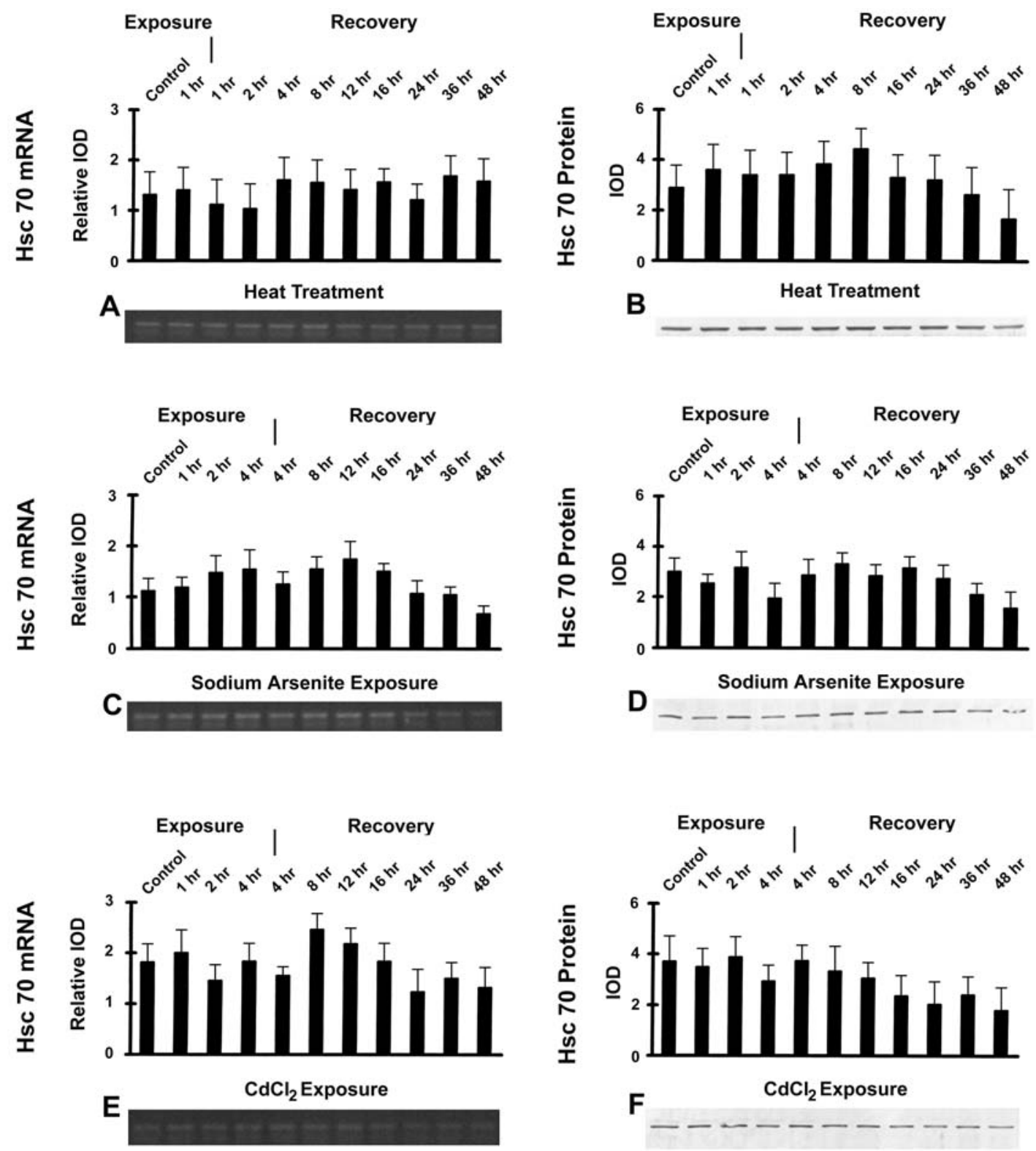

Figure 4. Expression of hsc 70 mRNA and protein in HK-2 cells acutely exposed to heat shock, sodium arsenite, or $\mathrm{CdCl}_{2}$. (A, B) HK-2 cells exposed to heat shock $\left(42.5^{\circ} \mathrm{C}\right)$ for $1 \mathrm{hr}$ then returned to $37^{\circ} \mathrm{C}$ for a $48 \mathrm{hr}$ recovery period. (A) Relative IOD of bands representing hsc 70 mRNA. (B) IOD of bands representing hsc 70 protein. (C, D) HK-2 cells exposed to $100 \mu \mathrm{M}$ sodium arsenite for $4 \mathrm{hr}$, followed by a $48 \mathrm{hr}$ recovery period. (C) Relative IOD of bands representing hsc 70 mRNA. (D) IOD of bands representing hsc 70 protein. (E, F) HK-2 cells exposed to $53.4 \mu \mathrm{M} \mathrm{CdCl} 2$ for $4 \mathrm{hr}$, followed by a $48 \mathrm{hr}$ recovery period. (E) Relative IOD of bands representing hsc 70 mRNA. (F) IOD of bands representing hsc 70 protein. There were no significant differences compared to the control. 

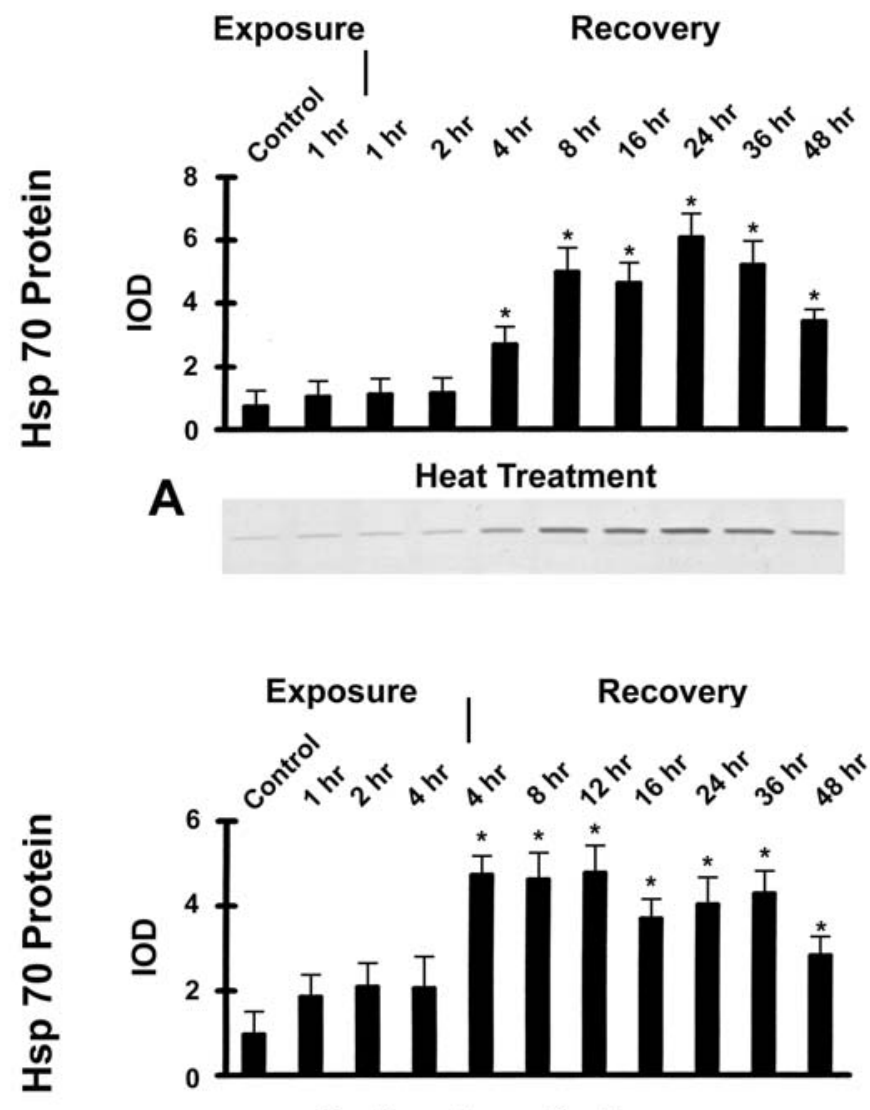

B

Sodium Arsenite Exposure

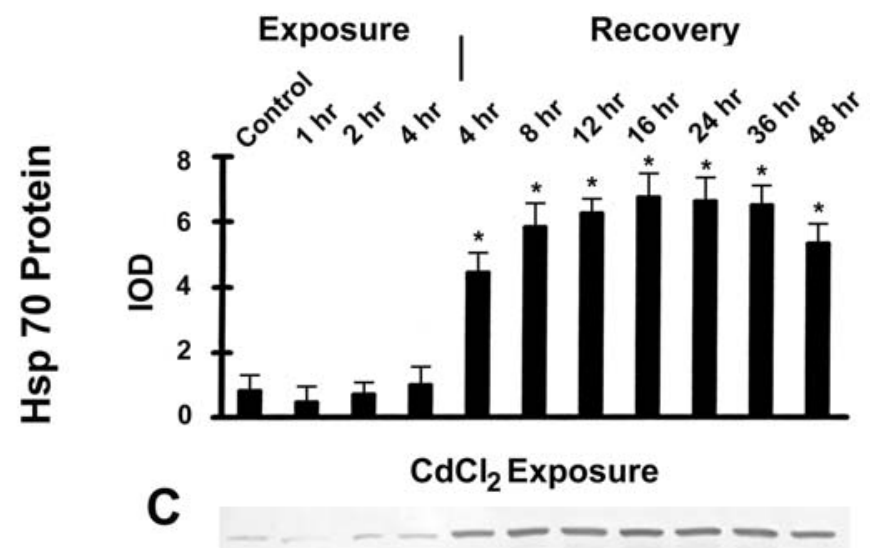

Figure 5. Western analysis of hsp 70 protein in HK-2 cells. IOD of bands representing hsp 70 protein for HK-2 cells exposed to heat shock (A), sodium arsenite $(\mathrm{B})$, or $\mathrm{CdCl}_{2}(\mathrm{C})$. Asterisk indicates significant difference (at 0.05 or below) compared to control. 

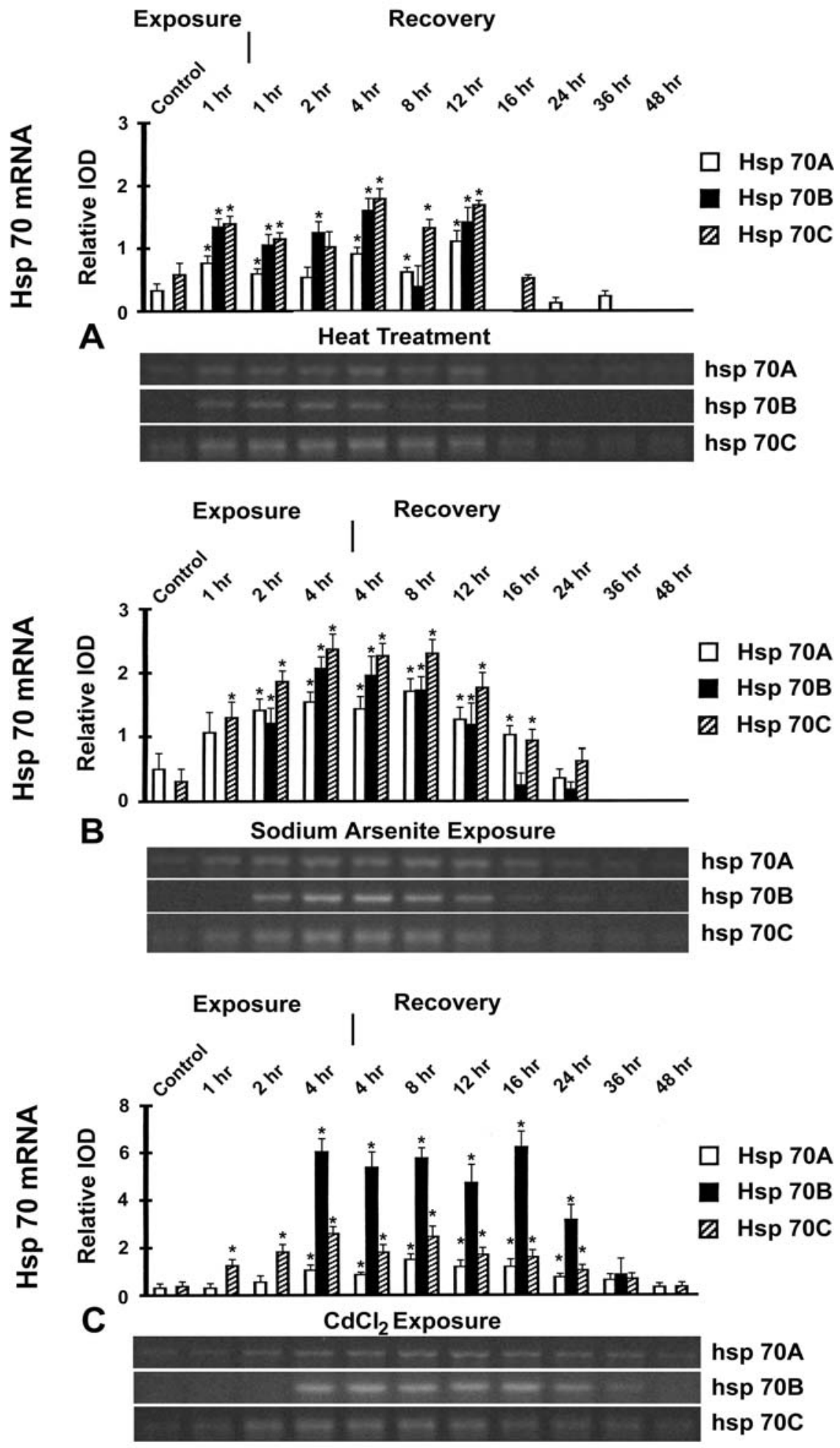

Figure 6. RT-PCR analysis of hsp 70 mRNA in HK-2 cells. Relative IOD of bands representing hsp 70A, 70B, 70C mRNA for HK-2 cells exposed to heat shock (A), sodium arsenite (B), or $\mathrm{CdCl}_{2}(\mathrm{C})$. Asterisk indicates significant difference (at 0.05 or below) compared to control. 
by the treatment with heat, sodium arsenite, or $\mathrm{CdCl}_{2}$. Likewise, expression of mRNA for the hsp 70C gene was elevated in the HK-2 cells as a result of exposure to heat, sodium arsenite, and $\mathrm{CdCl}_{2}$. (Figure $6, \mathrm{~A}-\mathrm{C}$ ). For all 3 agents, hsp 70A, 70B, and 70C mRNAs increased during the exposure period and maintained this increase 12 to 24 hours into the recovery period, returning to control values 36 hours following removal of the agent.

Expression of hsp 27, hsp 60, hsc 70, and hsp 70 mRNA and protein in $\mathrm{HK}-2$ cells exposed to $\mathbf{C d C l}_{2}$ for $\mathbf{1 6}$ days. The expression of hsp 27, hsp 60, hsc 70 , and hsp 70 mRNA and protein were also determined when the HK-2 cells were exposed to $\mathrm{Cd}^{+2}$ for an extended time course. The HK-2 cells were exposed continuously to $\mathrm{Cd}^{+2}$ at three exposure levels over a 16-day time course - $0.9: \mathrm{M}$, which produces no cell death over the 16-day time course; $2.2: \mathrm{M}$, which produces cell death late in the 16-day time course; and $4.5: \mathrm{M}$, which produces cell death early in the 16-day time course (Figure 7). The respective mRNA and proteins were determined at $1,4,7,10,13$, and 16 days of the respective time courses, with the effects of $\mathrm{Cd}^{+2}$ on hsp expression being normalized to a control value of 1.0 for data presentation. There was no significant alteration in the levels of the hsp 27 , hsp 60 , and hsc 70 protein at any time point over the 16-day time course for the cells exposed to the 3 concentrations of $\mathrm{CdCl}_{2}$ (Figure 8, A-C). The only exception was for hsp 70 , where the hsp 70 protein was increased at the highest $\mathrm{CdCl}_{2}$ concentration on day 1 and day 4 of the 16-day time course (Figure 8D). Other than these two 


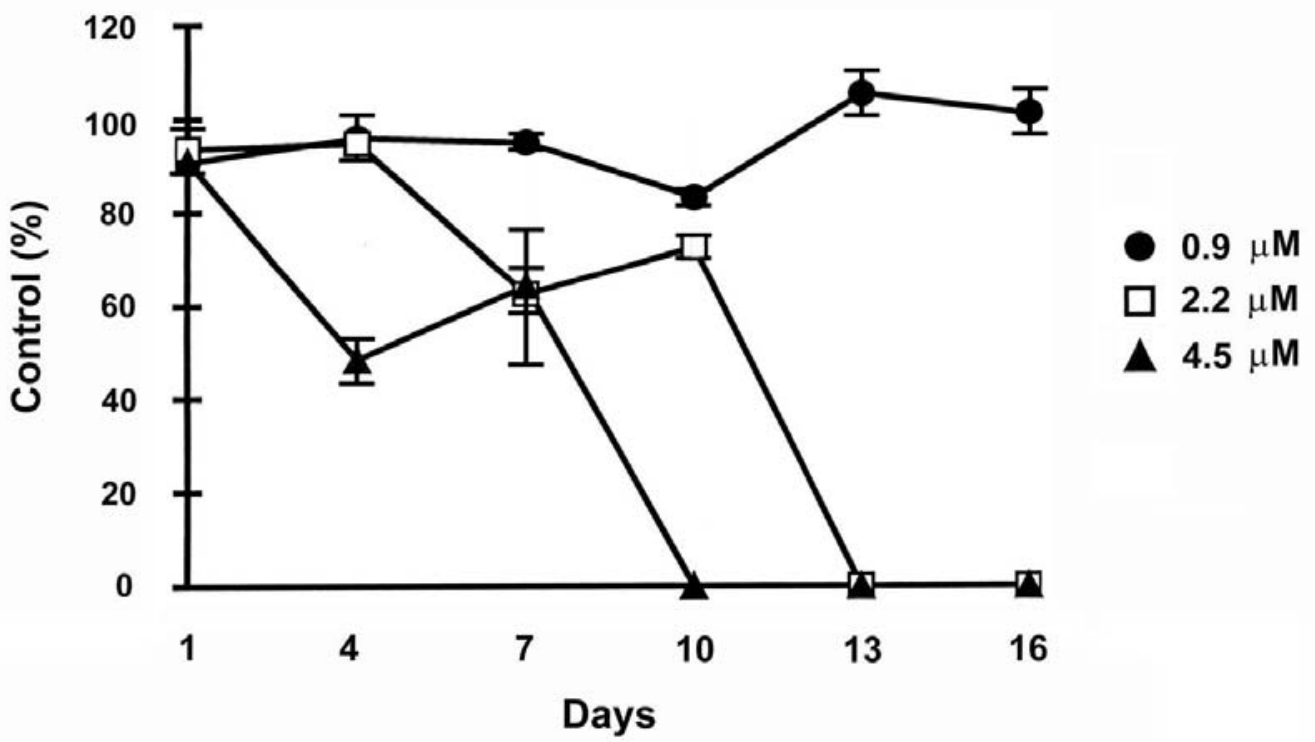

Figure 7. HK-2 cells continuous exposure to $\mathrm{CdCl}_{2}$. $\mathrm{HK}-2$ cells were exposed to $0.9,2.2$, and $4.5: \mathrm{M} \mathrm{CdCl}_{2}$ for a period of 16 days. Computer-assisted cell counts are shown for the HK-2 cells. DAPI stained nuclei in 20 fields for each triplicate well were counted, and results are expressed as percentage of control. 

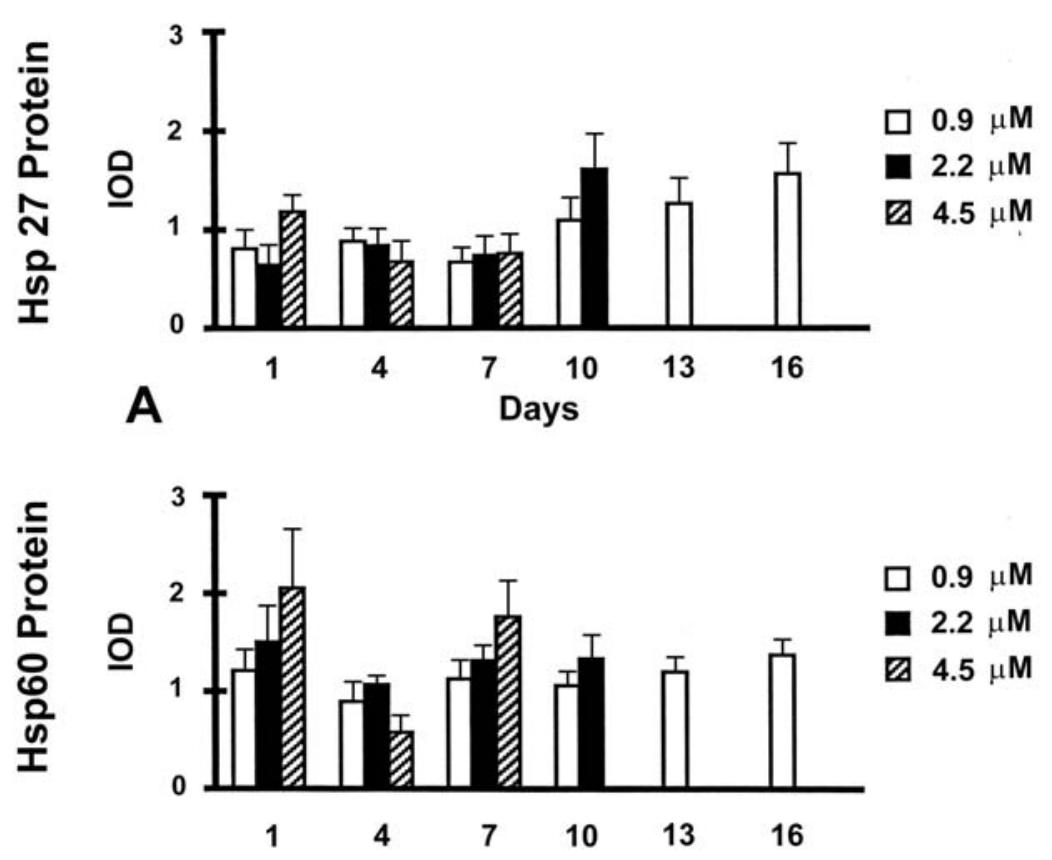

B

Days
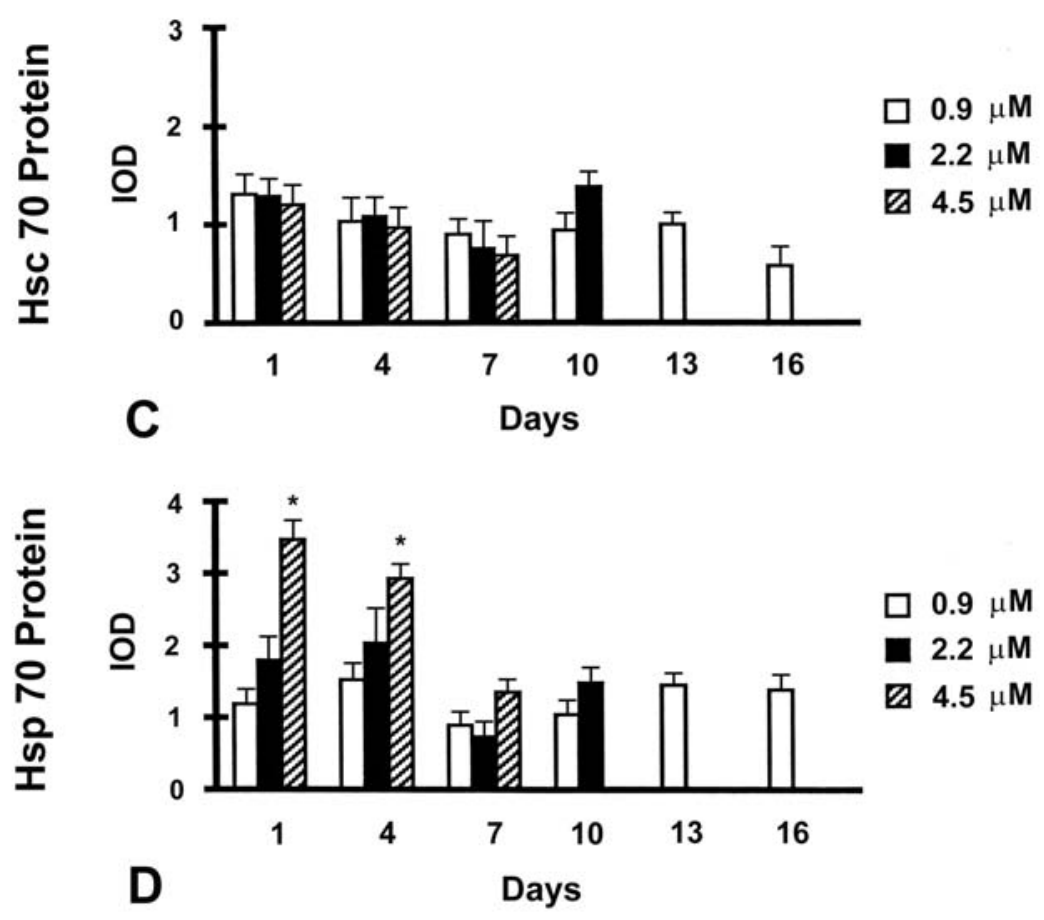

Figure 8. Expression of heat shock proteins in HK-2 cells continuously exposed to $0.9,2.2$, and $4.5 \mu \mathrm{M} \mathrm{CdCl}_{2}$ for a period of 16 -days. IOD of bands representing hsp 27 (A), hsp 60 (B), hsc 70 (C), and hsp 70 (D) protein in $\mathrm{Cd}^{+2}$ treated cells. The OD for each hsp band was determined and the result normalized to a control value of 1.0 for cells exposed to $\mathrm{CdCl}_{2}$. There were no significant differences compared to the control. 

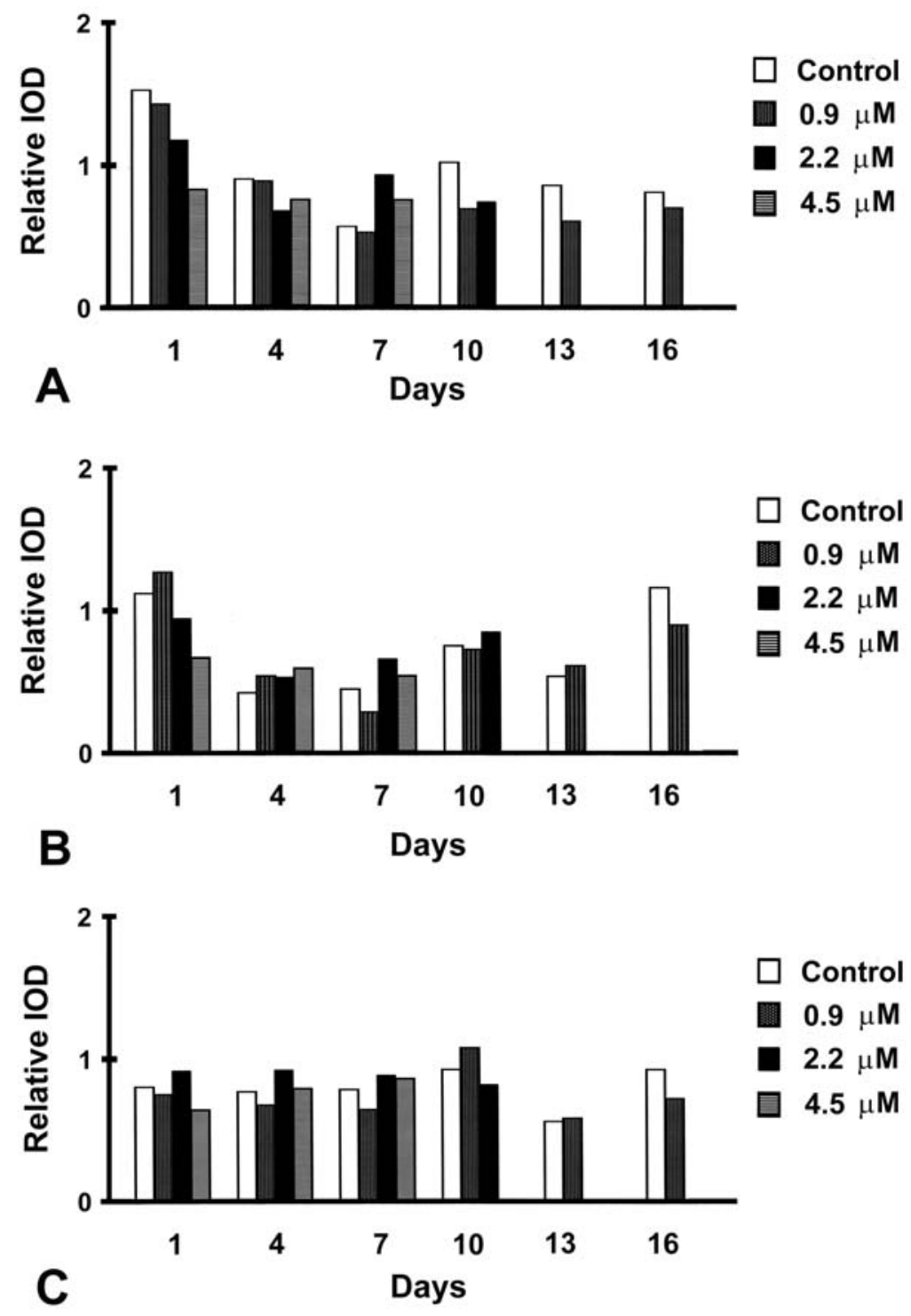

Figure 9. Expression of hsp mRNAs in HK-2 cells continuously exposed to 0.9, 2.2, and $4.5 \mu \mathrm{M} \mathrm{CdCl}$ for a period of 16-days. Relative IOD of bands representing hsp 27 (A), hsp 60 (B), hsc 70 (C) mRNA in $\mathrm{Cd}^{+2}$ treated cells. There were no significant differences compared to the control. 

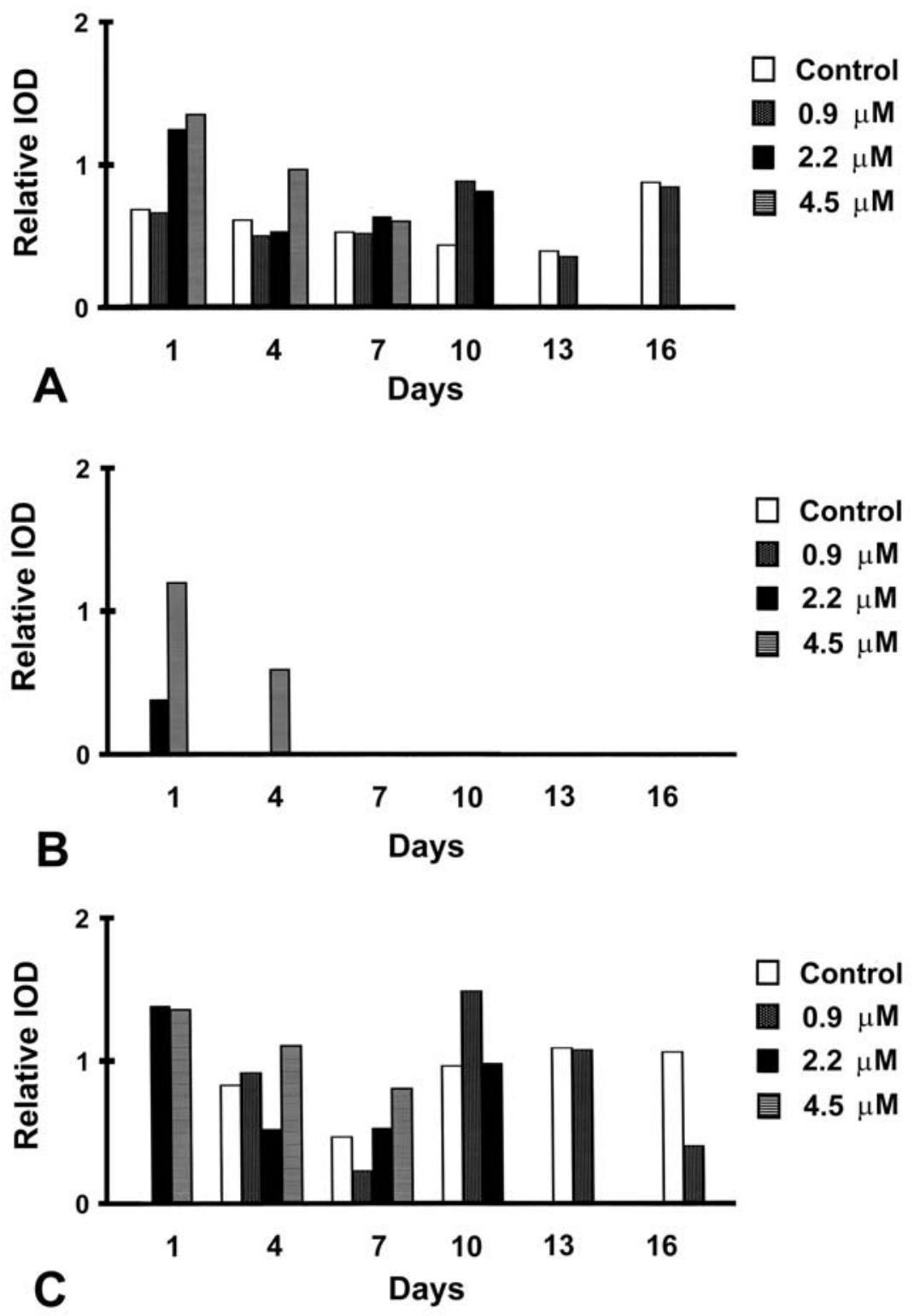

Figure 10. Expression of hsp mRNAs in HK-2 cells continuously exposed to 0.9, 2.2, and $4.5 \mu \mathrm{M} \mathrm{CdCl} 2$ for a period of 16-days. Relative IOD of bands representing hsp 70A (A), hsp 70B (B), hsp 70C (C) mRNA in $\mathrm{Cd}^{+2}$ treated cells. 
time points, $\mathrm{CdCl}_{2}$ had no effect on the level of expression of hsp 70 at both lethal and sublethal levels of exposure.

There was no change in the expression of hsp 27, hsp 60, and hsc 70 mRNA in the HK-2 cells at any of the $3 \mathrm{CdCl}_{2}$ concentrations over the 16-day time course (Figure 9). There was also no change in the level of hsp 70A, 70B, 70C mRNA over the 16-day time course for the HK-2 cells exposed to the low and intermediate levels of $\mathrm{CdCl}_{2}$ (Figure 10). At the highest level of $\mathrm{CdCl}_{2}$ exposure, there was an increase in mRNA for the hsp 70A gene on day 1 and 4, for the hsp 70B gene on day 1 , and for the hsp $70 \mathrm{C}$ gene on day 1 (Figure 10). Otherwise, these mRNAs remained at control levels.

\section{DISCUSSION}

The kidney and in particular the proximal tubule represent the organ and cell type that are critically affected by chronic exposure to cadmium in both animals and humans $(5,6,7,8,9)$. One means to study the interaction of cadmium with the proximal tubule cell of the kidney is to utilize a cell culture model of the HPT cells that retains many of the differentiated features expected of this segment of the nephron $(10,11,12)$. When the HPT cells were exposed to environmentally significant concentrations of $\mathrm{Cd}^{+2}$, alterations in cell structure and function were demonstrated that were similar to those known to occur in situ in the kidneys of animal models and humans $(13,14,15)$. These alterations included loss of microvilli structure, disorganization of lateral membrane interdigitation, pyknotic nuclei, loss of transport function, and loss of the ability of the cells to regenerate when 
exposed to low dosages of $\mathrm{Cd}^{+2}$. This indicated that $\mathrm{Cd}$-induced nephrotoxicity could be modeled in this culture system by exposure of the cells to $\mathrm{Cd}^{+2}$. Recent studies have defined the expression of the heat-shock proteins when the cells were exposed to heat, sodium arsenite, or $\operatorname{CdCl}_{2}(1,2,3)$. While these studies define the value of the model system for studies of the stress response, there are limitations to the use of a mortal cell culture model. Foremost among these is that stable transfection cannot be used to alter gene expression due to the mortal nature of the cells. Other limitations include the difficulty most investigators have in procurement of human tissue and, instead of laboratory-based isolation, the high commercial cost of the cells. Thus, the major goal of this study was to determine if the immortalized HK-2 human proximal tubule cell line could provide an easy to use model system to study the stress response of the proximal tubule cell. A comparison of the HK-2 and HPT cell response to stress was used as a test system to determine if the basic features of the heat shock response by heat, sodium arsenite, and cadmium were similar for the two models.

In previous studies with the HPT cells, both hsp 27 mRNA and protein were shown to be readily induced by heat shock, sodium arsenite, or $\mathrm{CdCl}_{2}$ (1). The inductions were rapid following treatment with the stimulus and extended well into the recovery period. Maximal inductions of 6 - to 10 -fold for hsp 27 mRNA and 4- to 7-fold for the hsp 27 protein were obtained depending on the stimulus. In contrast, hsp 27 mRNA and protein were induced in the HK-2 cells by these agents but with a maximal induction of only 2 - to 3 -fold at best at any time point to any given treatment. Thus, there was a clear difference between the HPT cells and the HK-2 
cells in their ability to induce the expression of hsp 27 mRNA and protein in response to either physical or chemical stress. An examination of the basal levels of hsp 27 mRNA and protein expression between the two cell culture models suggested that the basis for this difference might be that the HK-2 cells already possess higher basal levels of hsp 27. To detect basal hsp 27 mRNA in the HPT cells required a $500 \mathrm{ng}$ input of total RNA and 27 PCR cycles; whereas to detect hsp 27 mRNA in the HK-2 cells required only 20 PCR cycles at an identical total RNA input. This would indicate that the basal levels of hsp 27 mRNA in the HK-2 cells were substantially higher than those in the HPT cells. This finding was also true for the expression of the hsp 27 protein. Although hsp 27 protein was detected by Western analysis in the HPT cell extracts using a $5 \mu \mathrm{g}$ protein input, only a $2 \mu \mathrm{g}$ input was required for the HK-2 cells. These results suggest that the failure of the HK-2 cells to increase hsp 27 levels in response to physical and chemical stress is because they already possess elevated basal levels of hsp 27 mRNA and protein. However, it is not clear yet how the elevated basal levels of hsp 27 control hsp 27 levels in HK-2 cells by stress. Hsp 27 is also phosphorylated at serine residues in response to heat shock, mitotic stimuli, and other stresses, suggesting a role for hsp 27 in the regulation of signal transduction pathways $(1,16)$. This response remained intact in the HK-2 cells, as noted by an increase in the phosphorylation of hsp 27 when the cells were exposed acutely to heat, sodium arsenite, or $\mathrm{CdCl}_{2}$.

This possibility was reinforced by a comparison of the expression patterns of hsp 60 in the HK-2 cells to those obtained previously in the HPT cells. In the HK-2 cells, exposure to heat or $\mathrm{CdCl}_{2}$ had no effect on the levels of hsp 60 mRNA 
levels at only two time points. In contrast, all three agents were shown to readily induce both hsp 60 mRNA and protein in HPT cells under identical conditions (3). Similar to that found for hsp 27, the basal levels of hsp 60 expression were much higher in the HK-2 than HPT cells. Although no other studies could be found where the stress response has been compared between a mortal cell culture and its nontumorigenic immortalized counterpart, there is one study in the literature that shows that the basal expression of some stress response proteins is elevated in cancer cell lines when compared to the normal counterpart (17). In this study, it was shown that there was a 3- to 5-fold increase in the basal level of GRP 94, a glucose-regulated protein, in 5 breast carcinoma cell lines when compared to normal breast epithelial cell lines. A 1.5- to 3-fold increase was also found for GRP 78 in 4 of the 5 breast cancer cell lines. Furthermore, the overexpression of hsp 27 has also been shown to occur in many cancers and in breast cancer to be associated with a poor prognosis in a subset of these patients (18). The overexpression of hsp 27 has also been shown to influence invasiveness and motility of breast cancer cell lines (19). Together, these findings suggest that one or more of the genetic events that resulted in the immortalization of the HK-2 cells also elicited an increase in basal hsp 27 and hsp 60 expression similar to that found in the normal parent cells under stress conditions.

In the HK-2 cells the basal levels of hsp 70 expression were similar to those found in the HPT cells, and a marked induction of hsp 70 mRNA and protein occurred in both the HK-2 and HPT cells upon treatment with both physical and chemical stress. The only difference between the cell lines was that the hsp 70 
mRNA and protein response, while identical for both heat and sodium arsenite exposure, was induced to a greater degree by $\mathrm{CdCl}_{2}$ in the HK-2 cells than in the HPT cells. The reason why the basal levels of hsp 27 and hsp 60 increased and why that of hsp 70 did not is questionable.

This study demonstrates that there are both similarities and differences between the HK-2 and HPT cell lines when exposed to physical and chemical stress. A similarity is that both cell lines express the same stress-response proteins under basal conditions. However, the differences found in the basal and induced expression of hsp 27 and hsp 60 between the cell lines would indicate that the HK-2 cells used alone would not be a good model to define the mechanisms underlying induction of these proteins. However, these very limitations can render the HK-2 a valuable adjunct for comparative studies between the two cell lines. Having the two cell lines allows the HPT to be used to define the mechanisms involved in upregulation of the hsp 27 and hsp 60 stress response and the HK-2 to be used to define what returns the elevated levels to the normal inducible state. A similar usage would also be possible to study the differences in hsp 70 regulation when the cells are exposed to $\mathrm{Cd}^{+2}$. Thus, although there are differences in the regulation of the stress response between the two cell lines, as long as these differences are recognized, the HK-2 cell line should be a valuable adjunct to study the stress response of the proximal tubule in general and when exposed to environmental pollutants such as cadmium. 


\section{REFERENCES}

1. Somji, S., Sens, D. A., Garrett, S. H., Sens, M. A., and Todd, J. H. Heat shock protein 27 expression by human proximal tubule cells exposed to lethal and sublethal concentrations of $\mathrm{CdCl}_{2}$. Environ. Health Persect. 107:545-552, 1999.

2. Somji, S., Todd, J. H., Sens, M. A., Garrett, S. H., and Sens, D. A. Expression of the constitutive and inducible forms of heat shock protein 70 in human proximal tubule cells exposed to heat, sodium arsenite and $\mathrm{CdCl}_{2}$. Environ Health Perspect. 107:887-894, 1999.

3. Somji, S., Todd, J. H., Sens, M. A., Garrett, S. H., and Sens, D. A. Expression of heat shock protein 60 in human proximal tubule cells exposed to heat, sodium arsenite, and $\mathrm{CdCl}_{2}$. Toxicol. Lett. 115:127-136, 2000.

4. Ryan, M. J., Johnson, G., Kirk, J., Fuersenberg, S. M., Zager, R. A., and Torok-Storb, B. HK-2: An immortalized proximal tubule epithelial cell line from normal adult human kidney. Kidney Int. 45:48-57, 1994.

5. Bernard, A., Roels, H., Hubermont, G., Buchet, J. P., Masson, P. L., and Lauwerys, R. Characterization of the proteinuria in Cd exposed workers. Int. Arch. Occup. Environ. Health 38:19-30, 1976.

6. Lauwerys, R., Buchet, J. P., Roels, H., Brouwers, J., and Stanescu, D. Epidemiological survey of workers exposed to cadmium: effect of lung, kidney and several biological indices. Arch. Environ. Health 28:145-148, 1974.

7. Kido, T., Honda, R., Tsuritani, I., Yamada, H., Ishizaki, M., Yamada, Y., and Nogawa, K. Progress of renal dysfunction in inhabitants environmentally exposed to cadmium. Arch. Environ. Health 43:231-217, 1988. 
8. Gonich, H. C., Indraprasit, S., Rosen, V. J., Neustein, H., Van de Velde, R., and Raghavan, S. R. V. Effect of cadmium on renal tubular function, the ATPNa-ATPase transport system and renal tubular ultrastructure. Mineral Electrol. Metab. 3:21-35, 1980.

9. Bosco, E., Porta, N., and Diezi, J. Renal handling of cadmium: A study by tubular microinjections. Arch. Toxicol. 7:371-373, 1986.

10. Detrisac, C. J., Sens, M. A., Garvin, A. J., Spicer, S. S., and Sens, D. A. Tissue culture of human kidney epithelial cells of proximal tubule origin. Kidney Int. 25:383-390, 1984.

11.Todd, J. H., McMartin, K., and Sens, D. A. Enzymatic isolation and serumfree culture of human renal cells retaining properties of proximal tubule cells. In Methods in molecular biology. Human cell culture protocols, ed. G. E. Jones, pp. 431-436. Clifton, NJ:Humana Press.

12. Sens, D. A., Detrisac, C. J., Sens, M. A., and Todd, J. H. Tissue culture of human renal epithelial cells using a defined serum-free growth formulation. Exp. Nephrol. 7:344-352, 1999.

13. Hazen-Martin, D. J., Sens, D. A., Blackburn, J. G., and Sens, M. A. Cadmium nephrotoxicity in human proximal tubule cell cultures. In Vitro 25:784-790, 1989.

14. Hazen-Martin, D. J., Sens, D. A., Blackburn, J. G., Flath, M. C., and Sens, M. A. An electrophysiological and freeze fracture assessment of cadmium nephrotoxicity in vitro. In Vitro 25:791-799, 1989. 
15. Hazen-Martin, D. J., Todd, J. H., Sens, M. A., Khan, W., Bylander, J. E., Smyth, B. J., and Sens, D. A. Electrical and freeze-fracture analysis of the effects of ionic cadmium on the cell membrane of human proximal tubule cells. Environ. Health Perspect. 101:510-516, 1993.

16. Macario, A. J. L. Heat-shock proteins and molecular chaperones; Implications for pathogenesis, diagnostics, and therapeutics. Int. J. Clin. Lab. Res. 25:5970,1995 .

17.Gazit, G., Lu, J., and Lee, A. S. De-regulation of GRP stress protein expression in human breast cancer cell lines. Breast Cancer Res. Treat. $54: 135-146,1999$.

18. Oesterreich, S., Hilsenbeck, S. G., Ciocca, D. R., Allred, C. D., Clark, G. C., Chamness, G. C., Osborne, C. K., and Fuqua, S. A. W. The small heat shock protein hsp 27 is not an independent prognosis marker in axillary lymph nodenegative breast cancer patients. Clin. Cancer Res. 2:1199-1206, 1996.

19. Lemieux, P., Oesterreich, S., Lawrence, J. A., Steeg, P. S., Hilsenbeck, S. G., Harvey, J. M., and Fuqua, S. A. W. The small heat shock protein hsp 27 increases invasiveness but decreases motility of breast cancer cells. Invasion Metastasis 17:113-123, 1997. 


\section{TRANSIENT INDUCTION OF METALLOTHIONEIN ISOFORM 3 (MT-3), c-fos, c-jun AND c-myc IN HUMAN PROXIMAL TUBULE CELLS EXPOSED TO CADMIUM ${ }^{1}$}

1 The contents in this chapter were published in January 2002 in Toxicology Letters 126:69-80. 


\section{INTRODUCTION}

A recent study demonstrated that MT-3 could be detected in total RNA isolated from human kidney tissue and cell cultures derived from the human proximal tubule (HPT; 1). The presence of the MT-3 protein in the proximal tubules of the in situ human kidney was subsequently confirmed by immunolocalization using an antibody directed against the human MT-3 protein $(2,3)$. The finding that MT-3 was expressed in the human kidney was unexpected because the MT-3 isoform had been reported to be a brain-specific member of the MT gene family (4). This unexpected expression of MT-3 in the human kidney, and its expression in the proximal tubule in particular, leads to understand the mechanism responsible for the chronic nephrotoxicity that is produced in the kidney by the heavy metal pollutant, $\mathrm{Cd}^{+2}$. This is due to the fact that numerous studies in both animals and humans have shown that the kidney, and the proximal tubule, are the organ and cell type critically affected by chronic exposure to $\mathrm{Cd}^{+2}(5,6,7,8)$. Since MT-3 is also able to bind and sequester $\mathrm{Cd}^{+2}$ similar to that of the MT-1 and MT-2 isoforms, it would also have the potential to play a role in mediating the toxicity that $\mathrm{Cd}^{+2}$ elicits on the renal proximal tubule cell. The overall goals of this chapter were to confirm basal expression of MT-3 in the proximal tubules of the adult human kidney and the cell culture, and to define the expression of MT-3 in mortal human proximal tubule cells and immortal HPT cell line (HK-2) when exposed to lethal and sublethal concentrations of cadmium under both acute and chronic time periods of exposure. 


\section{RESULTS}

\section{Basal expression of MT-3 mRNA in the human proximal tubule and}

confluent cultures of HPT and HK-2 cells. The basal expression of MT-3 mRNA in the proximal tubule of the in situ kidney was determined by RT-PCR on total RNA isolated from proximal tubules microdissected from formalin-fixed kidney sections. The proximal tubules for microdissection were identified based on periodic-acid-Schiff (PAS) staining of serial sections and the corresponding H\&E stained proximal tubules removed for analysis (Figure $11 \mathrm{~A}$ and $\mathrm{B}$ ). The results of this analysis demonstrated that the in situ proximal tubule expressed a high basal level of MT-3 mRNA as judged by a relative comparison to the \$-actin housekeeping gene (Figure 12). Using the same sample of total RNA from the microdissected proximal tubules, MT-3 mRNA expression could be determined at 40 PCR cycles and a 500 ng total RNA input, whereas, a second nested PCR had to be performed to demonstrate the expression of \$-actin. This would indicate that the relative expression of MT-3 mRNA was much higher than that of the housekeeping gene. The basal expression of MT-3 mRNA was also determined on total RNA obtained from confluent cultures of the mortal HPT cells and the immortal HK-2 cell line. It was demonstrated that the HPT cells had moderate expression of MT-3 mRNA could be detected following 35 PCR cycles and a 500 ng total RNA input, while mRNA for the g3pdh housekeeping gene was detected at identical total RNA input (Figure 12). It was demonstrated that HK-2 cells had no expression of MT-3 mRNA at a $500 \mathrm{ng}$ total RNA input and 40 cycles of PCR, but mRNA for the g3pdh housekeeping gene was detected at 25 


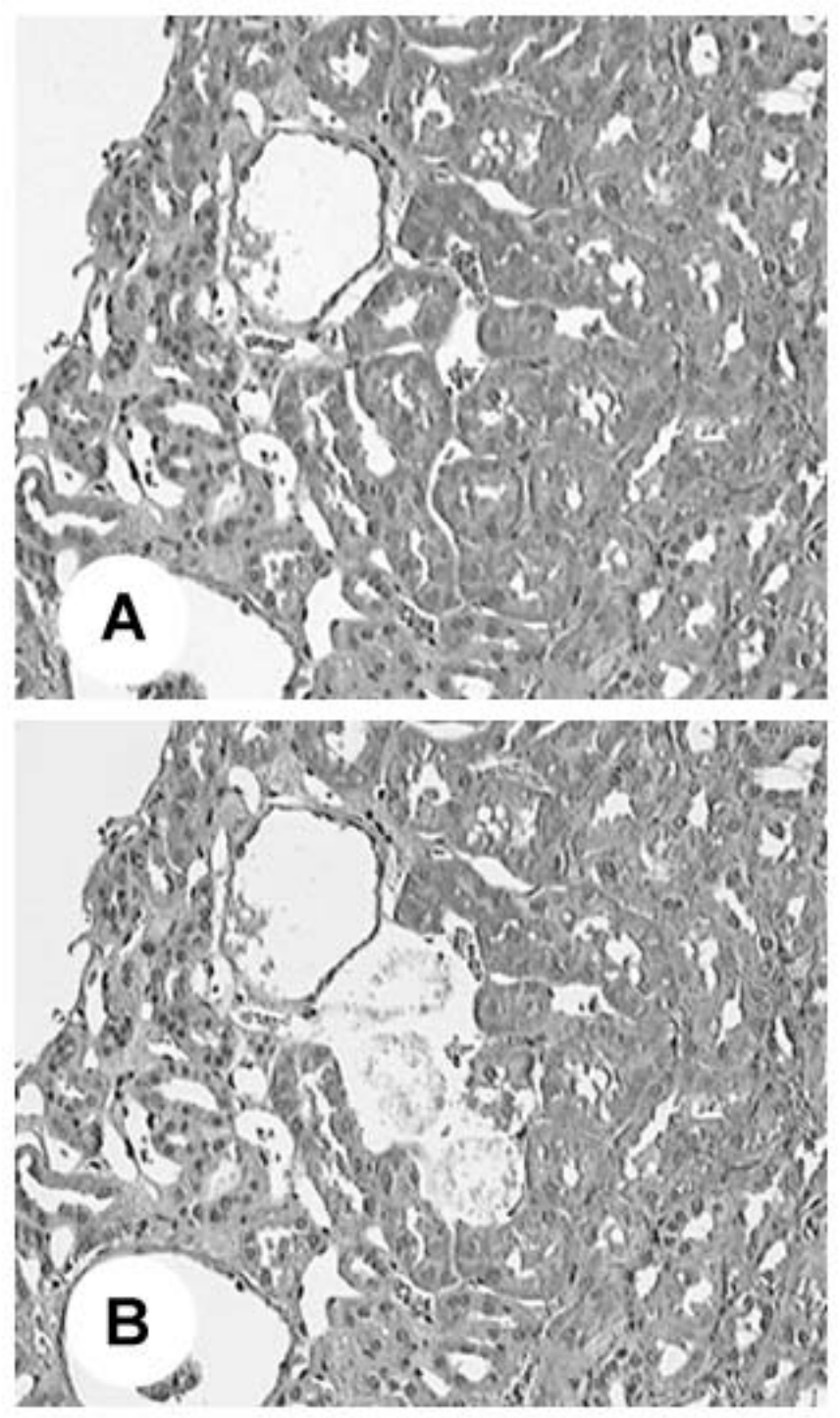

Figure 11. Microdissection of human proximal tubules from adult kidney. Paraffin blocks of formalin fixed tissue from pathology archives were used to obtain sections from disease-free areas of kidneys removed for neoplastic disease. (A) Five micron thick section of kidney stained lightly with hematoxylin and eosin before laser capture. (B) The residual tissue section shown after laser capture. 


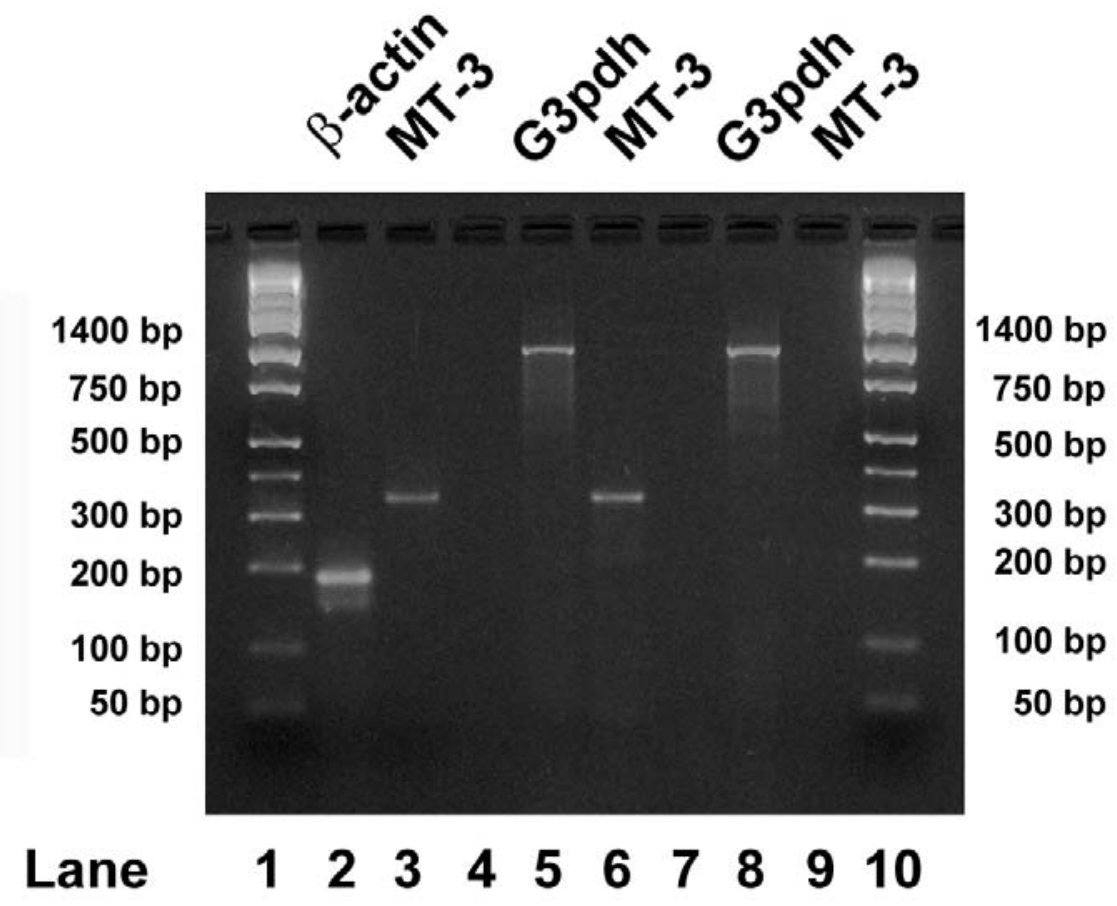

Figure 12. Basal expression of MT-3 in human proximal tubule. Lane 1 and 10. DNA ladder. Lane 2 and 3. RT-PCR was performed on total RNA isolated from microdissected proximal tubules. Bands representing PCR products for \$-actin (nested) (194 bp) and MT-3 (325 bp) are shown. Lanes 5 and 6. RT-PCR was performed on total RNA ( $500 \mathrm{ng}$ ) isolated from cultured human proximal tubule cells. Bands representing PCR products for GAPDH (983 bp) at 25 PCR cycles and MT-3 at 35 PCR cycles are shown. Lanes 8 and 9. RT-PCR was performed on total RNA isolated from the cell line HK-2. Band representing PCR product for GAPDH at 25 cycles is shown. No PCR product was detected for MT-3 in HK-2 cells at an RNA input of $500 \mathrm{ng}$ and 40 PCR cycles. 
PCR cycles using the same total RNA sample (Figure 12). The average basal expression of MT-3 protein in the 3 isolates of HPT cells was $0.51 \pm 0.04$ ng MT3 per : $g$ total protein. The MT-3 protein was below the limit of detection in the HK-2 cells.

Expression of MT-3 mRNA and protein as a function of HPT cell growth. The basal level of expression of MT-3 mRNA and protein for a long term period was determined during HPT cell growth and when the cells were maintained at confluence. This was accomplished by determining the MT-3 mRNA (relative to g3pdh) and protein levels on HPT cells that had been maintained at confluence for 7 days and then subcultured at a 1:3 ratio and determining cell growth, MT-3 mRNA and MT-3 protein each day for a 30 day period (Figure 13A, B, C). Following subculture, the HPT cells attained confluence within 5 days and maintained a constant cell number for 25 additional days (Figure 13A). The level of MT-3 mRNA was reduced 10-fold following subculture and remained reduced for the next 5 days following subculture (Figure 13B). On day 6 following subculture, the level of MT-3 mRNA increased significantly to a level similar to that which preceded subculture of the cells and remained elevated and close to this original level for the remaining 24 days of the time course (Figure 13B). In general, the level of MT-3 protein followed that of MT-3 mRNA, with a significant reduction in MT-3 protein level following subculture and a return to pre-subculture levels by day 6 of the time course (Figure 13C). Therefore, basal level of MT-3 expression was significantly increased after HPT cells were maintained at confluence. 
A

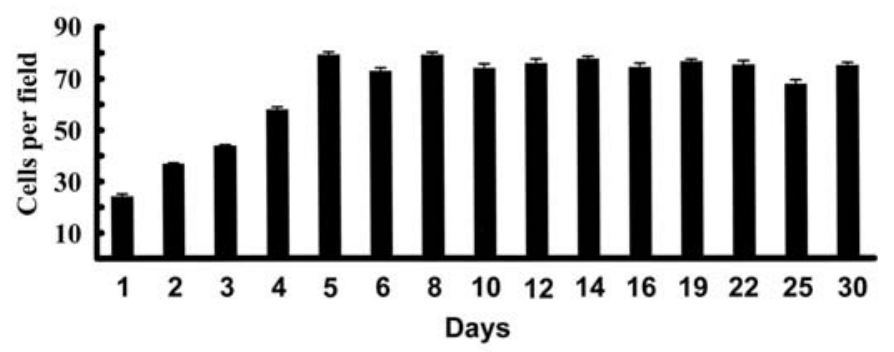

B
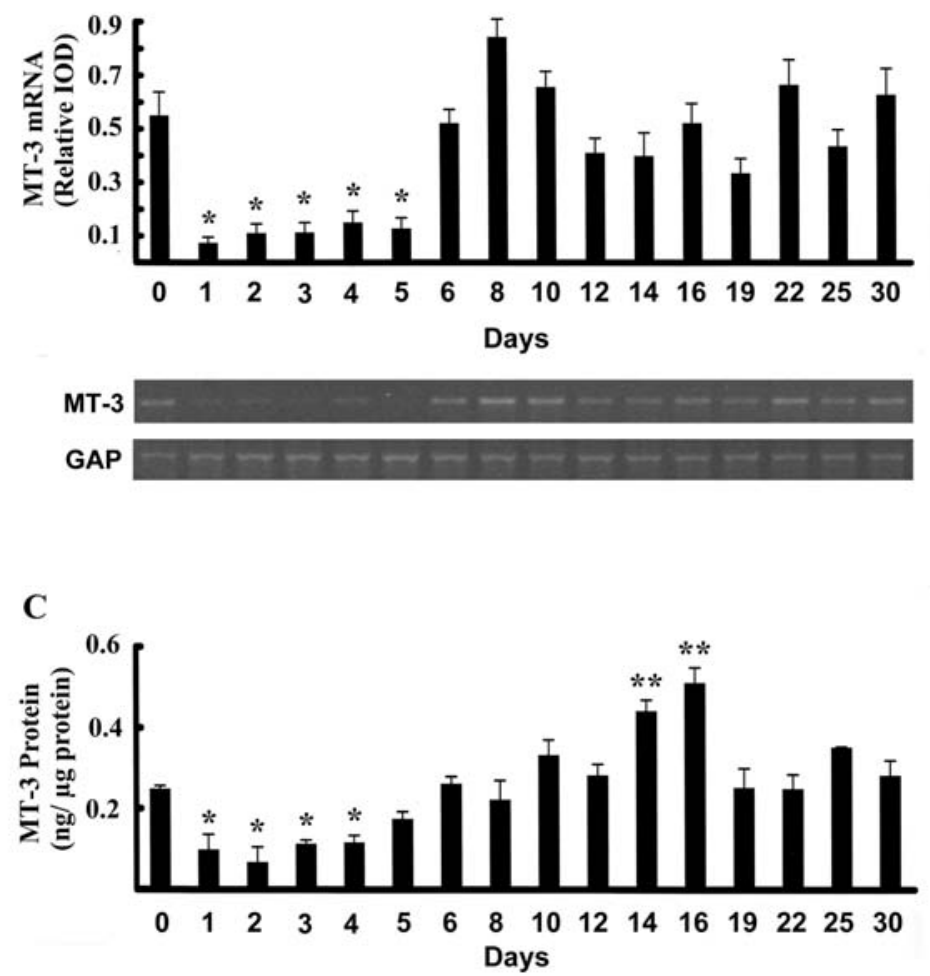

Figure 13. Expression of MT-3 as a function of cell growth. HPT cells were seeded at a ratio of 1:3 in 6-well plates and harvested at the indicated number of days after seeding. Day 0 represents cells taken before seeding. (A) Cell number reported as DAPI-stained nuclei per field. (B) MT-3 mRNA expression assessed by RT-PCR with gene specific primers. The integrated optical density (IOD) of the 40 cycle PCR DNA product band on ethidium bromide stained agarose gels was normalized to that obtained for GAPDH at 30 cycles. (C) MT-3 protein expression. Protein extracts were prepared from cells harvested on the indicated days and assessed for levels of MT-3 protein by immuno-dot blot using an MT-3 specific antibody. Shown are the means and SE of triplicate cell samples. Statistically significant decrease, ${ }^{*}(p<0.01)$, statistically significant increase, ${ }^{*}$ $(p<0.01)$. 


\section{Expression of MT-3 mRNA and protein in confluent HPT cells}

exposed to $\mathrm{Cd}^{+2}$. To expand upon the previous observation that there was a transient increase in MT-3 mRNA when the HPT cells were exposed to $\mathrm{Cd}^{+2}(1)$ and to extend the analysis to the MT-3 protein, the initial experiments were designed to determine if the induction of MT-3 following $\mathrm{Cd}^{+2}$ exposure demonstrated a pattern similar to that expected from the study of the widely studied superfamily of proteins referred to as the heat shock or stress response proteins. Treatment of the HPT cells with $53.4: \mathrm{M} \mathrm{Cd}^{+2}$ for 4 hours, followed by a recovery period where the metal is removed, induced the synthesis of both mRNA and protein for the hsp 27 , hsp 60 , and hsp 70 stress proteins $(9,10,11)$. An identical time course and exposure to $\mathrm{Cd}^{+2}$ was applied to determine if these conditions would also induce the synthesis of MT-3 mRNA and protein. It was demonstrated that following a 4 hour exposure to $\mathrm{Cd}^{+2}$ that MT-3 mRNA was increased 4-fold (Figure 14A). This increase in MT-3 persisted for 24 hours following removal of the metal, before returning to control values after an additional 24 hours in the absence of metal exposure (Figure 14A). In contrast, MT-3 protein was not increased at any time point during $\mathrm{Cd}^{+2}$ exposure or recovery (Figure 14B). It might be possible that acute exposure to $\mathrm{Cd}^{+2}$ and recovery were insufficient to activate the protein synthesis of MT-3, even though the message of MT-3 increased. To further define under what conditions both MT-3 mRNA and protein would be increased by $\mathrm{Cd}^{+2}$ exposure, a second time course was performed where the HPT cells were exposed continuously to 9, 27, $45: \mathrm{M} \mathrm{Cd}^{+2}$ for 48 hours. It was shown that $9: \mathrm{M} \mathrm{Cd}^{+2}$ did not induce MT-3 


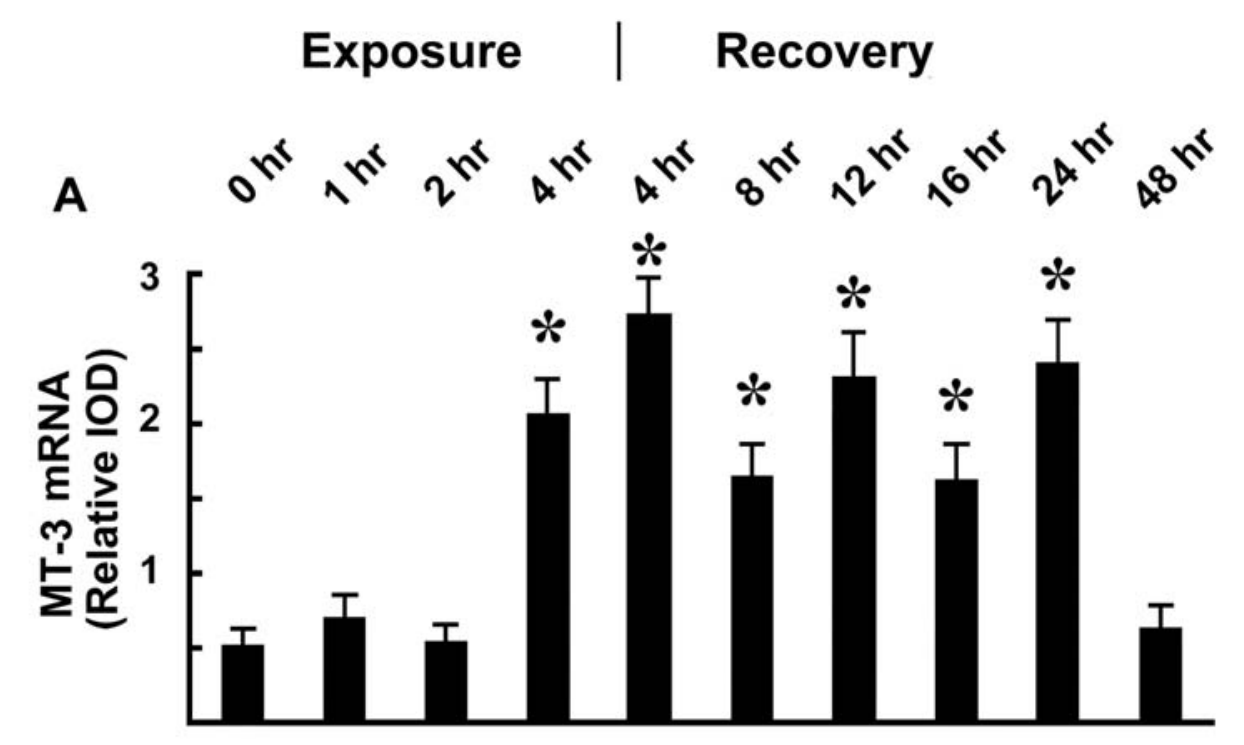

\begin{tabular}{l|l|l}
$B \quad$ Exposure & Recovery
\end{tabular}

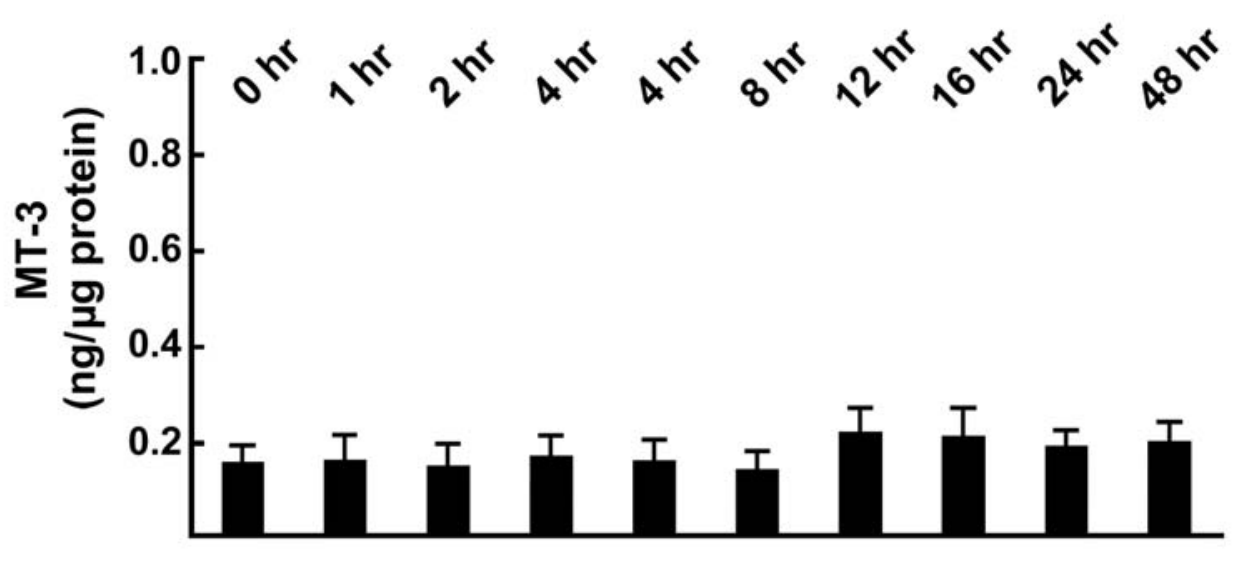

Figure 14. Expression of MT-3 in HPT cells acutely exposed to $\mathrm{Cd}^{+2}$. HPT cells were exposed to $53.4: \mathrm{M} \mathrm{Cd}^{+2}$ for 4 hours followed by recovery in normal growth medium. Cells were harvested for RNA and protein at the indicated time points. (A) Messenger RNA expression assessed by RT-PCR and reported as relative IOD (IOD of the MT-3 RT-PCR product band at 40 cycles normalized to that of G3PDH at 30 cycles). (B) MT-3 protein expression. The levels of MT-3 protein were assessed by an immuno-dot blot procedure using an MT-3 specific antibody. Statistically significant difference from control, ${ }^{*}(p<0.01)$. 
mRNA or protein (Figure $15 \mathrm{~A}$ and $\mathrm{B}$ ). In contrast, the intermediate exposure to $\mathrm{Cd}^{+2}(27: \mathrm{M})$ elicited an increase in MT-3 mRNA following 4-8 hours of exposure (Figure 15A). The level of MT-3 protein was also increased at the intermediate level of $\mathrm{Cd}^{+2}$ exposure, with a peak value at 24 hours of exposure and a return to control values following 48 hours of exposure (Figure 15B). The highest level of $\mathrm{Cd}^{+2}(45: \mathrm{M})$ exposure caused about 15 -fold increase in MT-3 mRNA and a 5fold increase in MT-3 protein following 16 hours of exposure to $\mathrm{Cd}^{+2}$ (Figure 15A and B). Both MT-3 mRNA and protein returned to control values following 48 hours of $\mathrm{Cd}^{+2}$ exposure. To confirm that MT-3 mRNA and protein remained at control values following 48 hours of continuous exposure to sub-lethal and lethal concentrations of $\mathrm{Cd}^{+2}$, the time course was extended to 16 days of continuous exposure (Figure $16 \mathrm{~A}$ and $\mathrm{B}$ ). It was demonstrated that following the initial transient elevation in MT-3 levels noted to occur within the initial 48 hours, further exposure to the three concentrations of $\mathrm{Cd}^{+2}$ failed to elicit an increase in MT-3 mRNA or protein, even though the highest concentration has been shown previously to produce a greater than $50 \%$ loss in cell viability by 7 days of exposure $(12,13)$.

Expression of $c$-fos, $c$-jun, and c-myc mRNA in confluent HPT cells exposed to $\mathrm{Cd}^{+2}$. To elucidate the mRNA expression of early response genes, the effect that acute and extended exposure to $\mathrm{Cd}^{+2}$ had on the expression of $c$ fos, c-jun and c-myc mRNA in the HPT cells was determined using the identical total RNA samples used to determine MT-3 expression. In the acute exposure 

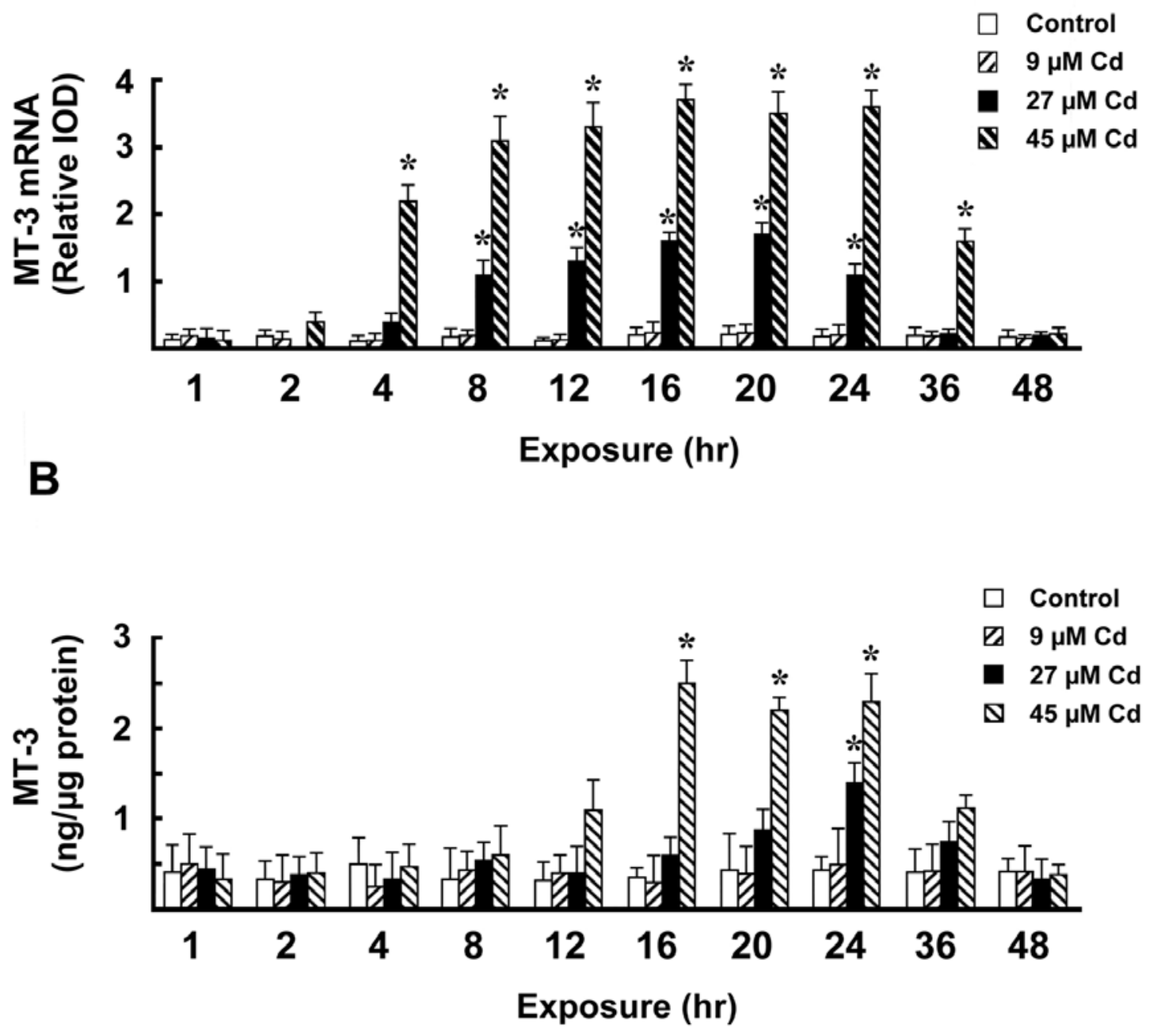

Figure 15. Expression of MT-3 in HPT cells exposed to $\mathrm{Cd}^{+2}$ for 48 hours. HPT cells were exposed to three levels of $\operatorname{Cd}^{+2}(9,27$, and $45: M)$ for up to 48 hours and harvested at the indicated time points. (A) Expression of MT-3 mRNA. The IOD of the MT-3 PCR product normalized to that of GAPDH is shown. (B) MT-3 protein expression. Levels of MT-3 protein were determined using an immunoblot with an MT-3 specific antibody. Statistically significant difference from the control. * $(p<0.01)$ 


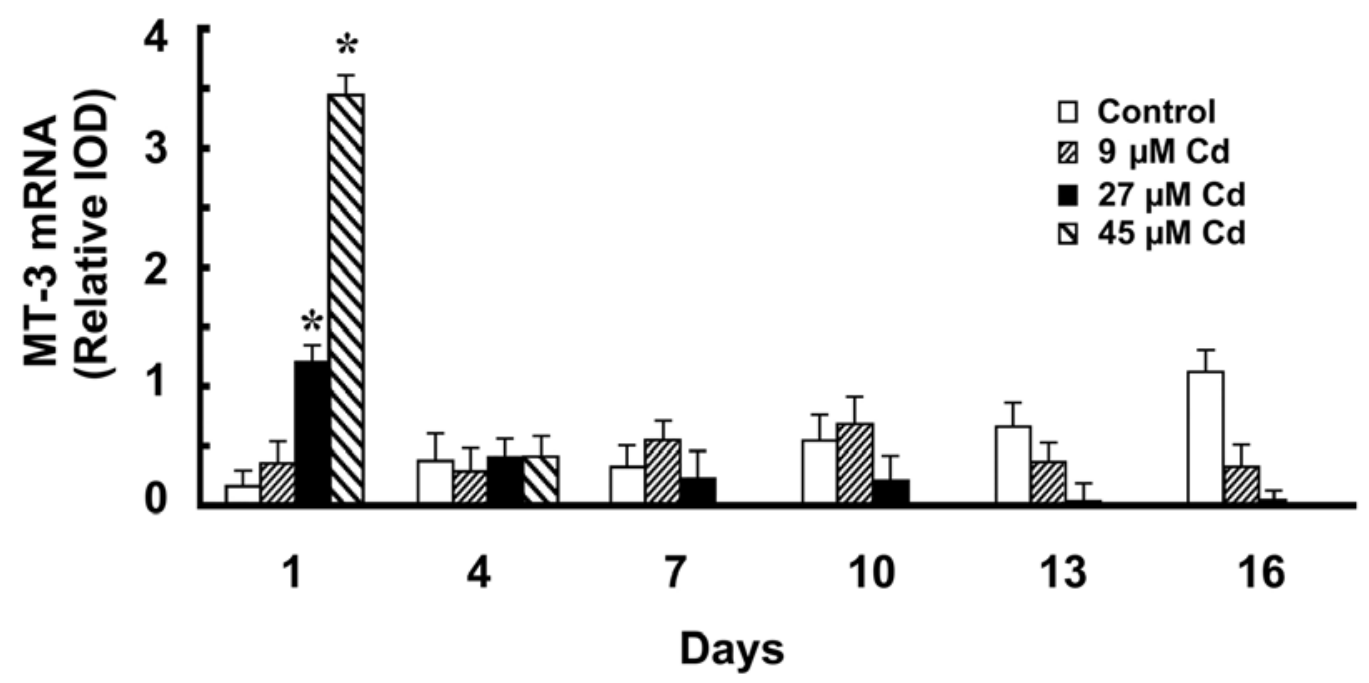

B

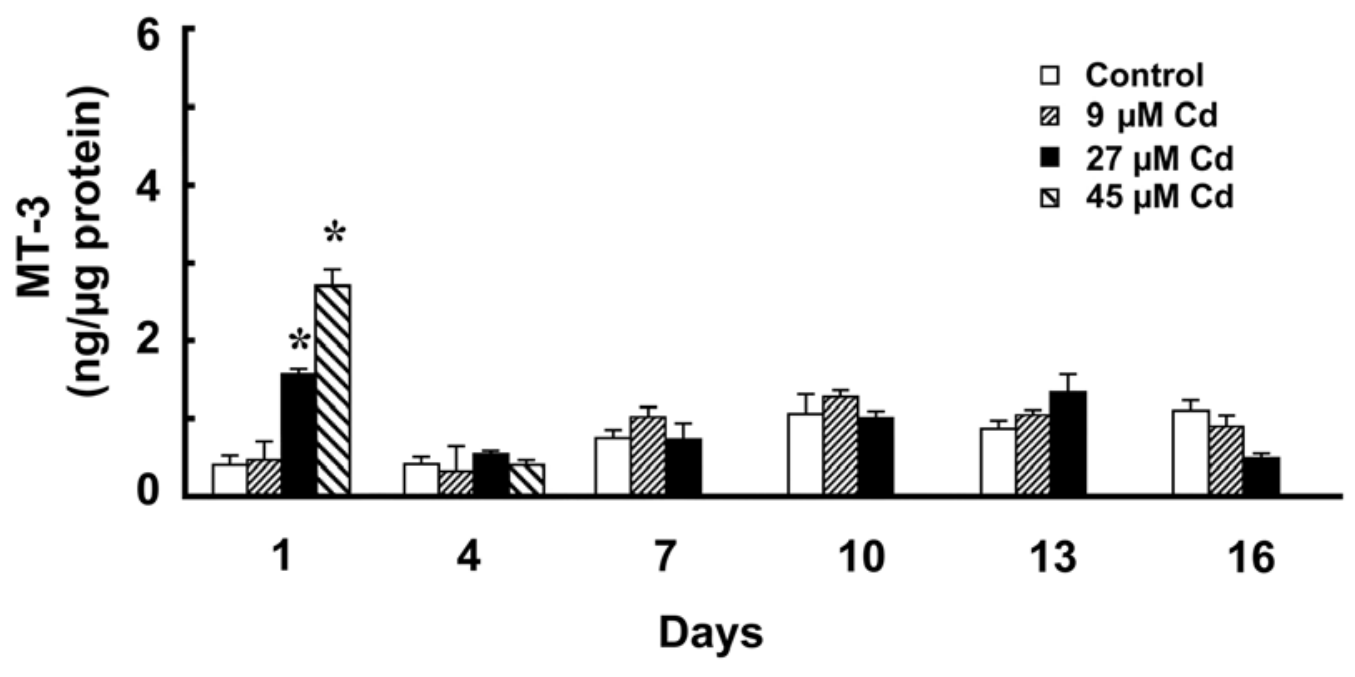

Figure 16. Expression of MT-3 in extended exposure to $\mathrm{Cd}^{+2}$. HPT cells were exposed to three levels of $\mathrm{Cd}^{+2}(9,27,45: \mathrm{M})$ for up to 16 days and harvested at the indicated time points. (A) Expression of MT-3 mRNA. The IOD of the MT-3 PCR product normalized to that of GAPDH is shown. (B) MT-3 protein expression as assessed using an immuno-blot procedure. Statistically significant increase over the daily control. ${ }^{*}(p<0.01)$ 
and recovery experiment, the levels of $c$-fos, $c$-jun and c-myc mRNA were all increased by the 4 hour exposure to $\mathrm{Cd}^{+2}$, and all returned to control values within 48 hours of $\mathrm{Cd}^{+2}$ removal (Figure 17A-C). The mRNA for $c$-fos was just detectable in control cells at 25 PCR cycles, but was markedly elevated within 1 hour of $\mathrm{Cd}^{+2}$ exposure (Figure 17A). The $c$-fos mRNA remained at a maximum elevation for 36 hours following $\mathrm{Cd}^{+2}$ removal and returned to control levels at 48 hours. The mRNA for $c-j u n$ was detected in control cells and was increased approximately 2 -fold following 2 to 4 hours of $\mathrm{Cd}^{+2}$ exposure, with a return to control values within 12 hours of $\mathrm{Cd}^{+2}$ removal (Figure 17B). The mRNA for $c$ myc was also detected in control cells and increased approximately 2-fold following 2 to 4 hours of $\mathrm{Cd}^{+2}$ exposure (Figure 17C). The level of c-myc mRNA returned to control values within 4 hours of $\mathrm{Cd}^{+2}$ removal.

In the continuous exposure of the HPT cells to 9,27 , and $45: \mathrm{M} \mathrm{Cd}^{+2}$ for 48 hours, the levels of $c$-fos, $c$-jun and c-myc mRNA were all increased early in the time course by the intermediate and highest dosage of $\mathrm{Cd}^{+2}$, however, by 36 hours of exposure all three mRNAs had returned to control values (Figure 18AC). The highest level of $\mathrm{Cd}^{+2}$ exposure produced the most marked elevation of all three mRNAs. For $c$-fos, exposure to $45: \mathrm{M} \mathrm{Cd}^{+2}$ resulted in a 2.5 fold increase in mRNA within 1 hour and this level remained elevated for 24 hours before returning to control values (Figure 18A). Twenty seven : $\mathrm{M} \mathrm{Cd}^{+2}$ resulted in a modest increase in c-fos mRNA and a return to a control value within 2 hours. In the $45: \mathrm{M} \mathrm{Cd}^{+2}$ exposure, there was a 2-fold increase in $c-j u n$ mRNA within 1 hour of exposure and a return to the control value by 24 hours (Figure 

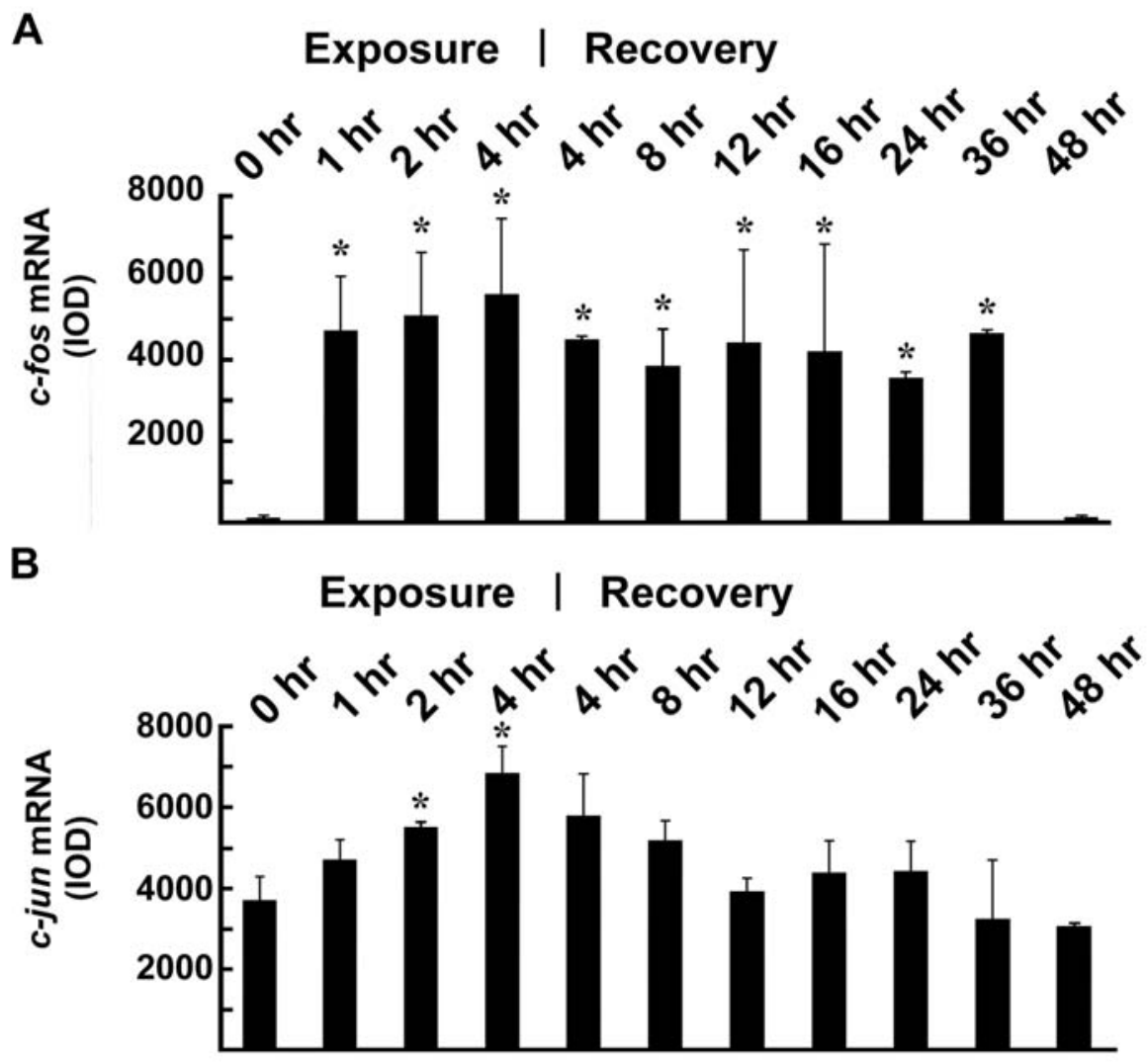

C

\section{Exposure | Recovery}

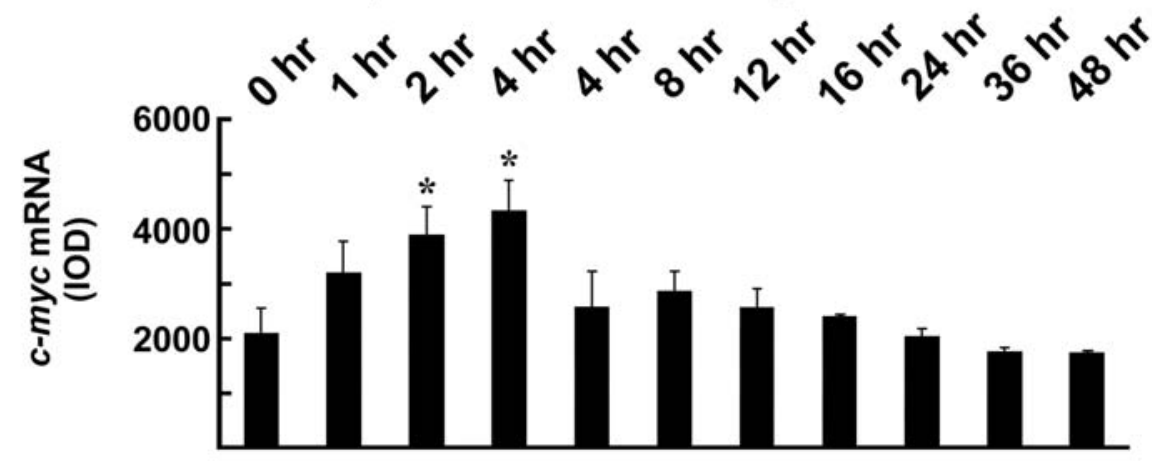

Figure 17. Expression of $c$-fos, $c$-jun, and c-myc in HPT cells acutely exposed to $\mathrm{Cd}^{+2}$. HPT cells were exposed to $53.4: \mathrm{M} \mathrm{Cd}^{+2}$ for 4 hours followed by recovery in normal growth medium. Cells were harvested for RNA at the indicated time points. (A) Expression of $c$-fos mRNA assessed by RT-PCR with gene specific primers. Shown are the IODs at 25 cycles of PCR. (B) Expression of $c$-jun mRNA assessed at 25 cycles of PCR. (C) Expression of c-myc assessed at 23 cycles of PCR. In all cases, expression is normalized to GAPDH. Statistically significant increase over control. * $(p<0.01)$. 
A
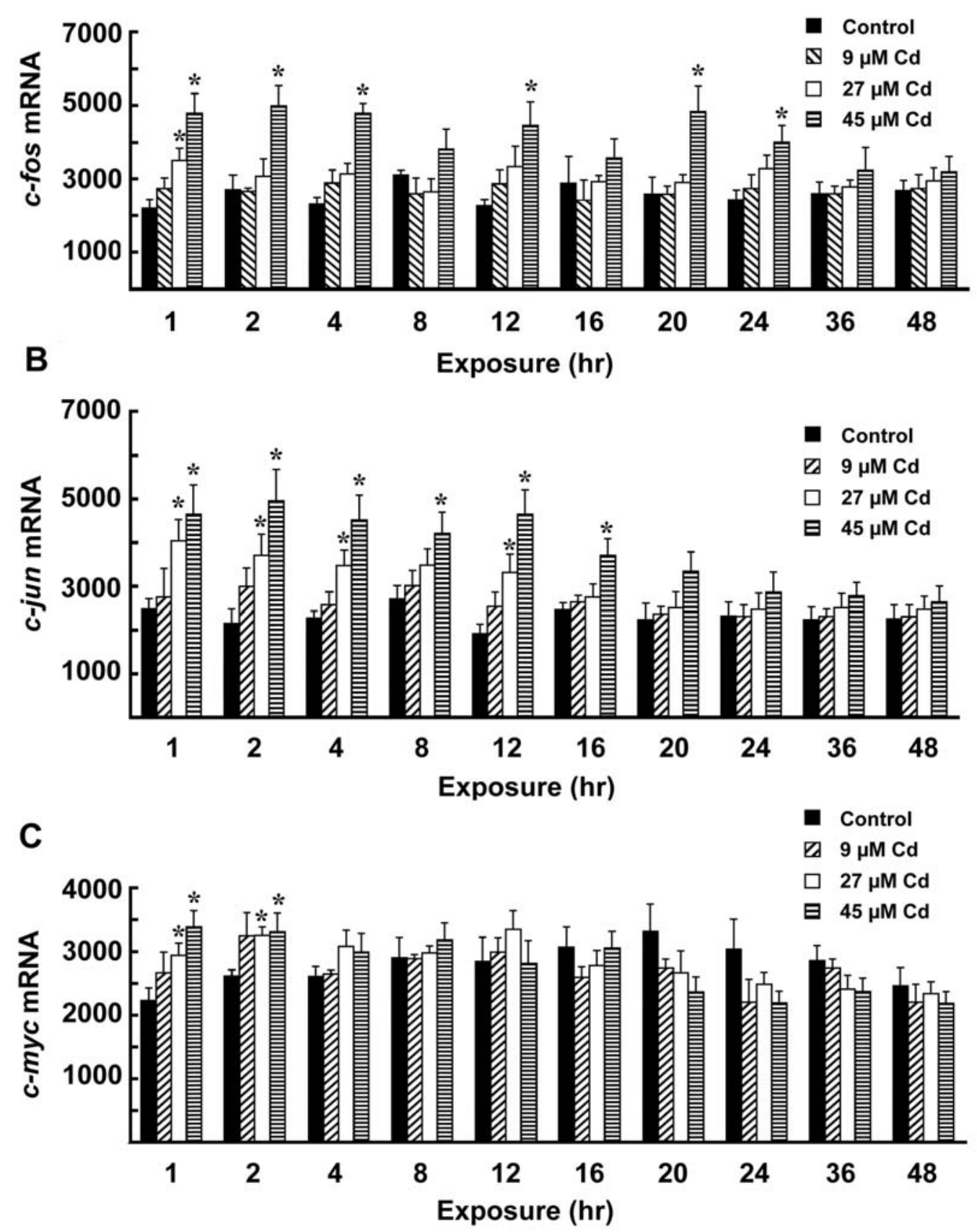

Figure 18. Expression of $c$-fos, $c$-jun, and c-myc in HPT cells exposed to $\mathrm{Cd}^{+2}$ for 48 hours. HPT cells were exposed to three levels of $\operatorname{Cd}^{+2}(9,27,45: M)$ for up to 48 hours and harvested at the indicated time points. (A) Expression of $c$-fos reported as IOD of the DNA PCR product bands at 25 cycles. (B) Expression of $c-j u n$ assessed at 23 cycles of PCR. (C) Expression of c-myc assessed at 23 cycles of PCR. In all cases, expression is normalized to GAPDH. Statistically significant increase over control. ${ }^{*}(p<0.01)$. 
18B). The intermediate exposure resulted in a modest increase in $c-j u n$ mRNA within 1 hour of exposure and a return to the control value by 16 hours of exposure. For c-myc, exposure to 27 and $45: \mathrm{M} \mathrm{Cd}^{+2}$ induced only about 1.5 -fold increase in mRNA within 1 hour and the level remained elevated for only 2 hours before returning to control values (Figure $18 \mathrm{C}$ ). $\mathrm{Cd}^{+2}$ exposure to 16 days showed that once all three mRNAs had returned to control values within 48 hours, they remained for an additional 14 days in the continuous $\mathrm{Cd}^{+2}$ exposure (Figure 19A-C).

Expression of MT-3, c-fos, c-jun and c-myc mRNA in confluent HK-2 cells exposed to $\mathrm{Cd}^{+2}$. Acute and extended time courses identical to those used for the HPT cells, were used to determine the expression of MT-3, c-fos, $c-j u n$ and c-myc mRNA in HK-2 cells exposed to $\mathrm{Cd}^{+2}$. The only difference was in the concentration of $\mathrm{Cd}^{+2}$ used in the 16 day time course which was reduced to 0.9 , 2.2 and $4.5: M$ due to the differences of sensitivity to toxicity between the cell lines (14). It was demonstrated that no MT-3 mRNA or protein could be detected from control (Figure 12, lane 9) or $\mathrm{Cd}^{+2}$-treated HK-2 cells (data not shown).

In contrast to the defference in MT-3 mRNA expression between the HPT and HK-2 cells, the expression of $c-f o s, c-j u n$ and $c-m y c$ mRNA was very similar between the two cell lines. In the acute $\mathrm{Cd}^{+2}$ exposure and recovery, there was an increase in the expression of $c$-fos, $c$-jun and c-myc mRNA in the HK-2 cells within 1 or 2 hours of exposure returning to control values after $\mathrm{Cd}^{+2}$ removal 

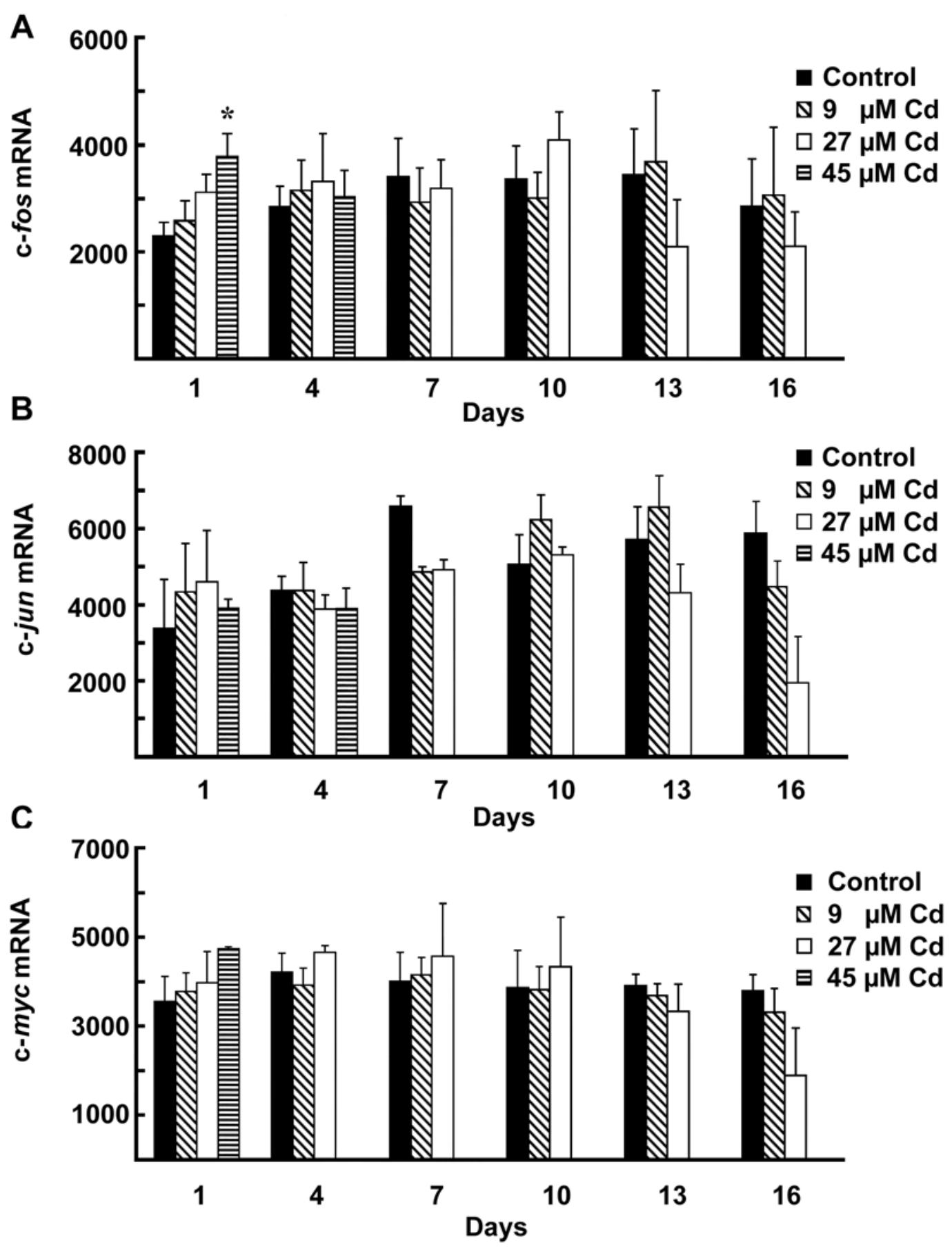

Figure 19. Expression of $c$-fos, $c$-jun, and $c-m y c$ in extended $\mathrm{Cd}^{+2}$ exposure of HPT cells. HPT cells were exposed to three levels of $\mathrm{Cd}^{+2}(9,27$, and $45: M)$ for up to 16 days and harvested at the indicated time points. (A) Expression of $c$-fos. The IOD from 28 cycles of PCR are shown. (B) Expression of $c-j u n$ assessed at 23 cycles of PCR. (C) Expression of c-myc assessed at 23 cycles. In all cases, expression is normalized to GAPDH. Statistically significant increase over control. * $(p<0.01)$. 
A

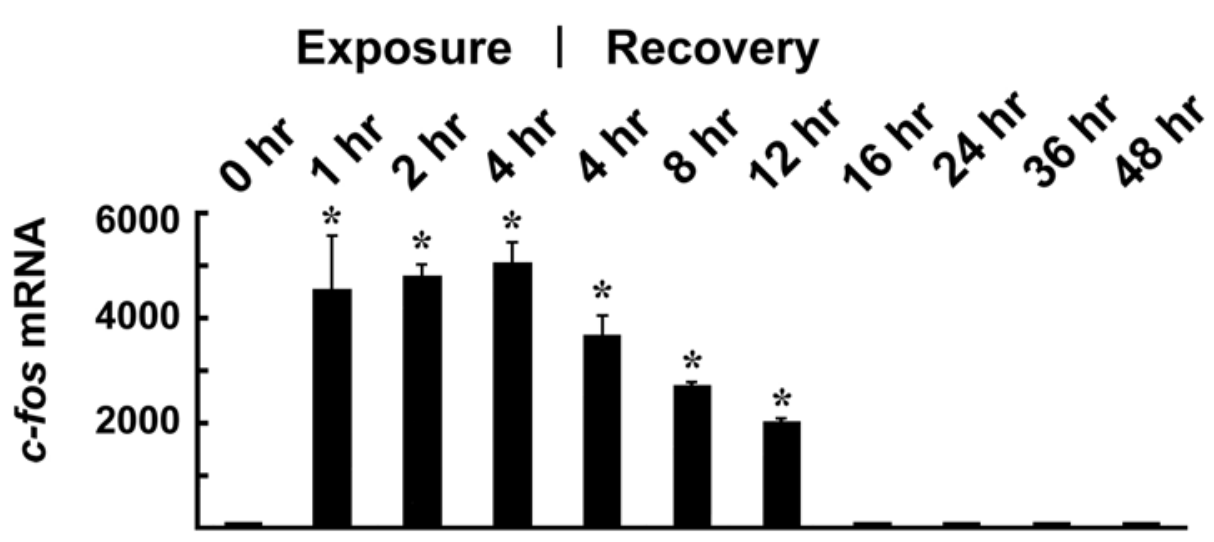

B

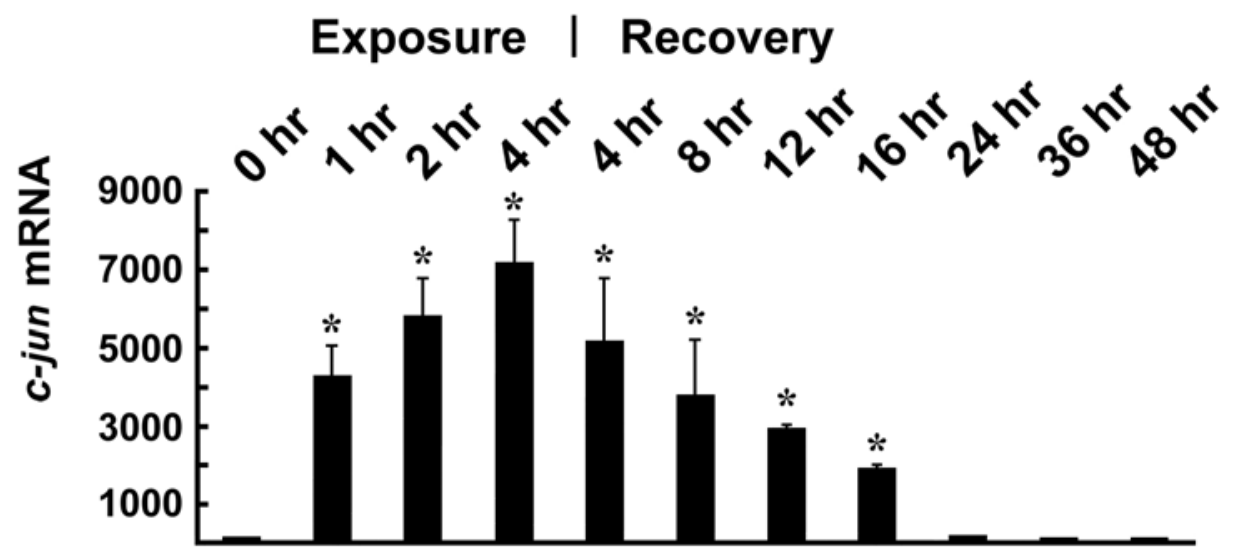

C

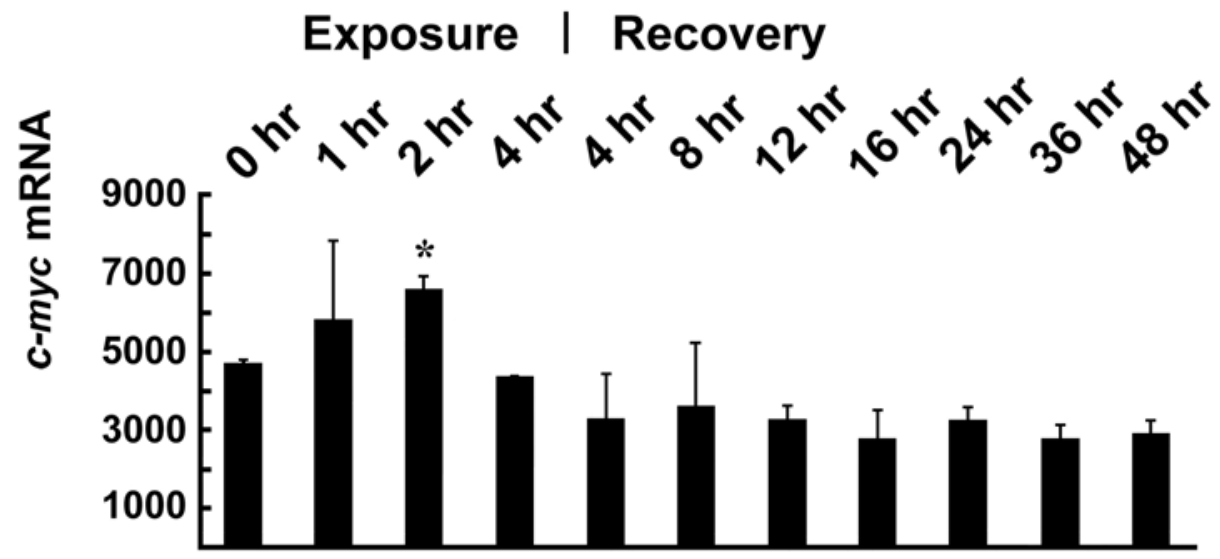

Figure 20. Expression of $c$-fos, $c$-jun, and $c-m y c$ in HK-2 cells acutely exposed to $\mathrm{Cd}^{+2}$. Cells were exposed to $53.4: \mathrm{M} \mathrm{Cd}^{+2}$ for 4 hours followed by recovery in normal growth medium. (A) Expression of $c$-fos reported as IOD of the DNA PCR product band at 23 cycles. (B) Expression of $c-j u n$ assessed at 23 cycles of PCR. (C) Expression of $c-m y c$ assessed at 23 cycles. In all cases, expression is normalized to GAPDH. Statistically significant increase over control. ${ }^{*}(p<0.01)$. 


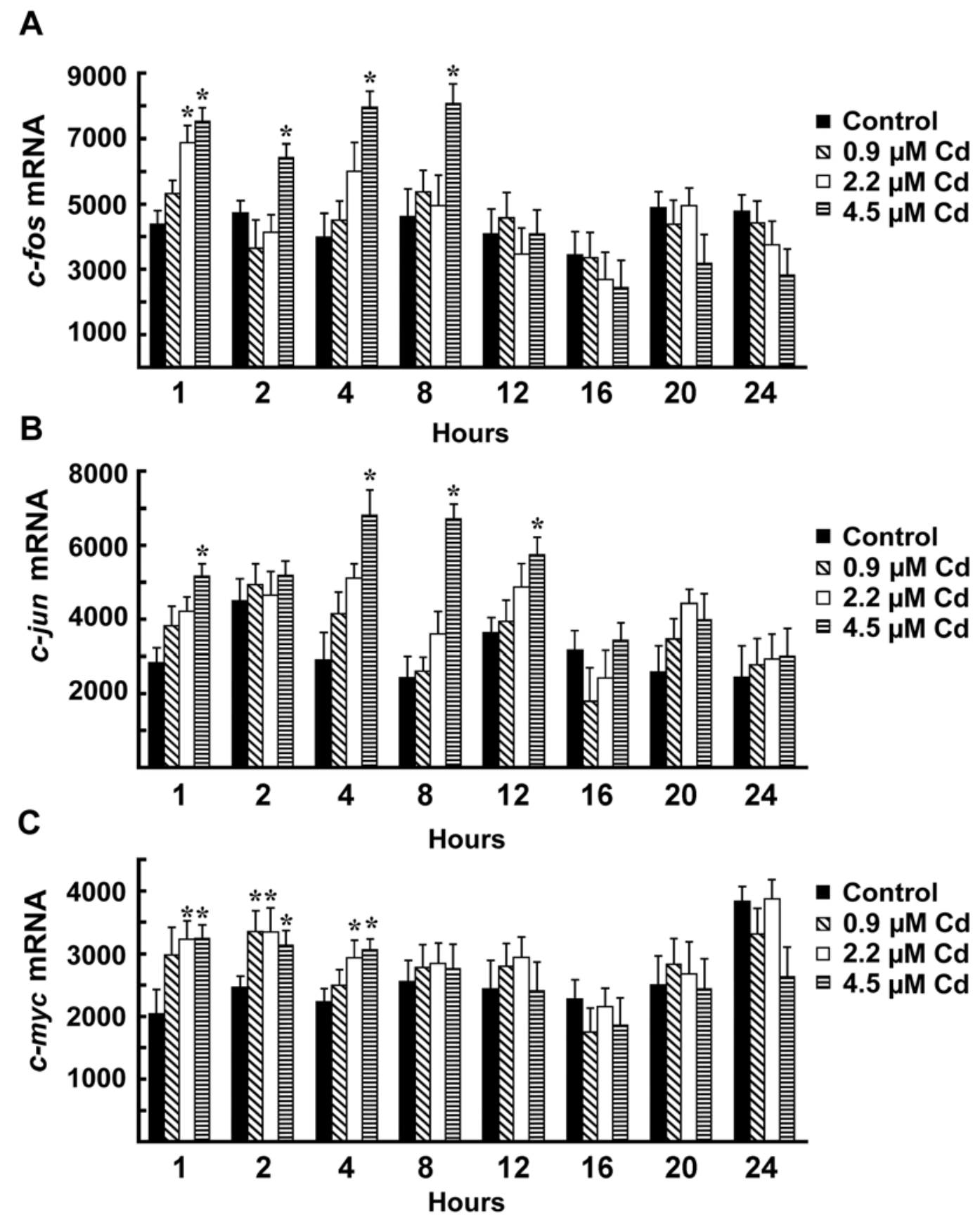

Figure 21. Expression of c-fos, c-jun, and c-myc in HK-2 cells exposed to $\mathrm{Cd}^{+2}$. Cells were exposed to $\mathrm{Cd}^{+2}(0.9,2.2$, and $4.5: \mathrm{M})$ for up to 24 hours and harvested at the indicated time points. (A) Expression of $c$-fos assessed at 23 cycles of PCR. (B) Expression of $c$-jun assessed at 25 cycles. (C) Expression of $c-m y c$ assessed at 25 cycles of PCR. In all cases, expression is normalized to GAPDH. Statistically significant increase over control. * $(p<0.01)$. 
(Figure 20A-C). When the HK-2 cells were exposed continuously to $0.9,2.2$, and 4.5: $\mathrm{M} \mathrm{Cd}^{+2}$ for 24 hours, three mRNA levels were all increased early in the time course, and returned to control values by 16 to 24 hours (Figure 21), all of which was the similar pattern as HPT cells exhibited. Like that found for the HPT cells, $c$-fos, $c$-jun and c-myc mRNA remained at control levels for an additional 15 days

in the continuous presence of both lethal and sub-lethal concentrations of $\mathrm{Cd}^{+2}$ (data not shown).

\section{DISCUSSION}

The goal of the study was to expand on our recent observations that MT-3 mRNA and protein are expressed in the human kidney and cultured human proximal tubule cells $(15,16)$. While the previous studies had shown that total RNA isolated from fresh human kidney tissue contained MT-3 mRNA and that MT-3 protein could be immunolocalized in the proximal and other tubules of tissue sections, it had not been shown that MT-3 mRNA was present in the proximal tubule or the relative level of expression. To accomplish this analysis, the proximal tubules were removed from surrounding tissue using laser-assisted microdissection, total RNA was isolated from the microdissected proximal tubules and MT-3 and \$-actin mRNA were determined using RT-PCR. This analysis demonstrated that not only was MT-3 mRNA present in the proximal tubule, but that it was a very abundant transcript. This conclusion was based on the finding that the relative expression of MT-3 was much greater than the \$-actin housekeeping gene. Thus, these results confirm the presence of MT-3 mRNA in 
the proximal tubules and also suggest that MT-3 may have an even higher level of expression in other tubule cell types of the human nephron.

The finding that MT-3 is expressed in the human kidney impacts on the initial observation that MT-3 was reported to be a brain-specific metallothionein (4). It is possible that a new pattern of MT-3 expression was gained in the human as a result of evolutionary change. The gene organization and regulation of MT are very different between human and rodent models. In the mouse, the organization of the MT gene is not complex. The genes encoding the MT-1 and MT-2 isoforms are both single copy genes, are located approximately $6 \mathrm{~kb}$ apart on mouse chromosome 8 , are coordinately regulated, and the proteins are thought to be functionally equivalent $(17,18)$. The MT-3 and MT-4 isoforms are also single copy genes and are closely linked to, but not coordinately regulated with the MT-1 and MT-2 genes on mouse chromosome $8(4,19,20)$. In the human, a gene duplication event took place, in the time scale between mouse and man, that greatly increased the complexity of the organization of the human MT genes $(20,21)$. This duplication event was mediated at the level of DNA, and not that of RNA, as evidenced by the fact the duplicated genes have intact 5' promoter, regulatory regions and 3' UTRs. As a result, the human MT locus consists of a family of genes located at $16 q 13$ consisting of 10 functional (MT-1A, MT-1B, MT-1E, MT-1F, MT-1G, MT-1H, MT-1X, MT-2A, MT-3, MT-4) and 6 nonfunctional MT isoforms (MT-1C, MT-1D, MT-1I, MT-1J, MT-1K, MT-1L). That the gene duplication event in the human was of practical significance is suggested by the fact that the human MT-1 and MT-2 genes are not coordinately regulated and 
have been shown to exhibit unique expression profiles and examples of inducerspecific and tissue-specific $(22,23,24,25,26,27,28,29)$, and developmentalspecific (30) regulation have been demonstrated. The human MT-3 and MT-4 genes in the human are within $85 \mathrm{~kb}$ of the other MT genes on human chromosome $16(4,19)$. Although there is only limited information currently available, it can be hypothesized that the tissue distribution pattern of MT-3 gene expression is different between mouse and human due to regulatory differences arising from the gene duplication event that occurred in the human MT gene locus and MT-3 in human acquires a new function in a specific tissue(s). It was reported that baby hamster kidney (BHK) cells expressing MT-1 or MT-3 act differently to zinc deficiency (31). In zinc deficiency, MT-1 did not compete with essential zinc-dependent proteins and was degraded, whereas MT-3 competed for zinc, therby reducing cell proliferation and aggravating zinc deficiency. It shows a possibility that the function of MT-3 might be different from that of MT-1.

The present study also confirmed that exposure of the HPT cells to $\mathrm{Cd}^{+2}$ induced a transient increase in MT-3 mRNA and extended the induction to include a subsequent transient increase in the level of the MT-3 protein. The current finding that MT-3 mRNA and protein are induced by $\mathrm{Cd}^{+2}$, coupled with the previous study showing induction of MT-3 mRNA by $\mathrm{Zn}^{+2}$ (1), indicates that the MT-3 gene in the human proximal tubule is metal responsive. This is an important observation since it is in contrast to studies in the mouse which show that the level of MT-3 mRNA in the brain was unaffected by both acute and chronic exposure of the animal to $\mathrm{Cd}^{+2}, \mathrm{Zn}^{+2}$, dexamethasone and 
lipopolysaccaride at concentrations that result in modest elevations of MT-1 mRNA (4). It was concluded that the rodent MT-3 gene was not regulated by these known strong inducers of the MT-1 and MT-2 isoform genes. There are two possible explanations for this discrepancy in metal-regulated MT-3 gene expression between the human HPT cells and the organs of the mouse. The simplest explanation is that rapid and transient elevation of MT-3 mRNA and protein that occurs when the HPT cells are exposed to $\mathrm{Cd}^{+2}$ would be easily missed in an animal model study. Whereas, a rapid and transient induction is very easy to model and detect in a cell culture based system, the same induction would be very difficult to detect in a whole animal study unless the experimental design was specifically planned to look for such an alteration. The second explanation would be that there is a difference in the responsiveness of the MT-3 gene by metals between the two species. The possibility for a species divergence in MT-3 regulation is increased by the finding that MT-3 has appreciable basal expression in the epithelial cells of the human renal system but not in the corresponding renal cells of the mouse $(2,4)$. Regardless of explanation, this study demonstrates that MT-3 expression is transiently increased in HPT cells exposed to lethal and sub-lethal concentrations of $\mathrm{Cd}^{+2}$.

The silencing elements in the promoter are that they may induce a conformational change causing an inhibitory effect on protein-protein interaction. It was found that a CTG repeat, one of the silencing elements, in the MT-3 promoter is not present in the human MT-3 gene (4), that only 4 repeats are present in the rat gene (12), and that the number of the CTG repeat is variable in 
mice (13). It implies that MT-3 in HPT is not negatively regulated by CTG repeat, providing a possibility that MT-3 is transiently induced by $\mathrm{Cd}^{+2}$. In addition, epigenetic modification, such as DNA methylation, can negatively regulate gene expression. Therefore, it would be valuable to search for any methylations in the MT-3 promoter of HPT cells.

The transient increase in MT-3 mRNA and protein that occurred following exposure of the HPT cells to $\mathrm{Cd}^{+2}$ is unique compared to that of the MT-1 and MT-2 isoforms. From the literature $(8,13)$ and studies on the HPT cells $(14,32)$, $\mathrm{Cd}^{+2}$ exposure classically results in a large, sustained elevation in levels of the MT-1 and MT-2 proteins so long as the cells remain exposed to the metal. Specifically, when the HPT cells were exposed to $\mathrm{Cd}^{+2}$, MT-1 and MT-2 protein accumulation increased at both lethal and sublethal concentrations of $\mathrm{Cd}^{+2}$ for 16 days or until cell death $(14,32)$. In contrast, under identical conditions of exposure, MT-3 accumulation in HPT cells initially increased, but returned to control values $48 \mathrm{hrs}$ into the time course despite the continued presence of lethal and sublethal concentrations of $\mathrm{Cd}^{+2}$. This pattern of MT-3 expression in the HPT cells was similar to that seen previously for the hsp 27 , hsp 60, and hsp 70 heat shock proteins when the HPT cells were exposed similarly to $\mathrm{Cd}^{+2}(9,10$, 11). The expression patterns of MT-3 and the hsps were also identical in that they all remained at control values in the continued presence of both lethal and sublethal concentrations of $\mathrm{Cd}^{+2}$ for 16 days or until cell death. However, there was one aspect of MT-3 expression in the classical chemical stress protocol that was not shared with the heat shock proteins. When the HPT cells were exposed 
to $53.4 \mu \mathrm{M} \mathrm{Cd}^{+2}$ for $4 \mathrm{hrs}$ followed by a recovery period, the hsps demonstrated the classical increase in both hsp mRNA and protein that extended well into the recovery period. In contrast, under identical conditions of exposure to $\mathrm{Cd}^{+2}$, while MT-3 mRNA was increased similar to the hsps, there was no increase in the level of the MT-3 protein. This would suggest that the continued presence of $\mathrm{Cd}^{+2}$ is required for the transient expression of the MT-3 protein.

The fact that MT-3 has been found to be overexpressed in several human cancers suggested the possibility that the growth regulatory activity of MT-3 could extend beyond the neural system. In human prostate cancer, MT-3 overexpression has been shown in a subset of tumors, with degree of expression correlating to tumors with higher Gleason scores $(2,3)$. In bladder cancer, MT-3 overexpression was found in all human bladder cancers and the degree of overexpression correlated to tumor grade (33). In human breast cancer, MT-3 overexpression has been shown in a subset of tumors and expression correlated with disease outcome (34). These observations linking MT-3 expression to the loss of growth control, suggested that MT-3 might have an expression pattern similar to the early response genes. To test this possibility, the expression of $c$ fos, $c-j u n$ and c-myc mRNA was determined in parallel to that of MT-3 during the time courses of exposure of the HPT cells to $\mathrm{Cd}^{+2}$. It has been shown previously that the immortal LLC-PK 1 cell line derived from porcine kidney has increased expression of the c-fos, $c$-jun and c-myc mRNAs following acute exposure to $\mathrm{Cd}^{+2}$ (35). It was demonstrated that the expression of the three early reponse genes was very similar to that of MT-3 mRNA. That is, there was a rapid, 
transient increase in the expression of $c$-fos, $c$-jun and c-myc mRNA that returned to control values in the continued presence of $\mathrm{Cd}^{+2}$. It was reported that changes of early response gene expression in normal human prostate epithelial cells appears to be the initiation of apoptosis (36). Also, it was suggested that apoptotic processes may be involved in $\mathrm{Cd}^{+2}$-induced nephrotoxicity (37). Although, the mechanism of $\mathrm{Cd}^{+2}$-induced apoptosis is not clear yet, it was shown that proto-oncogenes c-myc and c-jun participate in the $\mathrm{Cd}^{+2}$-induced apoptosis (38). Thus, it can be hypothesized from this study that MT-3 is transiently induced by $\mathrm{Cd}^{+2}$ to activate an apoptotic signaling pathway in HPT cells, thereby eliminating damaged cells. While a circumstantial observation, when coupled with the alterations of MT-3 expression in three human cancers, it argues that some consideration should be given to the possibility that the growth regulatory activity of MT-3 noted in the neural system may also be active in nonneural tissues that express MT-3.

Lastly, the HK-2 cell line was assessed in parallel studies for the $\mathrm{Cd}^{+2}$ induced expression of MT-3. The HK-2 cells are immortal, available from the ATCC and easy to maintain in the laboratory. This is in contrast to the HPT cells which are mortal and not as widely available due to the high cost of purchase or the need to have access to human tissue resources. The HK-2 cells were shown to have no $\mathrm{Cd}^{+2}$-induced expression of MT-3, but they did retain the basal and $\mathrm{Cd}^{+2}$-induced pattern of early response gene expression found in the HPT cells. Thus, while the HK-2 cells will not serve as a model to study the effects of metal exposure of MT-3 expression, they may provide a valuable model system to 
study the effects that stable transfection and subsequent overexpression of MT-3 has on an MT-3 negative cell line that retains differentiated features of the proximal tubule, which will be discussed in the next chapter.

\section{REFERENCES}

1. Hoey, J. G., Garrett, S. H., Sens, M. A., Todd, J. H., and Sens, D. A. Expression of MT-3 mRNA in human kidney, proximal tubule cell cultures, and renal cell carcinoma. Toxicol. Lett. 92:149-160, 1997.

2. Garrett, S. H., Sens, M. A., Todd, J. H., Somji, S., and Sens, D. A. Expression of MT-3 protein in the human kidney. Toxicol. Lett. 105:207-214, 1999.

3. Garrett, S. H., Sens, M. A., Shukla, D., Nestor, S., Somji, S., Todd, J. H., and Sens, D. A. Metallothionein isoform 3 expression in the human prostate and cancer-derived cell lines. The Prostate 41:196-202, 1999.

4. Palmiter, R. D., Findley, S. D., Whitmore, T. E., and Durnam, D. M. MT-III, a brain-specific member of the metallothionein gene family. Proc. Natl. Acad. Sci. USA 89:6333-6337, 1992.

5. Bernard, A., Roels, H., Hubermont, G., Buchet, J. P., Masson, P. L., and Lauwerys, R., Characterization of the proteinuria in Cd exposed workers. Int. Arch. Occup. Environ. Health 38:19-30, 1976.

6. Gonich, H. C., Indraprasit, S., Rosen, V. J., Neustein, H., Van de Velde, R., and Raghavan, S. R. V. Effect of cadmium on renal tubular function, the ATPNa-ATPase transport system and renal tubular ultrastructure. Mineral Electrol. Metab. 3:21-35, 1980. 
7. Bosco, E., Porta, N., and Diezi, J. Renal handling of cadmium: A study by tubular microinjections. Arch. Toxicol. 7:371-373, 1986.

8. Andrews, G. K. Regulation of metallothionein gene expression by oxidative stress and metal ions. Biochem. Pharmacol. 59:95-104, 2000.

9. Somji, S., Sens, D. A., Garrett, S. H., Sens, M. A., and Todd, J. H. Heat shock protein 27 expression by human proximal tubule cells exposed to lethal and sublethal concentrations of $\mathrm{CdCl}_{2}$. Environ. Health Persect. 107:545-552, 1999.

10. Somji, S., Todd, J. H., Sens, M. A., Garrett, S. H., and Sens, D. A. Expression of the constitutive and inducible forms of heat shock protein 70 in human proximal tubule cells exposed to heat, sodium arsenite and $\mathrm{CdCl}_{2}$. Environ Health Perspect. 107:887-894, 1999.

11.Somji, S., Todd, J. H., Sens, M. A., Garrett, S. H., and Sens, D. A. Expression of heat shock protein 60 in human proximal tubule cells exposed to heat, sodium arsenite, and $\mathrm{CdCl}_{2}$. Toxicol. Lett. 115:127-136, 2000.

12. Chapman, G. A., Kay, J., and Kille, P. Structural and functional analysis of the rat metallothionein III genomic locus. Biochim. Biophys. Acta 1445:321-329, 1999.

13. Hamer, D. H. Metallothionein. Ann. Rev. Biochem. 55:913-951, 1986.

14. Garrett, S. H., Somji, S., Todd, J. H., and Sens, D. A. Exposure of human proximal tubule cells to $\mathrm{Cd}^{+2}, \mathrm{Zn}^{+2}$, and $\mathrm{Cu}^{+2}$ induces metallothionein protein accumulation, but not metallothionein isoform 2 mRNA. Environ. Health Perspect. 106:587-596, 1998. 
15. Hoey, J. G., Garrett, S. H., Sens, M. A., Todd, J. H., Sens, D. A. Expression of MT-3 mRNA in human kidney, proximal tubule cell cultures, and renal cell carcinoma. Toxicol. Lett. 92:149-160, 1997.

16. Garrett, S. H., Sens, M. A., Todd, J. H., Somji, S., and Sens, D. A. Expression of MT-3 protein in the human kidney. Toxicol. Lett. 105:207-214, 1999.

17. Kagi, J. H. R., and Hunziker, P. Mammalian metallothionein. Biol. Trace Element Res. 21:111-118, 1989.

18. Searle, P. F., Davison, B. L., Stuart, G. W., Wilkie, T. M., Norstedt, G., and Palmiter, R. D. Regulation linkage and sequence of mouse metallothionein I and II genes. Mol. Cell Biol. 4:1221-1230, 1984.

19. Quaife, C. J., Findley, S. D., Erickson, J. C., Froelick, G. J., Kelly, E. J., Zambrowicz, B. P., and Palmiter, R. D. Induction of a new metallothionein isoform (MT-IV) occurs during differentiation of stratified squamous epithelia. Biochemistry. 33:7250-7259, 1994.

20.West, A. K., Stallings, R., Hildebrand, C. E., Chiu, R., Karin, M., and Richards, R. Human metallothionein genes: structure of the functional locus at 16q13. Genomics 8:513-518, 1990.

21.Stennard, F. A., Holloway, A. F., Hamilton, J., and West AK. Characterization of six additional human metallothionein genes. Biochim. Biophys. Acta 1218:357-365, 1994.

22. Garrett, S. H., Sens, M. A., Shukla, D., Flores, L., Somji, S., Todd, J. H., and Sens, D. A. Metallothionein isoform 1 and 2 gene expression in the human 
prostate: Down-regulation of MT-1X in advance prostate cancer. The Prostate 43:125-135, 2000.

23. Garrett, S. H., Somji, S., Todd, J. H., and Sens, D. A. Exposure of human proximal tubule cells to $\mathrm{Cd}^{+2}, \mathrm{Zn}^{+2}$, and $\mathrm{Cu}^{+2}$ induces metallothionein protein accumulation, but not metallothionein isoform 2 mRNA. Environ. Health Perspect. 106:587-596, 1998.

24. Richards. R. I., Heguy, A., and Karin, M. Structural and functional analysis of the human metallothionein-I $I_{A}$ gene: differential induction by metal ions and glucocorticoids. Cell 37:263-272, 1984.

25. Jahroudi, N., Foster, R., Price-Haughey, J., Beitel, G., and Gedamu, L. Celltype specific and differential regulation of the human metallothionein genes. J. Biol. Chem. 265:6506-6511, 1990.

26. Pauwels, M., Van Weyenbergh. J., Soumillion, A., Proost, P., and DeLey, M. Induction by zinc of specific metallthionein isoforms in human monocytes. Eur. J. Biochem. 220:105-110, 1994.

27. Soumillion, A., Van Damme, J., and DeLey, M. Cloning and specific polymerized-chain-reaction amplification of a third charge-separable human metallothionein isoform. Eur. J. Biochem. 209:999-1004, 1992.

28. Sadhu, C., and Gedamu, L. Regulation of human metallothionein (MT) genes. J. Biol. Chem. 263:2679-2684, 1988.

29. Garrett, S. H., Somji, S., Todd, J. H., Sens, M. A., and Sens, D. A. Differential expression of human metallothionein isoform I mRNAs in human proximal tubule cells exposed to metals. Environ. Health Perspect. 106:825-832, 1998. 
30.Schmidt, C. J., and Hamer, D. H. Cell specificity and an effect of ras on human metallothionein gene expression. Proc. Natl. Acad. Sci. USA 83:3346$3350,1986$.

31. Palmiter, R. D. Constitutive expression of metallothionein-III (MT-III), but not MT-1, inhibits growth when cells become zinc deficient. Toxicol. Appl. Pharmacol. 135:139-146, 1995.

32. Garrett, S. H., Somji, S., Todd, J. H., Sens, M. A., and Sens, D. A. Differential expression of human metallothionein isoform I mRNAs in human proximal tubule cells exposed to metals. Environ. Health Perspect. 106:825-832, 1998.

33. Sens, M. A., Somji, S., Lamm, D. L., Garrett, S. H., Slovinsky, F., Todd, J. H., and Sens, D. A. Metallothionein isoform 3 as a potential biomarker for human bladder cancer. Environ. Health Perspect. 108:413-418, 2000.

34. Sens, M. A., Somji, S., Garrett, S. H., and Sens, D. A. Metallothionein isoform 3 (MT-3) overexpression is associated with breast cancers having a poor prognosis. Am. J. Pathol. 159:21-26, 2001.

35. Matsuoka, M., and Call, K. M. Cadmium-induced expression of immediate early genes in LLC-PK 1 cells. Kidney Int. 48:383-389, 1995.

36. Achanzar, W. E., Achanzar, K. B., Lewis, J. G.,Webber, M. M., and Waalkes, M. P. Cadmium induces $c-m y c, p 53$, and $c$-jun expression in normal human prostate epithelial cells as a prelude to apoptosis. Toxicol. Appl. Pharmacol. 164:291-300, 2000. 
37. Ishido, M., Homma-Takeda, S., Tohyama, C., and Suzuki, T. Apoptosis in rat renal proximal tubular cells induced by cadmium. J. Toxicol. Environ. Health. 55:1-12, 1998.

38. Jin, P., and Ringertz, N. R. Cadmium induces transcription of protooncogenes c-jun and c-myc in rat L6 myoblasts. J. Biol. Chem. 265:1406114064, 1990. 


\section{METALLOTHIONEIN ISOFORM 3 AND VECTORIAL ACTIVE TRANSPORT IN HUMAN PROXIMAL TUBULES ${ }^{2}$}

2 The contents of this chapter was published in Kidney International 61:464-72, 2002. 


\section{INTRODUCTION}

It was shown that MT-3 tissue-specific gene expression is broader than previously reported, that is, in the rat, MT-3 mRNA was reportedly expressed mainly in the brain and in other organs, such as testis, prostate, ovary, stomach, and heart, but not in kidney (1). However, MT-3 mRNA was present in total RNA isolated from human kidney tissue and cultures derived from the human proximal tubule (2). Basal level of MT-3 expression and its transient inducibility by $\mathrm{Cd}^{+2}$ in HPT were confirmed in the previous chapter (Title : Transient Induction of metallothionein Isoform 3,c-fos, c-jun and c-myc in human proximal tubule cells exposed to cadmium) of this dissertation. Like other MTs, MT-3 might provide $\mathrm{Cd}^{+2}$ resistance in HPT cells, since it also has highly conserved 20 cysteines and can sequester metals (3). HPT cell cultures retain many of the structural and functional features of differentiation expected of cells derived from the proximal tubule (4) and could serve as a good model to study $\mathrm{Cd}^{+2}$-induced nephrotoxicity. These cells upon reaching confluency halt proliferation and become highly polarized due to tight junction formation and are capable of vectorial active transport as noted by dome formation (5). The immortal HK-2 cell line which is derived from cultures of HPT cells retains many features of the proximal tubules but lacks vectorial active transport (5). The goal of this chapter was to determine if MT-3 is involved in the resistance of cells to the toxic effects of the heavy metal, $\mathrm{Cd}^{+2}$, and to determine if MT-3 participates in the maintenance of proximal tubule cell function. 


\section{RESULTS}

Increased susceptibility of human proximal tubule cells to cadmium by treatment with a MT-3 antisense oligonucleotide. Transient transfection of MT-3 antisense oligonucleotide into mortal HPT cells was performed to see if down-regulation of MT-3 expression renders increased susceptibility to $\mathrm{Cd}^{+2}$ (Figure 22). Random antisense oligonucleotide, MT-2A antisense oligonucleotide, and MT-3 antisense oligonucleotide were used for the experiment (6). The sequences of three antisense oligonucleotides are listed in Materials and Methods. The sub-lethal concentration $(3: \mathrm{g} / \mathrm{ml})$ of $\mathrm{Cd}^{+2}$ was exposed to the HPT cells as a control. The same concentration of $\mathrm{Cd}^{+2}$ was exposed to the three groups of HPT cells following three different antisense oligonucleotides were incubated with lipofectin in each group. There was about 10-30 \% reduction of MT-3 mRNA level in control, and MT-2A antisense oligonucleotide groups by the treatment of $\mathrm{Cd}^{+2}$ (Figure 22A). However, MT-3 mRNA was reduced by $50 \%$ in MT-3 antisense oligonucleotide group by $\mathrm{Cd}^{+2}$. Also, MT-3 protein level decreased about $40 \%$ in MT-3 antisense oligonucleotide group by $\mathrm{Cd}^{+2}$ treatment (Figure 22B). In contrast, no MT-3 protein level decreased in other three groups. Cell numbers per field were reduced by $25 \%$ in control, $30 \%$ in random antisense oligonucleotide, and $30 \%$ in MT-2A antisense oligonucleotide group by the treatment of $\mathrm{Cd}^{+2}$ (Figure 22C). However, the cell numbers were decreased by $60 \%$ in MT-3 antisense oligonucleotide group exposed to $\mathrm{Cd}^{+2}$. This result suggested that down-regulation of MT-3 increased the susceptibility of HPT cells to cadmium exposure, and it implied that MT-3 


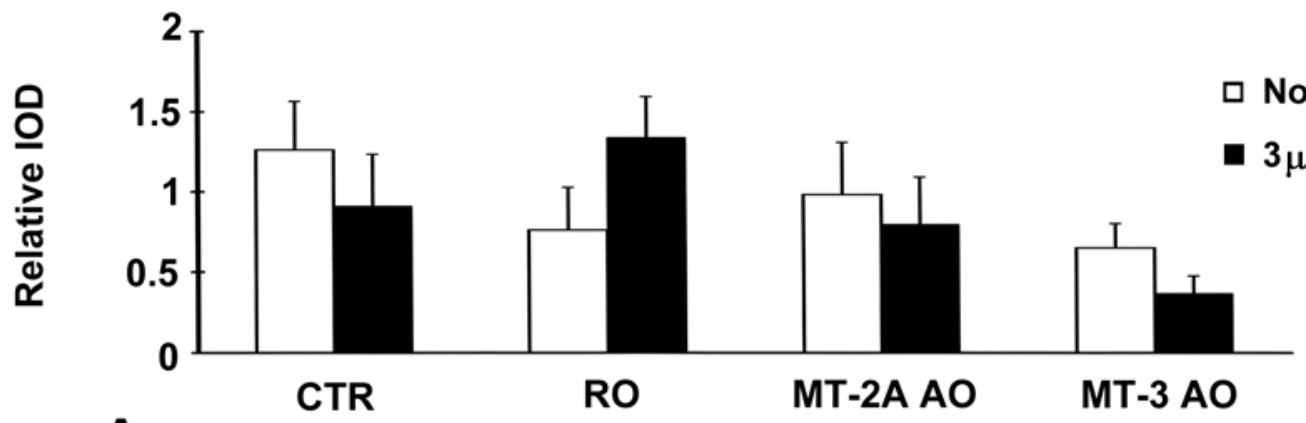

A
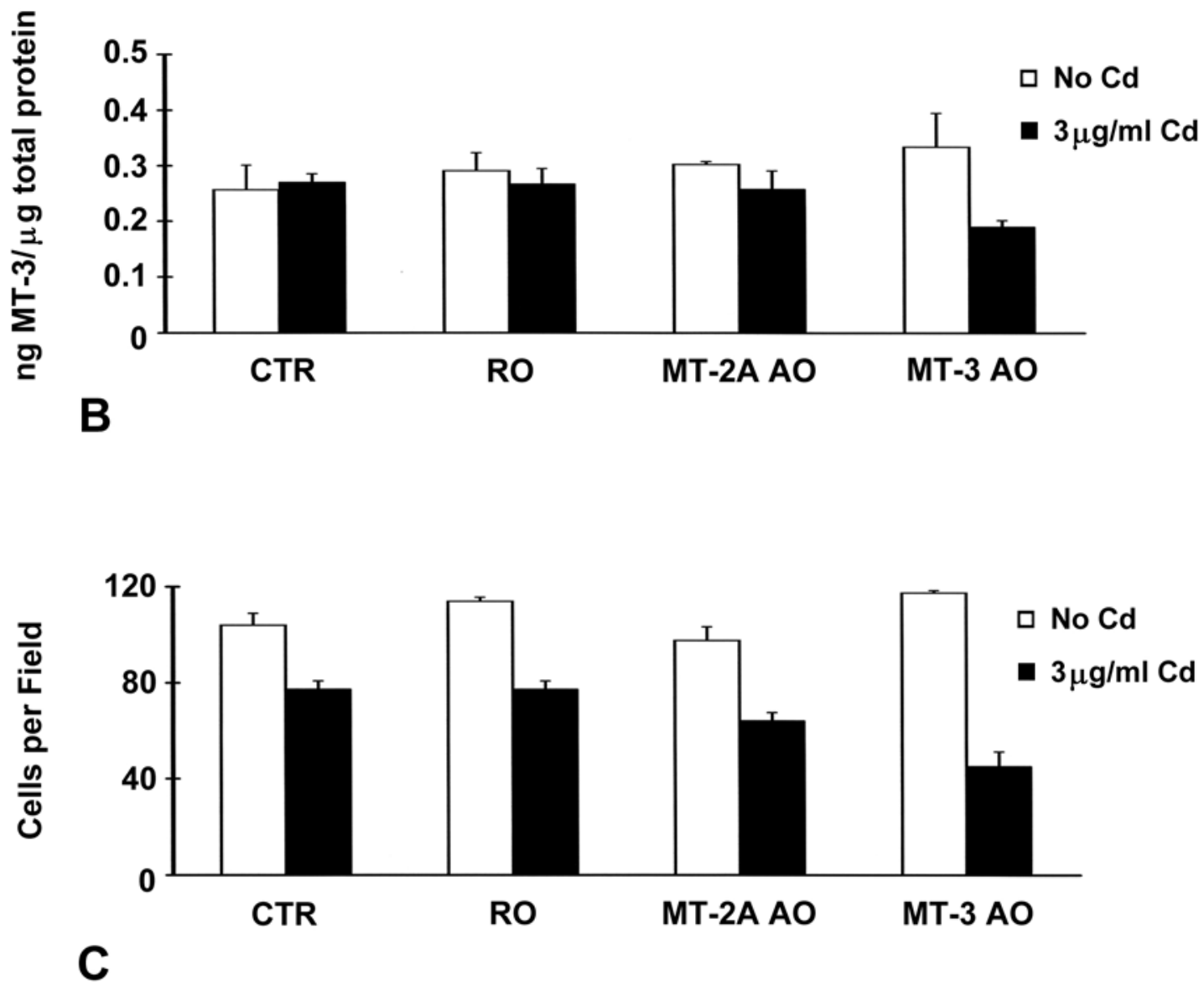

Figure 22. Inhibition of HPT cell growth by MT-3 antisense oligonucleotide. No antisense oligonucleotide (CTR), random antisense oligonucleotide (RO), MT-2A antisense oligonucleotide (MT-2A AO), or MT-3 antisense oligonucleotide (MT-3 $\mathrm{AO}$ ), was transiently transfected into HPT cells for 48 hours. Then, the cells were incubated with $3: \mathrm{g} / \mathrm{ml} \mathrm{Cd}^{+2}$ for another 24 hours and MT-3 mRNA expression (A), MT-3 protein expression (B), and cell numbers (C) were measured. 
might be involved in the protection of HPT cells against $\mathrm{Cd}^{+2}$ toxicity at least in part. In MT-2A antisense oligonucleotide group, the reduction of cell numbers by $\mathrm{Cd}^{+2}$ was not much lower than those in control or random antisense oligonucleotide group (Figure 22C). Probably, it is because MT-2A antisense oligonucleotide did not work effectively in the cells or because highly induced MT-1 isoform by $\mathrm{Cd}^{+2}$ could still protect HPT cells, even though MT-2A mRNA is down-regulated by MT-2A antisense oligonucleotide.

Expression of MT-1 and MT-2 in the immortalized human proximal tubule cell line, HK-2. Stable transfection technology is considerably valuable to study the function(s) of the gene of interest. HK-2 was chosen as a HPT cell line for MT-3 gene to be stably transfected, since basal MT-3 mRNA expression was not detected in the cell line (Figure 12, lane 9). The basal mRNA expression of other MTs in HK-2 was investigated (Figure 23A, B, C). HK-2 exhibited the expression of three major mRNAs of MT-1E, MT-1X, MT-2A, but not those of MT-1A, MT-1G, and MT-4 (data not shown). The patterns and the levels of MT-1 and MT-2 isoform mRNA expression in HK-2 are similar to those in HPT cells. Therefore, these results showed that only MT-3 mRNA was not expressed in HK2 cells compared to HPT cells.

MT-3 mRNA and protein expression in HK-2 cell line stably transfected with MT-3 gene. Since the HK-2 cells were shown to have no expression of MT-3 mRNA or protein, this cell line was used as a recipient for stable transfection with a vector designed to overexpress the MT-3 gene. The coding sequence of the MT-3 gene was obtained from HPT cell RNA by RT- 


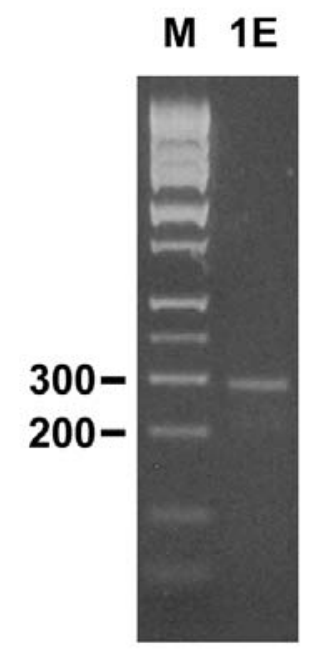

A

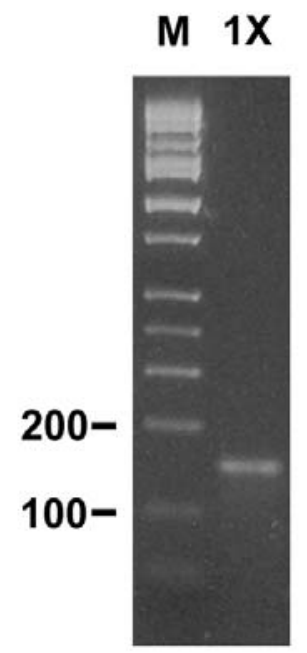

B

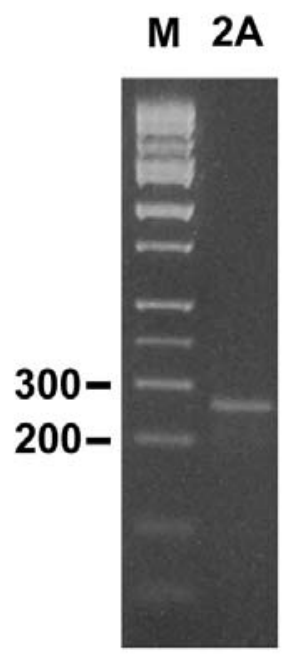

C

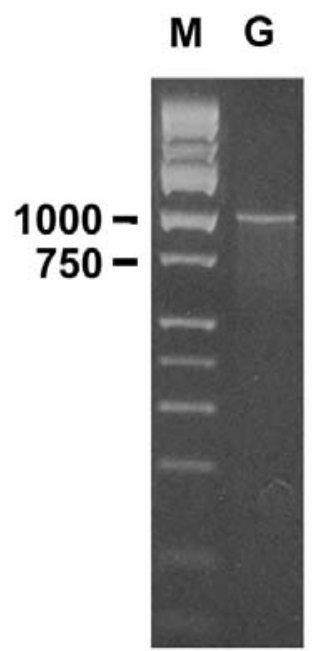

D

Figure 23. RT-PCR analysis of MT expression in HK-2 cell line. The band of RTPCR product of MT-1E (A), MT-1X (B), MT-2A (C), or GAPDH (D) is on the right lane and $M$ representing a molecular weight marker is on the left lane in each gel. 
PCR, blunt end ligated into the EcoR $\vee$ site of pcDNA3.1/Hygro(+), and linearized by Fsp I prior to transfection of the HK-2 cells. The HK-2 cells were transfected with the MT-3 plasmid construct in the sense orientation or with the vector alone using the Effectene protocol followed by selection in hygromycin B-containing growth medium. Five clones containing the MT-3 sequence, 2 clones containing the vector only sequence, and 1 clone of the wild type HK-2 cells were selected for further characterization. MT-3 mRNAs were not detected in the HK-2 cells transfected with pcDNA 3.1/Hygro (+) alone (Figure 24; V1 and V2, respectively). However, mRNAs of MT-3 were detected in the HK-2 cells transfected with MT-3 in pcDNA 3.1/Hygro (+) (Figure 24; C1-C5). Likewise, in contrast to the HK-2 cells parental and transfected with pcDNA 3.1/Hygro (+) alone (Figure 24; P, V1 and V2), all five MT-3 clone cells expressed MT-3 proteins at the levels of 2 to 10 ng/: g protein (Figure 24; C1-C5).

MT-3 in HK-2 cells in restoration of vectorial active transport. An examination of a routine light level morphology of the cells was performed as they proliferated and attained confluency. The light level morphology of the HK-2 cells possessing the MT-3 construct were similar during growth, but markedly altered at confluency as noted by the formulation of domes (arrow), structures not present in either the vector-only control cells or in the HK-2 parent cells (Figure 25A, B, C). The presence of domes are a routine feature of the HPT cells (Figure 25D) (7). The formation of domes are a hallmark of cultured renal epithelial cells that retain the in situ property of vectorial active transport (7).

Each of the five MT-3 transfected clones were noted to form domes, while 


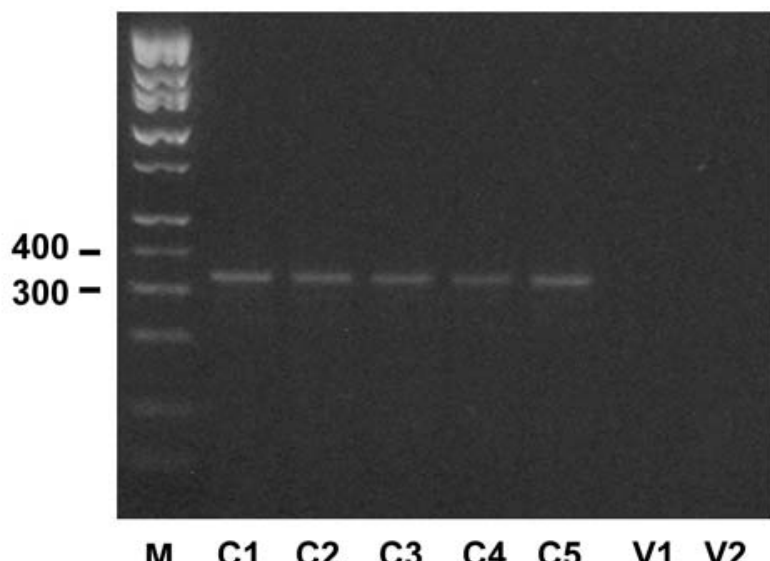

A

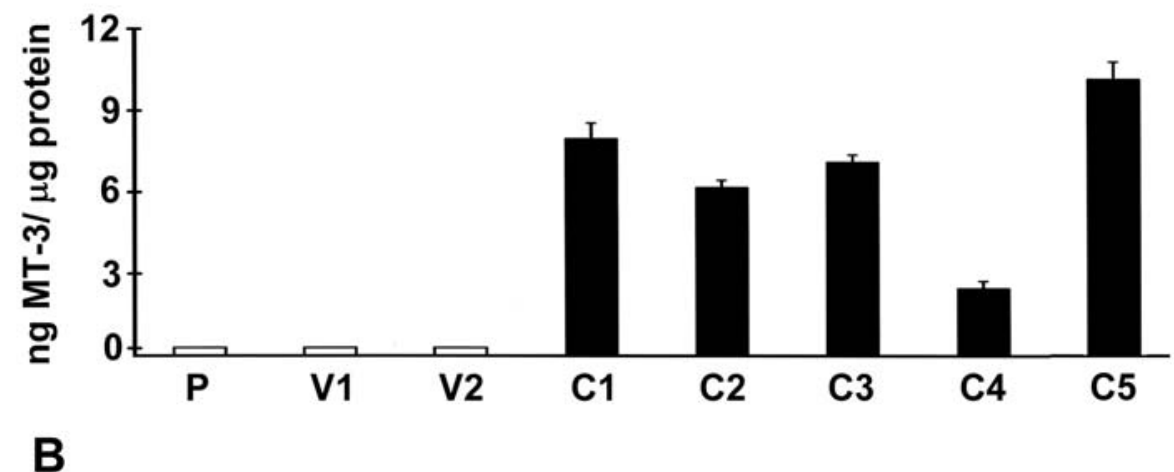

Figure 24. Overexpression of MT-3 mRNA and protein in HK-2 cell line. MT-3 in pcDNA 3.1/Hyg (+) was transfected into HK-2 cell line which has no endogenous expression of MT-3. The transfected cells were selected with $30: \mathrm{g} / \mathrm{ml}$ of hygromycin and 5 hygromycin-resistant clone cells were grown in 6-well plate to obtain the total mRNA and proteins. RT-PCR analysis (A) and Immuno-dot blot analysis (B) of HK-3 parental, vector alone and MT-3 clone cells were given. 

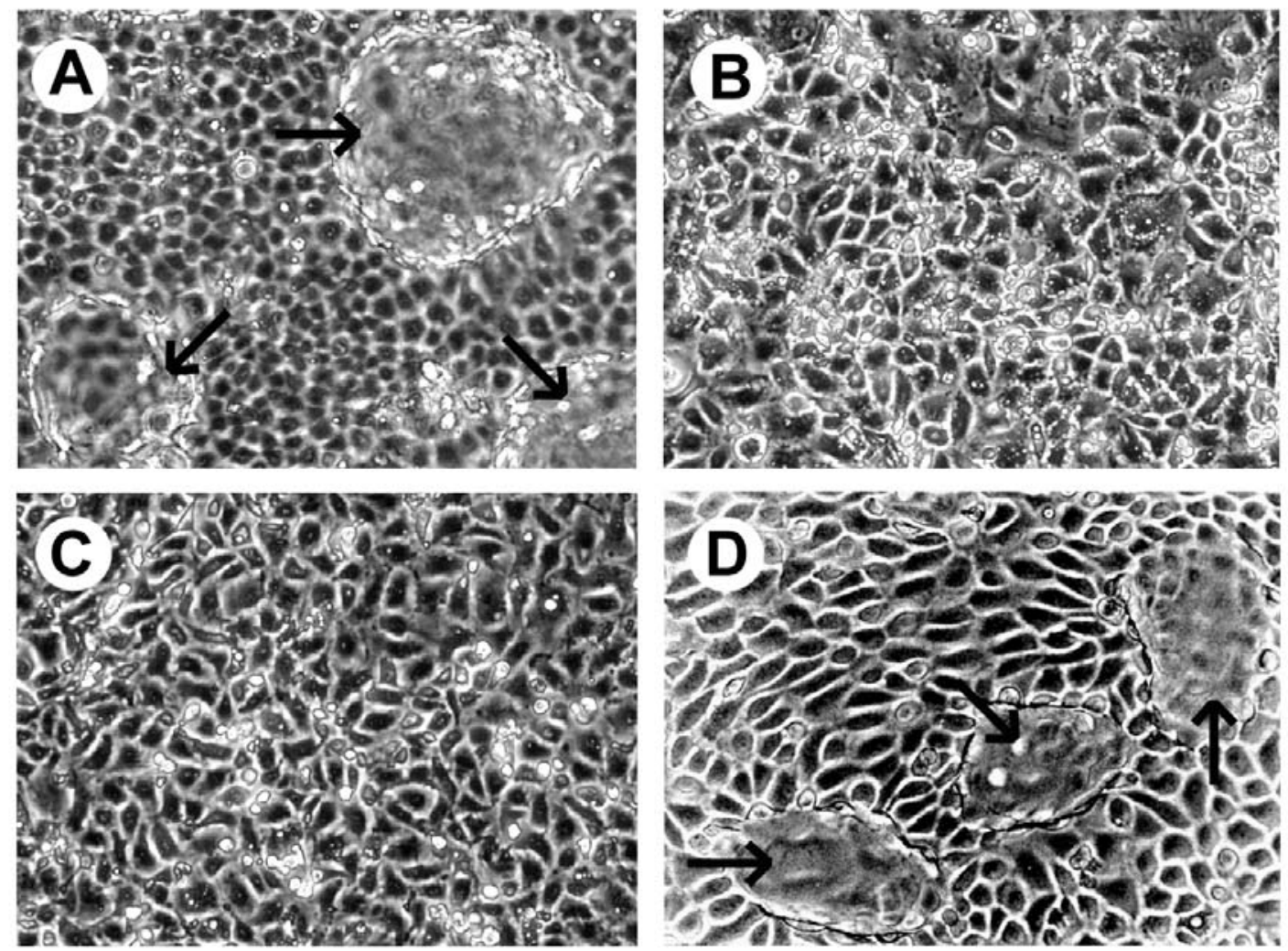

Figure 25. Light level morphology of HK-2 cells with and without MT-3 expression. (A) HK-2 stably transfected with MT-3 (Clone \#2). Arrows designate the presence of domes. (B) HK-2 stably transfected with the vector without MT-3. (C) HK-2 parental cells. (D) Normal HPT cells exhibiting domes (arrows). Cells were passaged at a 1:2 raio and allowed to attain confluency for two weeks. Original magnification $\times 40$. 

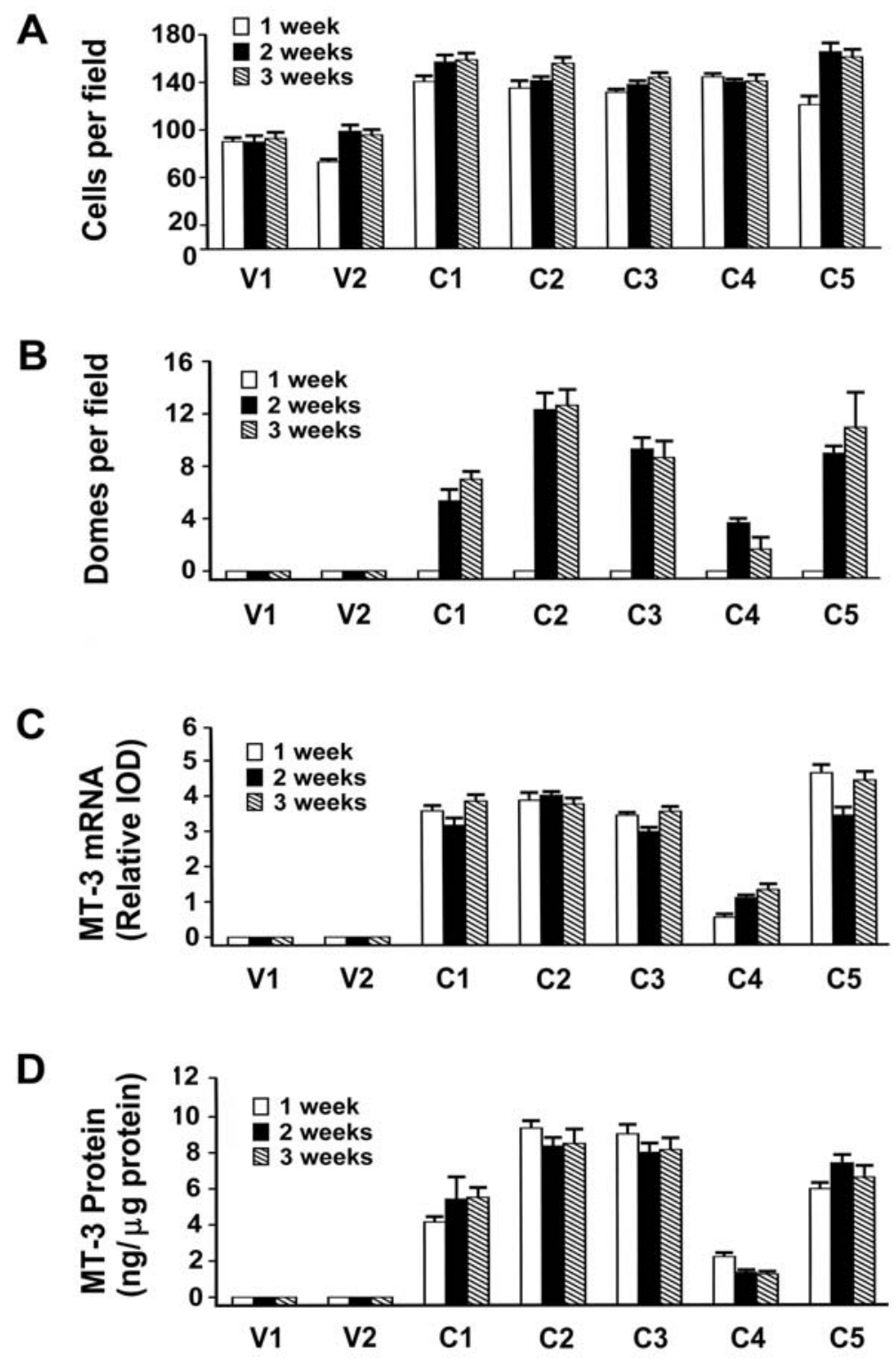

Figure 26. MT-3 expression and dome formation in MT-3 transfected clones. Each MT-3 expressing clone (designated C1 through C5) and two vector only transfected clones (V1 and V2) were passaged 1:2 in $25 \mathrm{~cm}^{2}-\mathrm{T}$ flasks. Pictures were taken and the cells were harvested for protein and RNA at 1, 2, and 3 weeks. (A) Average cell count. (B) Number of domes per 4x objective field (Mean \pm SE of three $4 x$ objective fields). (C) MT-3 mRNA expression assessed by RTPCR. Shown are the IOD of the MT-3 PCR product band at 30 cycles normalized to that of g3pdh at 30 cycles of PCR. (D) MT-3 protein expression. Protein extracts were prepared from cells at 1,2, and 3 weeks, and assessed for levels of MT-3 protein by immuno-dot blot. 
neither the vector-only control cells or parental cells were noted to form any domes. The growth rates of the MT-3 expressing HK-2 clones, the vector-only controls and the parental cells were all similar and the cells attained confluency within 4 days following a 1:2 subculture (data not shown). Upon reaching confluency, the MT-3 expressing HK-2 cells did appear to become more tightly packed compared to control cells (Figure 26A), resulting in higher cell numbers per field. The extent of dome formation, MT-3 mRNA, and MT-3 protein expression were determined $7,14,21$ days after subculture at a 1:2 split ratio for each of the 5 clones of HK-2 cells stably transfected with the MT-3 coding sequence and the 2 clones of vector-only control cells. Each of the 7 cultures were shown to have attained confluency 7 days following cell culture and to remain contact inhibited for 14 additional days (Figure 26A). The 5 clones of HK2 cells transfected with the MT-3 coding sequence were all shown to reach a higher saturation density at confluent (cells per unit area) than the HK-2 cells transfected with the vector-only control (Figure 26A). This difference in confluency was quite marked between the two sets of cultures, being increased by approximately $50 \%$ for the MT-3 transfected cells. There was no dome formation in any of the 7 cultures one week following subculture (Figure 26B). At 14 and 21 days, all 5 clones of HK-2 cells containing the MT-3 coding sequence had formed domes, while neither of the 2 vector-only controls had domes (Figure 26B). The number of domes per unit area was similar among 4 of the $5 \mathrm{HK}-2$ clones containing the MT-3 sequence, while one clone (\#4) had a reduced level of dome formation. Visual observation of the respective cultures suggested the 
higher cell density of the MT-3 transfected cells to be due to a tighter packing of the cells within the monolayer compared to control cells, rather than a multilayering of the MT-3 transfected cells. The expression of MT-3 mRNA was elevated approximately $3-4$ fold when compared relative to that of the g3pdh housekeeping gene and expression was not influenced by the time the cells were maintained at confluency (Figure 26C). In general, the expression of MT-3 protein followed that of MT-3 mRNA in the 5 clones of HK-2 cells stably transfected with MT-3 (Figure 26D). One of the clones (\#4) possessing reduced expressions of MT-3 mRNA (approximately equal to g3pdh expression) and MT3 protein, was also noted to produce less dome formation than the other MT-3 expression clones did. The MT-3 protein expression in the 5 HK-2 clones was increased 5 to 15 fold over that present in the HPT cells under basal conditions of growth. The 2 vector-only control clones demonstrated no expression of MT-3 protein at any of the 3 time points.

\section{DISCUSSION}

An opportunity to begin to determine the functional significance of MT-3 expression in the proximal tubule was provided by the finding that the immortalized human proximal tubule cell line, HK-2, did not express detectable MT-3 mRNA or protein. This was a fortuitous finding since the HK-2 cell line is one of the few immortal human cell lines that have been isolated from primary proximal tubule cultures derived from adult kidneys (8). It retains many of these features associated with the proximal tubule and mortal cultures of HPT cells. 
This includes positivity for alkaline phosphatase, (-glutamyltranspeptidase, leucine aminopeptidase, acid phosphatase, cytokeratin, " ${ }_{3} \$_{1}$ integrin, and fibronectin; and negativity for Factor VIII-related antigen, 6.19 antigen and CALLA endopeptidase. The HK-2 cells also displays sodium-dependent glucose transport and adenylate cyclase responsiveness to parathyroid hormone but not to antidiuretic hormone. A feature not present in the parent HK-2 cell line was the ability to retain the in situ property of vectorial active transport as evidenced by dome formation by confluent cell monolayers. The three requirements of dome formation are the functional plasma membrane polarization, the formation of occluding junctions (tight junctions), and the vectorial transepithelial active ion transport (9). It is presently unknown which of these processed are deficient in the cultures of the HK-2 cells. However, when the HK-2 cell line was stably transfected with a vector containing the MT-3 coding sequence under the control of the CMV promoter, dome formation was induced in the HK-2 cell line. This finding provides the first indication that MT-3 could be of functional significance in the proximal tubule as it relates to vectorial active transport.

The induction of dome formation in the HK-2 cell line by stable transfection with MT-3 was reproducible, with dome formation being present in the cultures derived from 5 independent clones, all of which were chosen for analysis before measurement of MT-3 expression. In 4 of 5 cultures, the extent of doming was very similar as were the corresponding levels of MT-3 mRNA and protein. In the culture from the one clone that exhibited a reduced incidence of dome formation, there was a corresponding reduced expression of MT-3 mRNA and protein. 
However, the fact that this culture, which expressed lower levels of MT-3, still formed domes is important because the level of both doming and expression of MT-3 protein are closer to that noted to occur in the HPT cell cultures. No dome formation was noted in HK-2 cells transfected with the vector containing no MT-3 coding sequence. The induction of dome formation appears to be specific for MT3 , since the HK-2 cells do express basal levels of mRNA for the MT-2A, MT-1X, and MT-1E genes at levels similar to those found in the HPT cells and in identity with those found in total RNA from fresh kidney tissue (unpublished observation). The only other obvious effect that MT-3 expression had on the HK-2 cells was that they appeared to pack more tightly into the monolayer than the parent cell line. MT-3 overexpressing HK-2 clone cells inducing dome formation and packing tightly into the monolayer and HPT cells expressing basal MT-3 were more resistant to $\mathrm{Cd}^{+2}$ than HK-2 cells expressing no MT-3, and MT-3 antisense oligonucleotide could enhance sensitivity to $\mathrm{Cd}^{+2}$ in HPT cells. These results demonstrated that MT-3 contributed HPT cells to resist against $\mathrm{Cd}^{+2}$-induced nephrotoxicity by forming domes and packing tightly, thereby possibly reducing $\mathrm{Cd}^{+2}$ uptake and/or increasing $\mathrm{Cd}^{+2}$ efflux, as well as by metal-chelating. It is not known either $\mathrm{Na}^{+}-\mathrm{K}^{+}$ATPase is functional or MT-3 restores $\mathrm{Na}^{+}-\mathrm{K}^{+}$ATPase activity in HK-2 cell line. However, at least, MT-3 retrieved tight junction, because morphologically all 5 MT-3 transfected HK-2 cells packed more tightly in a wellordered form.

A study on rat mammary cell line demonstrated that there are three gene products involved in dome formation (10). Epithelial $\mathrm{Na}^{+}$channel appears to be 
directly reponsible for dome formation and a gene of 133 negatively regulates $\mathrm{Na}^{+}$channel expression, removing domes. The continuous expression of another independent gene of rat8 is necessary for domes. Of course, further studies will be required to determine the mechanism underlying the induction of dome formation by expression of the MT-3 gene in HK-2 cells.

In conclusion, this study provides the first evidence that MT-3 expression is involved in the transport function of a human renal cell line retaining properties of the proximal tubule.

\section{REFERENCES}

1. Moffatt, P., and Seguin, C. Expression of the gene encoding metallothionein-3 in organs of the reproductive system. DNA Cell Biol. 17:501-510, 1998.

2. Hoey, J. G., Garrett, S. H., Sens, M. A., Todd, J. H., Sens, D. A. Expression of MT-3 mRNA in human kidney, proximal tubule cell cultures, and renal cell carcinoma. Toxicol. Lett. 92:149-160, 1997.

3. Sewell, A. K., Jensen, L. T., Erickson, J. C., Palmiter, R. D., and Winge, D. R. Bioactivity of metallothionein-3 correlates with its novel \$ domain sequnce rather than metal binding properties. Biochemistry 34:4740-4747, 1995.

4. Garrett, S. H., Sens, M. A., Shukla, D., Flores, L., Somji, S., Todd, J. H., and Sens, D. A. Metallothionein isoform 1 and 2 gene expression in the human prostate: Down-regulation of MT-1X in advance prostate cancer. The Prostate 43:125-135, 2000. 
5. Garrett, S. H., Sens, M. A., Shukla, D., Nestor, S., Somji, S., Todd, J. H., Sens, D. A. Metallothionein isoform 3 expression in the human prostate and cancer-derived cell lines. The Prostate 41:196-202, 1999.

6. Garay, M., Gaarde, W., Monia, B. P., Nero, P., and Cioffi, C. L. Inhibition of hypoxia/reoxygenation-induced apoptosis by an antisense oligonucleotide targeted to JNK1 in human kidney cells. Biochem. Pharmacol. 59:1033-1043, 2000.

7. Sens, D. A., Detrisac, C. J., Sens, M. A., Rossi, M. R., Wenger, S. L., and Todd, J. H. Tissue culture of human renal epithelial cells using a defined serum-free growth formulation. Exper. Nephrol. 7:344-352, 1999.

8. Ryan, M. J., Johnson, G., Kirk, J., Fuerstenberg, S. M., Zager, R. A., and Torok-Storb, B. HK-2: An immortalized proximal tubule epithelial cell line from normal adult human kidney. Kidney Int. 45:48-57, 1994.

9. Lever, J. E. Inducers of dome formation in epithelial cell cultures including agents that cause differentiation, Chapter 1. In Tissue Culture of Epithelial Cells, Edited by Taub M, New York, Plenum Press, pp3-22, 1985.

10.Zucchi, I., Montagna, C., Susani, L., Montesano, R., Affer, M., Zanotti, S., Redolfi, E., Vezzoni, P., and Dulbecco, R. Genetic dissection of dome formation in a mammary cell line: Identification of two genes with opposing action. Proc. Natl. Acad. Sci. USA 96:13766-13770, 1999. 


\section{APPENDIX A}

CELL CULTURE REAGENTS AND SOLUTIONS 


\section{Dulbecco's Modified Eagle Medium (DMEM)}

Low glucose DMEM (Gibco-BRL, Rockvillle, MD., Cat No. 31600-75) with Lglutamine and sodium pyruvate $(100 \mathrm{mg} / \mathrm{ml})$ but without sodium bicarbonate, was stored in powdered form at $4^{\circ} \mathrm{C}$. To prepare 5 liters of DMEM, $49.9 \mathrm{~g}$ of medium powder was dissolved in $4,945 \mathrm{ml}$ of filtered water in a 6 liter flask with constant stirring. To this solution, $50 \mathrm{ml}$ of penicillin streptomycin (Gibco-BRL, Cat No.15140-122), $5 \mathrm{ml}$ of Fungizone ${ }^{\mathrm{TM}}$ (Gibco-BRL, Cat No.15295-017) and $18.5 \mathrm{~g}$ of sodium bicarbonate (Gibco-BRL, Cat No.11810-033) were added. The solution was stirred for 30 minutes at room temperature and then sterile filtered under a fume hood using a $0.2: \mathrm{m}$ Acrocap ${ }^{\mathrm{TM}}$ filter (Gelman Laboratory, Ann Arbor, MI, USA. Cat. No. PN4480). Filtered medium was stored in $500 \mathrm{ml}$ aliquots at $4^{\circ} \mathrm{C}$ for up to six months.

\section{Ham's F-12 Nutrient Mixture}

Ham's F-12 Nutrient Mixture (Gibco-BRL, Cat No. 21700-109) with L-glutamine, but without sodium bicarbonate, was stored in powdered form at $4^{\circ} \mathrm{C}$. To prepare 5 liters of F-12 Medium, $53.1 \mathrm{~g}$ of medium powder was dissolved in $4,945 \mathrm{ml}$ of filtered water in a 6 liter flask with constant stirring. To this solution $50 \mathrm{ml}$ of penicillin streptomycin, $5 \mathrm{ml}$ of Fungizone ${ }^{\mathrm{TM}}$ and $5.88 \mathrm{~g}$ of sodium bicarbonate were added. The solution was stirred for 30 minutes at room temperature and then sterile filtered under a fume hood using a $0.2:$ Acrocap $^{\top \mathrm{M}}$ filter. Filtered medium was stored in $500 \mathrm{ml}$ aliquots at $4^{\circ} \mathrm{C}$ for up to six months.

\section{Phosphate Buffered Saline (1x PBS)}


To make 5 liters of $1 \mathrm{x}$ PBS, $42.5 \mathrm{~g}$ of $\mathrm{NaCl}$ (Sigma, Cat No. S-9888) was combined with $0.6 \mathrm{~g} \mathrm{Na}_{2} \mathrm{HPO}_{4}$ (Fisher Scientific, Fair Lawn, NJ, USA. Cat No. S374) and $0.12 \mathrm{~g} \mathrm{NaH}_{2} \mathrm{PO}_{4}$ (Fisher Scientific, Cat No. S-369) in a total volume of 5 liters of filtered water. PBS was aliquoted into $500 \mathrm{ml}$ bottles and autoclaved. PBS was stored for up to one year at $4^{\circ} \mathrm{C}$.

\section{Serum-Free Medium Additives}

\begin{tabular}{|c|c|c|}
\hline Reagent & Vendor & Working Concentrations \\
\hline $\begin{array}{c}\text { Insulin } \\
\text { (I) }\end{array}$ & $\begin{array}{l}\text { Collaborative Biomed, } \\
\text { Bedford, MA, USA. } \\
\text { (Cat No. 40310) }\end{array}$ & $\begin{array}{c}\text { 1000x Concentration }(5 \mathrm{mg} / \mathrm{ml}) \\
\text { Reconstituted in sterile } \mathrm{H}_{2} \mathrm{O}\end{array}$ \\
\hline $\begin{array}{l}\text { Transferrin } \\
\text { (T) }\end{array}$ & $\begin{array}{l}\text { Collaborative Biomed } \\
\quad(\text { Cat No. 40204) }\end{array}$ & $\begin{array}{l}\text { 1000x Concentration }(5 \mathrm{mg} / \mathrm{ml}) \\
\text { Reconstituted in sterile } \mathrm{H}_{2} \mathrm{O}\end{array}$ \\
\hline $\begin{array}{l}\text { Selenous Acid } \\
\text { (S) }\end{array}$ & $\begin{array}{l}\text { Collaborative Biomed } \\
\quad(\text { Cat No. 40201) }\end{array}$ & $\begin{array}{l}\text { 1000x Concentration }(5: \mathrm{g} / \mathrm{ml}) \\
\text { Reconstituted in sterile } \mathrm{H}_{2} \mathrm{O}\end{array}$ \\
\hline $\begin{array}{c}\text { 3,3',5 } \text {-Triiodo- } \\
\text { L-Thyronine } \\
\text { sodium salt } \\
\left(\mathrm{T}_{3}\right) \\
\end{array}$ & $\begin{array}{c}\text { Sigma, Inc. } \\
\text { (Cat No. T5516) }\end{array}$ & $\begin{array}{c}1000 \times \text { Concentration }(4 \mathrm{pg} / \mathrm{ml}) \\
\text { Reconstituted in DMEM and } 0.01 \mathrm{~N} \\
\mathrm{NaOH}(20: \mathrm{g} / \mathrm{ml}) \text {. Final dilution (4 } \\
\mathrm{pg} / \mathrm{ml}) \text { was made with sterile PBS. }\end{array}$ \\
\hline $\begin{array}{l}\text { Hydrocortizone } \\
\text { (HC) }\end{array}$ & $\begin{array}{c}\text { Sigma, Inc. } \\
\text { (Cat No. H0135) }\end{array}$ & $\begin{array}{l}\text { 1000x Concentration }(36.4: \mathrm{g} / \mathrm{ml}) \\
\text { Reconstituted in sterile PBS }\end{array}$ \\
\hline $\begin{array}{c}\text { Epidermal } \\
\text { Growth Factor } \\
\text { (EGF) }\end{array}$ & $\begin{array}{l}\text { Gibco-BRL. } \\
\text { (Cat No. 13247-051) }\end{array}$ & $\begin{array}{l}\text { 100x Concentration }(1 \mathrm{mg} / \mathrm{ml}) \\
\text { Reconstituted in sterile PBS }\end{array}$ \\
\hline L-Glutamine & $\begin{array}{c}\text { Gibco-BRL. } \\
\text { (Cat No. 25030-081) }\end{array}$ & $\begin{array}{c}100 \times \text { Concentration }(29.2 \mathrm{mg} / \mathrm{ml} \text { in } \\
0.85 \% \mathrm{NaCl}) \text { Direct aliquot }\end{array}$ \\
\hline
\end{tabular}

\section{Nitex Cloth}

Circles of Nitex cloth with $11.0-\mathrm{cm}$ filter paper were cut as a template. Plastic funnel and Nitex filters (3-4 needed/isolation) in a small amount of water were autoclaved. It was used as a paper filter to remove tissue fragments from decanted mixture of tissue and HBSS.stored for up to one year at $4^{\circ} \mathrm{C}$. 


\section{APPENDIX B}

PCR PRIMERS AND PARAMETERS 
PCR PRIMERS

\begin{tabular}{|c|c|c|c|c|c|}
\hline \multirow{2}{*}{ Gene } & \multirow{2}{*}{ endor } & \multicolumn{2}{|r|}{ UP Primer } & \multicolumn{2}{|r|}{ LOW Primer } \\
\hline & & $\overline{\text { on }}$ & Seque & Cron & Sequence \\
\hline GAPDH & & $\begin{array}{l}.075 \\
: M\end{array}$ & 5'TGAAGC & $\begin{array}{c}0.075 \\
: M\end{array}$ & $\begin{array}{l}\text { 5'CATG } \\
\text { GAGGT }\end{array}$ \\
\hline & $\begin{array}{l}\text { en } \\
0 \\
\end{array}$ & $0.15: M$ & $\begin{array}{r}5^{\prime} C A \\
G G C A \\
\end{array}$ & $\begin{array}{l}0.15 \\
: M \\
\end{array}$ & AGCA \\
\hline & $\begin{array}{l}\text { Sen } \\
03\end{array}$ & $15: M$ & $\begin{array}{c}\text { 5'TGTTTTGGGA } \\
\text { GGGGGTTGTGC3' }\end{array}$ & $\begin{array}{l}0.15 \\
: M \\
\end{array}$ & $\begin{array}{l}\text { 5'AAC } \\
\text { CCAC }\end{array}$ \\
\hline $\begin{array}{l}\text { hsp 70A } \\
\text { (360 bp) }\end{array}$ & $\begin{array}{l}\text { en } \\
6 \\
6\end{array}$ & $0.15: M$ & $\begin{array}{r}\text { 5'TG } \\
\text { CCAG }\end{array}$ & $\begin{array}{l}0.15 \\
: M\end{array}$ & $\begin{array}{l}5 \text { 'GG } \\
\text { CCGT }\end{array}$ \\
\hline $\begin{array}{l}\text { hsp 70B } \\
\text { (234 bp) }\end{array}$ & $\begin{array}{l}\text { Sen } \\
07\end{array}$ & $15: M$ & $\begin{array}{r}\text { 5'CTCCAGCA } \\
\text { GACAAGAAC }\end{array}$ & $\begin{array}{c}0.15 \\
: M\end{array}$ & $\begin{array}{r}\text { 5'ACGGTGT } \\
\text { GGGGGTTCA }\end{array}$ \\
\hline & 88 & $0.15: M$ & $\begin{array}{l}\text { 5'TTG } \\
\text { GGAT }\end{array}$ & $\begin{array}{l}0.15 \\
: M\end{array}$ & $\begin{array}{l}\text { 5'AG } \\
\text { GTG1 }\end{array}$ \\
\hline $\begin{array}{c}\text { hsc } 70 \\
\text { (342 bp) } \\
\end{array}$ & 5 & $: M$ & $\begin{array}{l}\text { 5'TG } \\
\text { TTCC }\end{array}$ & $\begin{array}{l}0.15 \\
: M\end{array}$ & $\begin{array}{l}\text { 5'GCC } \\
\text { TTCAC }\end{array}$ \\
\hline $\begin{array}{c}\text { MT1A } \\
\text { (219 bp) } \\
\end{array}$ & $3 R L$ & $M$ & $\mathrm{ACC}$ & $1: M$ & $\begin{array}{r}\text { 5'ATA } \\
\text { GCAGC } \\
\end{array}$ \\
\hline $\begin{array}{c}\text { MT1B } \\
\text { (287 bp) } \\
\end{array}$ & $\mathrm{RL}$ & u & $\begin{array}{r}\text { 5'GCT } \\
\text { GCT } \\
\end{array}$ & & $\begin{array}{r}\text { 5'AGA } \\
\text { GGTCA } \\
\end{array}$ \\
\hline $\bar{M}$ & bco-BRL & $1 \cdot M$ & $\begin{array}{l}\text { 5'GC } \\
\mathrm{CTC} \\
\end{array}$ & $.1: M$ & $\begin{array}{l}5{ }^{\prime} C A \\
A G G \\
\end{array}$ \\
\hline $\begin{array}{c}\text { MT1F } \\
\text { (232 bp) }\end{array}$ & $\mathrm{RL}$ & $.1: M$ & $\begin{array}{r}5^{\prime} A G T \\
\text { CGG }\end{array}$ & $\mathrm{M}$ & $\begin{array}{c}\text { 5'ACATCTC } \\
\text { GAGAAAGG } \\
3^{\prime}\end{array}$ \\
\hline $\begin{array}{r}\mathrm{M}^{-} \\
(30 \\
\end{array}$ & BRL & IVI & $\mathrm{G}$ & $M$ & $\begin{array}{l}5^{\prime} \mathrm{AG} \\
\text { ATTC }\end{array}$ \\
\hline & BRL & $M$ & $\begin{array}{l}\text { 5'CCT } \\
\text { TCTCC }\end{array}$ & $1: M$ & \begin{tabular}{|l} 
5'GCAA \\
CGGAG
\end{tabular} \\
\hline $\begin{array}{c}\text { MT1X } \\
\text { (151 bp) } \\
\end{array}$ & $3 R L$ & $4.1 \mathrm{NI}$ & $\begin{array}{l}\text { 5'TCTC } \\
\text { TCGAA }\end{array}$ & $: M$ & $\begin{array}{l}\text { 5'GGGE } \\
\text { GGCA }\end{array}$ \\
\hline $\begin{array}{c}\text { MT2A } \\
\text { (259 bp) } \\
\end{array}$ & $3 R L$ & $0.1: M$ & $\begin{array}{l}\text { STCTAG } \\
\text { TCTT3' } \\
\end{array}$ & $\mathrm{M}$ & $\begin{array}{l}\text { 5'GTG } \\
\text { CGTTC }\end{array}$ \\
\hline & bco-BRL & $\begin{array}{l}0.125 \\
: M \\
\end{array}$ & $\begin{array}{r}\mathrm{CCG} \\
\mathrm{CC} 1 \\
\end{array}$ & $\begin{array}{c}0.125 \\
: \mathrm{M} \\
\end{array}$ & $\begin{array}{l}\text { 5'CAC } \\
\text { ACTTC }\end{array}$ \\
\hline $\begin{array}{c}\text { MT4 } \\
(213 \mathrm{bp})\end{array}$ & $\mathrm{RL}$ & & $\begin{array}{l}\text { TGGACCCC } \\
\text { 'GAATGTGT3' }\end{array}$ & $: \mathbb{M I}$ & $\begin{array}{r}\text { 5'GGG } \\
\text { CG }\end{array}$ \\
\hline
\end{tabular}




\begin{tabular}{|c|c|c|c|c||c|}
\hline $\begin{array}{c}c-f o s \\
(612 \mathrm{bp})\end{array}$ & Clontech & $0.4: \mathrm{M}$ & $\begin{array}{c}\text { 5'AAGGAGAATCCG } \\
\text { AAGGGAAAGGAAT } \\
\text { AAGATGGCT3' }\end{array}$ & $0.4: \mathrm{M}$ & $\begin{array}{c}\text { 5'AGACGAAGGGA } \\
\text { AGACGTGTAAGC } \\
\text { AGTGCAGCT3' }\end{array}$ \\
\hline \hline $\begin{array}{c}c-j u n \\
(409 \mathrm{bp})\end{array}$ & Clontech & $0.4: \mathrm{M}$ & $\begin{array}{c}\text { 5'GCATGAGGAAC } \\
\text { CGCATCGCTGCC } \\
\text { TCCAAGT3' }\end{array}$ & $0.4: \mathrm{M}$ & $\begin{array}{c}\text { 5'GCGACCAAGT } \\
\text { CCTTCCCACTC } \\
\text { GTGCACACT3' }\end{array}$ \\
\hline \hline $\begin{array}{c}c-m y c \\
(479 \mathrm{bp})\end{array}$ & Clontech & $0.4: \mathrm{M}$ & $\begin{array}{c}\text { 5'TACCCTCTCAAC } \\
\text { GACAGCAGCTCG } \\
\text { CCCAACTCCT3' }\end{array}$ & $0.4: \mathrm{M}$ & $\begin{array}{c}\text { 5'TCTTGACATT } \\
\text { CTCCTCGGTGT } \\
\text { CCGAGGACCT3' }\end{array}$ \\
\hline
\end{tabular}

Heat shock protein (hsp) and glyceraldehyde 3-phosphate dehydrogenase (GAPDH) primers pairs were obtained from StressGen (Victoria, British Columbia, Canada) and Clonetech (Palo Alto, CA, USA), respectively. The selection of metallothionein primer pairs for RT-PCR was described by Mididoddi et al. ((1996) Toxicol Lett. 85(1):17-27).

\section{PCR TEMPERATURES AND CYCLES}

\begin{tabular}{|c|c|c|c|}
\hline PCR Product & Denaturation & \multicolumn{2}{|c|}{ Optimal Cycles } \\
\hline $\begin{array}{c}\text { Metallothionein } \\
1 \mathrm{~A}, 1 \mathrm{~B}, 1 \mathrm{~F}, 1 \mathrm{G} \\
1 \mathrm{H}, 3,4\end{array}$ & $95^{\circ} \mathrm{C}$ for $2 \mathrm{~min}$ & $\begin{array}{l}95^{\circ} \mathrm{C} \text { for } 30 \mathrm{sec} \\
68^{\circ} \mathrm{C} \text { for } 30 \mathrm{sec}\end{array}$ & $\begin{array}{c}30,35 \text { and } \\
40 \text { cycles }\end{array}$ \\
\hline $\begin{array}{c}\text { Metallothionein } \\
1 \mathrm{E}, 1 \mathrm{X}, 2 \mathrm{~A}\end{array}$ & $95^{\circ} \mathrm{C}$ for $2 \min$ & $\begin{array}{l}95^{\circ} \mathrm{C} \text { for } 30 \mathrm{sec} \\
68^{\circ} \mathrm{C} \text { for } 30 \mathrm{sec}\end{array}$ & $\begin{array}{c}25,30 \text { and } \\
35 \text { cycles }\end{array}$ \\
\hline hsp 27 & $95^{\circ} \mathrm{C}$ for $2 \mathrm{~min}$ & $\begin{array}{l}95^{\circ} \mathrm{C} \text { for } 30 \mathrm{sec} \\
58^{\circ} \mathrm{C} \text { for } 30 \mathrm{sec}\end{array}$ & $\begin{array}{l}18,20 \text { and } \\
22 \text { cycles } \\
\end{array}$ \\
\hline hsp 60 & $95^{\circ} \mathrm{C}$ for $2 \mathrm{~min}$ & $\begin{array}{l}95^{\circ} \mathrm{C} \text { for } 30 \mathrm{sec} \\
58^{\circ} \mathrm{C} \text { for } 30 \mathrm{sec}\end{array}$ & $\begin{array}{c}25,30 \text { and } \\
35 \text { cycles }\end{array}$ \\
\hline $\begin{array}{c}\text { hsc } 70, \text { hsp } 70 \mathrm{~A}, \\
70 \mathrm{~B} \text { and } 70 \mathrm{C}\end{array}$ & $95^{\circ} \mathrm{C}$ for $2 \mathrm{~min}$ & $\begin{array}{l}95^{\circ} \mathrm{C} \text { for } 30 \mathrm{sec} \\
50^{\circ} \mathrm{C} \text { for } 30 \mathrm{sec}\end{array}$ & $\begin{array}{l}25,30 \text { and } \\
35 \text { cycles }\end{array}$ \\
\hline Clontec GAPDH & $95^{\circ} \mathrm{C}$ for $2 \min$ & $\begin{array}{l}95^{\circ} \mathrm{C} \text { for } 30 \mathrm{sec} \\
68^{\circ} \mathrm{C} \text { for } 30 \mathrm{sec}\end{array}$ & $\begin{array}{c}25,30 \text { and } \\
35 \text { cycles }\end{array}$ \\
\hline $\begin{array}{c}c-f o s, c-j u n \text { and } \\
c-m y c\end{array}$ & $95^{\circ} \mathrm{C}$ for $2 \min$ & $\begin{array}{l}95^{\circ} \mathrm{C} \text { for } 30 \mathrm{sec} \\
60^{\circ} \mathrm{C} \text { for } 30 \mathrm{sec} \\
72^{\circ} \mathrm{C} \text { for } 30 \mathrm{sec}\end{array}$ & $\begin{array}{c}23,25 \text { and } \\
28 \text { cycles }\end{array}$ \\
\hline
\end{tabular}




\section{APPENDIX C}

WESTERN AND DOT BLOT REAGENTS 


\section{X SDS LYSIS BUFFER}

Two gram of sodium dodecal sulfate (SDS, Fisher Scientific, Cat No. BP166-500) was dissolved in $100 \mathrm{ml}$ of the $50 \mathrm{mM}$ Tris-Cl solution (pH 6.8) prepared by dissolving Tris base (Fisher Scientific, Cat No. BP152-5) in distilled water and adjusting its $\mathrm{pH}$ with concentrated $\mathrm{HCl}$. The mixture was stirred until the $2 \%$ SDS was completely dissolved.

\section{COMPONENTS OF POLYACRYLIMIDE GELS}

\begin{tabular}{|c|c|c||}
\hline Reagent & $\begin{array}{c}12.5 \% \text { SDS } \\
\text { Resolving Gel } \\
(1.5 \mathrm{~mm} \text { thick })\end{array}$ & $\begin{array}{c}4 \% \text { SDS } \\
\text { Stacking Gel } \\
(1.5 \mathrm{~mm} \text { thick })\end{array}$ \\
\hline \hline $\mathrm{dH} \mathrm{H}_{2} \mathrm{O}$ & $2.55 \mathrm{ml}$ & $2.44 \mathrm{ml}$ \\
\hline $1.5 \mathrm{M}$ Tris-Cl $(\mathrm{pH} 8.8)$ & $2 \mathrm{ml}$ & - \\
\hline \hline $0.5 \mathrm{M}$ Tris-Cl $(\mathrm{pH} 6.8)$ & - & $1 \mathrm{ml}$ \\
\hline $10 \%$ SDS solution & $80: \mathrm{l}$ & $40: \mathrm{l}$ \\
\hline $\begin{array}{c}30 \% \text { Bis Acrylamide } \\
\text { (BioRad Laboratories, } \\
\text { Cat\#161-0158) }\end{array}$ & $3.33 \mathrm{ml}$ & $20: \mathrm{ml}$ \\
\hline \begin{tabular}{c}
$10 \%$ APS \\
\hline $\begin{array}{c}\text { TEMED } \\
\text { BioRad Laboratories, } \\
\text { Cat\#161-0801) }\end{array}$
\end{tabular} & $40: \mathrm{l}$ & $4: \mathrm{l}$ \\
\hline
\end{tabular}

\section{COMPONENTS OF 4X SDS LOADING DYE}

$200 \mathrm{mM}$ Tris-Cl (pH 6.8)

400 mM dithiothreitol (Sigma, Cat No.150460)

8\% SDS (Fisher Scientific, Cat No. BP166-500)

0.4\% bromophenol blue (BioRad, Cat No. 161-0404)

$40 \%$ glycerol. 


\section{TRANSFER BUFFER}

$2.9 \mathrm{~g}$ of glycine (Fisher Scientific, Cat No. BP381-1)

$5.8 \mathrm{~g}$ of Tris base (Fisher Scientific, Cat No. BP152-5)

$0.37 \mathrm{~g}$ of SDS

$200 \mathrm{ml}$ of $100 \%$ methanol (Fisher Scientific, Cat No. A452-4)

$\mathrm{dH}_{2} \mathrm{O}$ to make 1 liter $(\mathrm{pH} 8.3)$.

\section{ANTIBODIES FOR THE DETECTION OF HEAT SHOCK PROTEINS (HSP)}

\section{PRIMARY ANTIBODIES}

Mouse anti-hsp 27 antibody, 1:500 dilution in $45 \mathrm{ml}$

450 : I of $10 \%$ bovine serum albumin (BSA, Fischer Scientific, Fair Lawn, NJ, USA. Cat No. BP1605-100), 225 :I of $4 \% \mathrm{NaN}_{3}, 45$ :I of Anti-hsp 27 (StressGen, Cat No. STM-800), 1x PBS to $45 \mathrm{ml}$.

Anti-hsp 60 antibody, 1:2000 dilution in $50 \mathrm{ml}$ 450 : I of $10 \%$ BSA, 225 : I of $4 \% \mathrm{NaN}_{3}, 25$ : I of Anti-hsp 60 (StressGen, Cat No. STM-806), 1x PBS to $50 \mathrm{ml}$.

Rat anti-hsc 70 antibody, 1:2000 dilution in $45 \mathrm{ml}$ $450:$ I of $10 \%$ BSA, 225 : I of $4 \% \mathrm{NaN}_{3}, 22.5$ : I of Anti-hsc 70 (StressGen, Cat No. SPA-815), 1x PBS to $45 \mathrm{ml}$.

Mouse anti-hsp 70 antibody, 1:2000 dilution in $50 \mathrm{ml}$ $1.5 \mathrm{~g}$ of condensed milk (5\%), 225 : I of $4 \% \mathrm{NaN}_{3}, 25$ : I Tween-20 (0.05\%), 25 : I of Anti-hsp 70 (StressGen, Cat No. STM-810), 1x PBS to $50 \mathrm{ml}$. 


\section{SECONDARY ANTIBODIES}

\section{Anti-Mouse antibody 1:2000 dilution in $45 \mathrm{ml}$}

450 : I of $10 \%$ BSA (0.1\%), 225 : I of $4 \% \mathrm{NaN}_{3}, 22.5$ : I of Anti-Mouse antibody (1 : g/ml) (Promega Corp., Madison, WI, USA. Cat No. S372B), 1x PBS to $45 \mathrm{ml}$.

\section{Anti-Rat antibody 1:2000 dilution in $45 \mathrm{ml}$}

450 : I of $10 \% \operatorname{BSA}(0.1 \%), 225:$ I of $4 \% \mathrm{NaN}_{3}, 22.5:$ I of $1: \mathrm{g} /$ : I Anti-Rat antibody (Promega Corp., Cat No. S3831), 1x PBS to $45 \mathrm{ml}$.

\section{ANTIBODIES FOR THE DETECTION OF METALLOTHIONEIN PROTEINS MT-I/II, E9 Antibody (1:100 dilution), Primary Antibody}

$4.5 \mathrm{ml}$ of $10 \% \mathrm{BSA}, 225$ : I of $4 \% \mathrm{NaN}_{3}, 450$ : I of E9 MT-I/II antibody (DAKO Corp., Carpinteria, CA, Cat No. M0639), 1x PBS to $45 \mathrm{ml}$.

\section{Anti-Mouse IgG Antibody (1:500 dilution), Secondary Antibody}

$1.8 \mathrm{ml}$ of $10 \%$ BSA, 225 : I of $4 \% \mathrm{NaN}_{3}, 90$ : I of anti-mouse antibody $(1: \mathrm{g} / \mathrm{ml})$ (Promega, Cat No. S372B), 1x PBS to $45 \mathrm{ml}$.

\section{MT-3 Polyclonal Antibody (1:100 dilution), Primary Antibody}

$9 \mathrm{ml}$ of $10 \%$ BSA, 225 : I of $4 \% \mathrm{NaN}_{3}, 112.5$ : I of $2: \mathrm{g} /:$ I metallothionein 3 antirabbit antibody, 1x PBS to $45 \mathrm{ml}$. The synthesis of the metallothionein 3 antirabbit antibody has been described previously (Garrett, et al. (1999) Toxicol Lett. 105(3):207-214). New Zealand White rabbits were immunized with a peptide (GGEAAEAEAEKC) corresponding to MT-3 amino acids 53-64 that contain the MT-3 unique amino acid insert. The dodeca-peptide was conjugated through the C-terminal sulfhydryl group to keyhole limpet hemocyanine using maleimidobenzoyl-N-hydrosuccinimide ester. The MT-3 antibody was affinitypurified using the dodecapeptide linked to a SulfoLink gel (Pierce, Rockford, IL) 
through the C-terminal cysteine residue. The MT-3 antibody has been shown to selectively bind to both tissue sections (immunohistochemical localization) and protein extracts (Western blot analysis) of human brain.

Anti-Rabbit Antibody (1:500 dilution), Secondary Antibody

$1.8:$ I of $10 \%$ BSA, $225:$ I of $4 \% \mathrm{NaN}_{3}, 90:$ I of $1: \mathrm{g} / \mathrm{ml}$ anti-rabbit antibody (Promega, Cat No. S3831), 1x PBS to $45 \mathrm{ml}$.

\section{ALKALINE PHOSPHATASE BUFFER}

Alkaline phosphatase buffer for use with the Vectastain ABC-AP detection kit (Vector Laboratories, Burlingame, CA, USA) was a solution of $100 \mathrm{mM}$ Tris- $\mathrm{HCl}$ at $\mathrm{pH}$ 8.2. 


\title{
CURRICULUM VITAE
}

\author{
Name : Doyeob Kim \\ Date of birth : May 20, 1968 \\ Address : 6101 Chestnut Hill APT, Morgantown, WV 26505 \\ Tel : (H) 304-598-5647, (O) 304-293-1616 \\ E-mail : dkim5@wvu.edu
}

\section{Education}

1986 - 1990 : Bachelor, Dept. of biology, Yonsei University, Seoul, Korea 1995 - 1997 : Master of Science, Dept. of biology (Molecular Microbiology), Yonsei University, Seoul, Korea. Thesis : Mechanism of quinolone resistance in methylotrophic bacteria

1998 - Present (2002) : Ph. D. Graduate student (research assistant) at the dept. of Genetics in West Virginia University.

Research title : Expression and function of metallothionein isoform 3 (MT-3) in human proximal tubule cells (HPT). MT-3 is basally expressed and induced by metals, such as $\mathrm{Zn}$ and $\mathrm{Cd}$ in HPT using RT-PCR and immuno-blot techniques, and it is involved in Cd resistance in the cell by the use of antisense oligos. When MT-3 is transfected into the immortalized human kidney cell (HK-2), all the clone cells express dome formation (biomarker for HPT cell differentiation) in vitro. Now, the technique of site directed mutagenesis is being used to see which domain of MT-3 protein is involved in dome formation in HK-2.

\section{Experience}

1990 - present (2002) : Senior Researcher at Pharmaceutical Screening Center in Korea Research Institute of Chemical Technology. The institute sent me to study in US for the doctoral courses in 1998.

\section{Publications}

\section{(A) Papers}

1. D Kim, S H Garrett, M A Sens, S Somji and D A Sens. Metallothionein isoform 3 and proximal tubule vectorial active transport. Kidney International. 2002. 61 (2) : 464-472.

2. S H Garrett, V Phillips, S Somji, M A Sens, R Dutta, S Park, D Kim, and D A Sens. Transient induction of metallothionein isoform 3 (MT-3), c-fos, c-jun and c-myc in human proximal tubule cells exposed to cadmium. Toxicol. Lett. 2002. 126 (1) : 69-80. 
3. D Kim, S Somji, S H Garrett, M A Sens and D A Sens. Expression of hsp 27, hsp 60 , hsc 70 , hsp 70 by immortalized human proximal tubule cells (HK-2) following exposure to heat shock, sodium arsenite or cadmium chloride. Journal of Toxicology and Environmental Health. 2001. 63 (7) : 475-493.

4. D Kim, IS Lee, JH Jung, CO Lee and SU Choi. Psasmmaplin A, a Natural Phenolic Compound, has Inhibitory Effect on Human Topoisomerase II and is Cytotoxic to Cancer Cells. Anticancer Research. 1999.19:4085-4090.

5. D Kim, IS Lee, JH Jung and SI Yang. Psammaplin A, a natural bromotyrosine derivative from a sponge, possesses the antibacterial activity against methicillin-resistant Staphylococcus aureus and the DNA gyrase-inhibitory activity. Archives of Pharmacal Research. 1999. 22:1 25-9

6. K Choi, J Cha, A Pae, Y Cho, Y Kim, M Chang, S Park, S Park, D Kim et al. Studies on Novel 3-Isoxazolylvinylcephalosporins: II. Synthesis and Biological Activity of 7-[2-(2-Aminothiazol-4-yl)-2-hydroxyiminoacetamido] Derivatives. J Antibiotics (Japan). 1998. 51: 1122-1125

7. MS Cho, D Kim, JY Kong and SI Yang. Ciprofloxacin resistance by altered gyrase and drug efflux system in Pseudomonas aeruginosa. Archives of Pharmacal Research. 1995. 18:173-178.

8. HK Chon, HJ Kim, EK Yum, SY Cho, D Kim, and SI Yang. Studies on the mechanism of action of the gastric $\mathrm{H}^{+}+\mathrm{K}^{+}$-ATPase inhibitor $\mathrm{KH} 3218$. The Journal of Applied Pharmacology. 1995. 3:205-209.

9. KL Seo, D Kim, SI Yang. Studies on the antibacterial effect of wasabi extracts. Korean Journal of Nutrition. 1995. 28:1073-77.

10. CH Oh, ER Woo, S Seo, SY Hong, KH Nam, D Kim, and JH Cho. A new series of carbapenem with 5'-aminomethylene substituted pyrrolidin-3'-ylthio group at C-2 position. The Korean Journal of Medicinal Chemistry. 1994. 4:2634.

\section{(B) Abstracts}

1. Metallothionein isoform $3(\mathrm{MT}-3)$ and proximal tubule active transport. Society of Toxicology. 2002.

2. The expression of metallothionein in an immortalized human proximal tubule cell line, HK-2, and normal human proximal tubule cells in response to cadmium and arsenite exposure. Society of Toxicology. 2001.

3. Expression of hsp 27, hsp 60, hsc 70 and hsp 70 by immortalized human proximal tubule cells (HK-2) following exposure to heat shock, sodium arsenite or cadmium chloride. Society of Toxicology. 2001.

4. Comparison of the stress response between cultured human proximal tubule cells and the derived cell line HK-2. Society of Toxicology. 2000. 
5. Mechanism of quinolone resistance in methylotrophic bacteria. Korean Society of Microbiology. 1998.

6. Inhibitory effect of Pach B against DNA topoisomerases. Korean Society of Pharmacology. 1997.

7. Sensitizing effects on cancer cells to topoisomerase inhibitors by catechins. Korean Society of Pharmacology. 1997.

8. Inhibitory activity of tribactam against bacterial beta-lactamase. Korean Society of Pharmacology. 1996.

9. Studies on the antimicrobial mechanism of Pach B, a natural product. Korean Society of Pharmacology. 1995.

10. Studies on urease from Helicobacter pylori: Cytotoxicity to several human cell lines. Korean Society of Microbiology. 1994.

11. Mechanisms of quinolone resistance in Pseudomonas aeruginosa. Korean Society of Pharmacology. 1994.

12. Large scale production of new antifungal compound, KRF-001 by continuous culture. Korean Society of Biotechnology. 1990. (Oral presentation)

\section{(C) Patent}

1. Process for preparing coated microbial pesticides and pesticides produced therefrom. 1993. United State Patent. Patent No. 5273749.

2. Bioactive organic fertilizer and its producing method. Korean Patent. 1994. Patent No. 089652.

\section{Honors}

1. Graduate Student Travel Award for the 2002 Annual Meeting of the Society of Toxicology at Nashville, USA.

2. West Virginia University Graduate Assistantship, 1998-2002.

3. An award from the Minister of Science and Technology in Korea on the synthesis and screening of new quinolone antibiotics. 1993. 